\title{
Depois de \\ junho a paz \\ será total
}

\section{ÚLTIMO CAPÍTULO DO LIVRO}

(1) novo tempo do mundo 


\section{Depois de junho a paz será total}

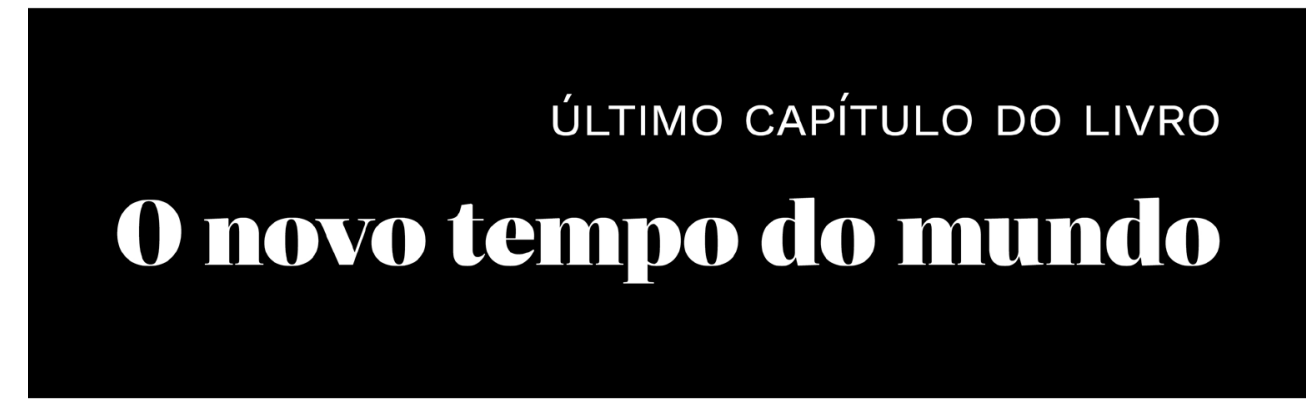

2014 
A coleção é organizada em sete categorias e três subcoleções, com diferentes tipologias documentais e formatos de arquivos:

Categorias: Filosofia; Política; Estética; Arquitetura e Cidades; Artes Plásticas; Crítica da Cultura e Trajetórias. Cada categoria adota uma cor específica aplicada na capa do e-book.

\section{Subcoleções:}

E-books: livros, capítulos, prefácios, artigos e entrevistas (em formatos PDF, EPUB e MOBI/Kindle) - com obras em português, inglês, espanhol, italiano e francês.

Documentos: matérias de jornal, fotos e documentos históricos (em formatos

PDF e JPEG)

Mídia: vídeos ou áudios de palestras, aulas e debates (em formatos MP3 e MP4) associados a um canal da coleção no YouTube.

Coordenação editorial: Pedro Fiori Arantes

Projeto Gráfico: Paula Astiz

Dados Internacionais de Catalogação na Publicação (CIP)

Arantes, Paulo Eduardo, 1942--

Depois de junho a paz será total [recurso eletrônico] / Paulo

Eduardo Arantes. -- São Paulo: [s.n], 2021.

ePUB. - (Coleção sentimento da dialética / coordenação Pedro

Fiori Arantes)

\section{ISBN 978-65-00-20127-7}

1. Brasil - política e governo - 2011-2016. 2. Movimentos de protesto - História - Séc. XXI - Brasil. 3. Manifestações públicas

- História - Sec. XXI - Brasil. 4. Conflito social - Brasil. l. Arantes,

Pedro Fiori, 1974-. II. Título. III. Série,

CDD 303.620981

Elaborado por Cristiane de Melo Shirayama - CRB 8/7610

DOI: https://doi.org/10.34024/9786500201277

\section{(c) $(1) \Theta$}

Esta obra tem licença Creative Commons internacional 4.0

http://creativecommons.org/licenses/by-nc-nd/4.0/

\section{Publicado originalmente como capítulo em:}

Paulo Eduardo Arantes. O novo tempo do mundo. São Paulo, Editora Boitempo, 2014

\section{Sentimento da Dialética}

UM ENCONTRO COM A OBRA DE OTÍLIA E PAULO ARANTES
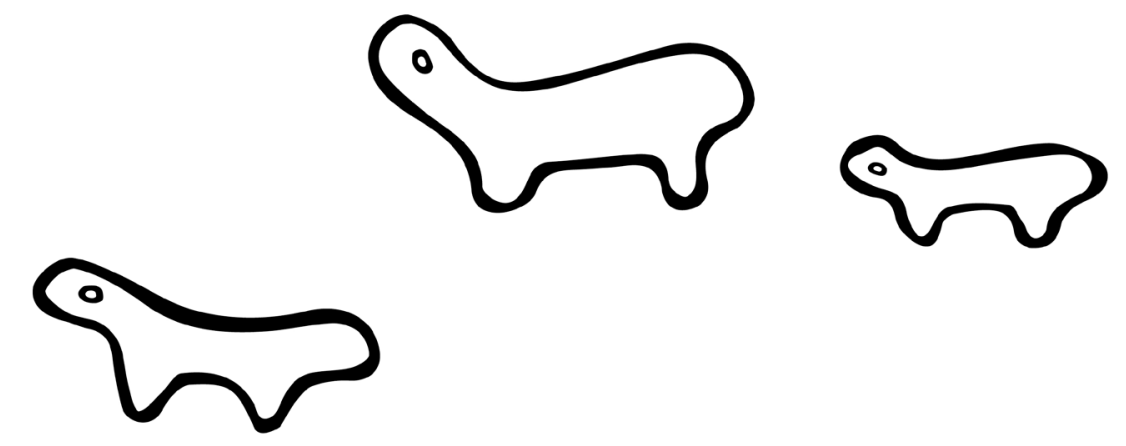


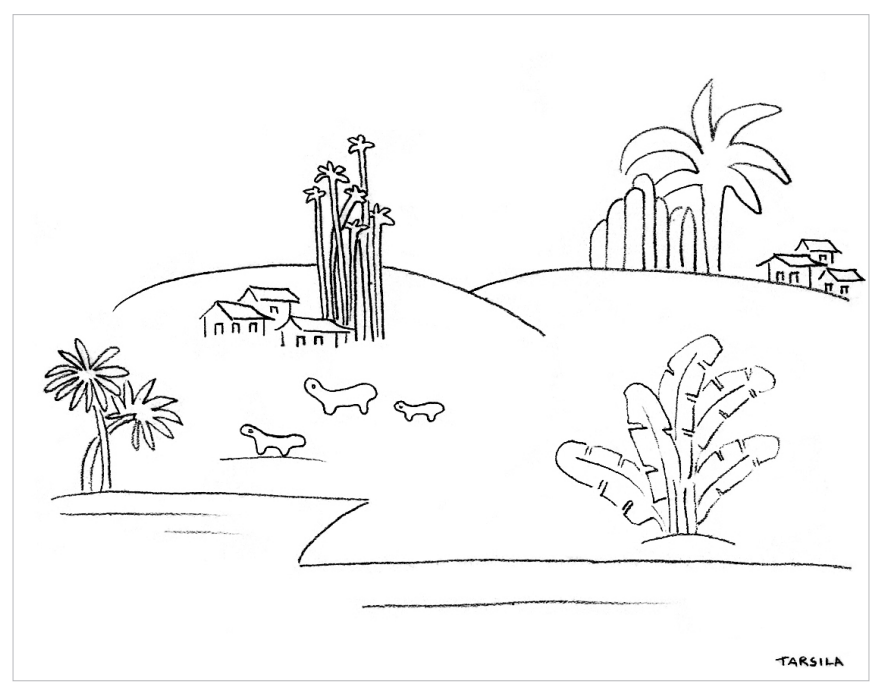

Tarsila do Amaral. Paisagem antropofágica - I, 1929 c - lápis s/ papel, 18,0 x 22,9 cm. Coleção Mário de Andrade. Coleção de Artes Visuais do Instituto de Estudos Brasileiros USP. Reprodução gentilmente cedida pela família e IEB USP.

O novo tempo do mundo exige dos intelectuais responsabilidades que lhes são intrínsecas: a de tornar a força das ideias parte do movimento de entendimento e transformação do mundo. Os filósofos Otília Beatriz Fiori Arantes e Paulo Eduardo Arantes cumprem, juntos, há mais de 50 anos, a tarefa da crítica como intelectuais públicos atuantes, transitando entre diversas áreas das humanidades e da cultura, em diferentes audiências e espaços de formação. A coleção Sentimento da Dialética é um lugar de encontro com a obra de Otília e Paulo Arantes e reafirma o sentido coletivo da sua produção intelectual, reunida e editada em livros digitais gratuitos. É um encontro da sua obra com um público cada vez mais amplo, plural e popular, formado por estudantes e novos intelectuais e ativistas brasileiros. É também um encontro da sua obra com o movimento contemporâneo em defesa do conhecimento livre e desmercantilizado, na produção do comum e de um outro mundo possível. 
$11 \quad$ Nota Introdutória

15

\section{DEPOIS DE JUNHO A PAZ SERÁ TOTAI}

1.

2.

3.

4.

5.

6.

Postscriptum

Aula pública: Tarifa zero e mobilização popular 


\section{Nota Introdutória}

\section{Isabel Loureiro}

Depois de junho a paz será total é o título irônico do tour de force que encerra a nossa viagem e que procura dar conta do vínculo entre pacificação e insurgência. Pulverizando os clichês propagados à direita e à esquerda - "baderna" de rua protagonizada por vândalos a serem devidamente dedetizados pelas forças da ordem, ou esquerdismo infantil de uma juventude desorganizada, sem direção, e que portanto dará em nada-, Paulo Arantes vai rastreando, naliteratura recente sobre as classes populares urbanas no Brasil e em publicações de protagonistas dos eventos, ideias que lhe permitam construir hipóteses sobre a genealogia dos acontecimentos de junho de 2013. Dessa maneira, leva a cabo a interpretação mais original desses eventos até agora.

Se pusermos na panela de pressão brasileira os seguintes ingredientes, quase todos indigestos: o Programa de Pacificação das Favelas no Rio de Janeiro com suas UPPs, na verdade uma estratégia de guerra; a violência policial contra os moradores das periferias urbanas; as remoções forçadas exigidas pelos megaeventos; as políticas públicas que, ao incitar o empreendedorismo dos pobres, se, por um lado, canalizam sua energia para uma atividade governável, por outro, criam um sedimento reivindicativo à espreita para explodir; as lutas pela cidade, levadas a cabo por uma geração de "cidadãos insurgentes" exigindo a democratização do solo urbano; a "agonia do trabalho descartável, 
mostrando que o capitalismo como religião em sua forma contemporânea tornou-se um espantoso e interminável 'ritual de sofrimento"; as revoltas populares pelo transporte público; a síndrome da participação cidadã sem poder, etc. todos temas analisados pelo Autor-, desconfiamos que esse conjunto de fenômenos faz sistema e explica, quem sabe, a "nova insurgência profanatória" que explodiu nas ruas em junho de 2013. Não é possível retomar aqui passo a passo a exposição até chegar à atuação do Movimento Passe Livre (MPL), responsável pelo desencadeamento daqueles eventos memoráveis. Basta dizer que o movimento foi vitorioso graças a sua lucidez tática e estratégica-em forte contraste com a inabilidade política do prefeito e do governador. Os jovens (insurgentes?) do MPL souberam aliar o foco "reformista" numa única demanda, a redução de 20 centavos na tarifa, com uma exigência anticapitalista de desmercantilização da vida, a tarifa zero. Assim sendo, apresentaram um novo modelo - ainda que seja uma "herança sem receita" - para as lutas sociais no Brasil, ao mesmo tempo em que afrontaram a esquerda oficial, entorpecida pela Realpolitik.

Paulo Arantes - assim como há exatos 50 anos o Marcuse de $\mathrm{O}$ homem unidimensional - é visto frequentemente como adepto da crítica pela crítica; tal como Mefistófeles, o espírito que sempre nega, teria ficado preso ao pessimismo de uma sociedade sem oposição; ao não apresentar alternativas, só levaria à paralisia, etc. O leitor atento verá que, muito pelo contrário, a crítica radical não se esgota nela mesma, mas cria o sentimento da urgência necessário à luta. No mundo da racionalidade neoliberal - em que a lógica do mercado se autonomiza e se estende para fora da esfera mercantil, estruturando a ação dos governantes, assim como a dos próprios governados no mais íntimo da sua subjetividade - a ideia de negação da negação ficou obsoleta, Marcuse dixit, para escândalo dos marxistas ortodoxos que teimam em não perceber que o realejo da dialética já não garante a superação imanente das contradições atuais numa etapa superior. Paulo Arantes concorda. De onde viria a ruptura com o sistema absurdo da acumulação pela acumulação quando as tecnologias de controle social, tudo leva a crer, produziram um "indivíduo absolutamente governável" e isso com sua própria e resoluta colaboração? Como romper com a pretensa normalidade governamental que reduz a política a uma perspectiva contábil?

O que os insurgentes de junho nos ensinam, nas palavras de John Holloway citadas pelo Autor, é que "Não faz mais sentido falar em paciência como uma virtude revolucionária ou falar sobre 'revolução futura'. Que futuro? Precisamos da revolução agora, aqui e agora. Tão absurdo, tão necessário. Tão óbvio". Hoje, a “utopia real” consiste na Grande Recusa desse sistema de normas, valores, práticas que mercantilizam todas as dimensões da vida, infringindo sofrimento e humilhação aos de baixo, e ao mesmo tempo temor de arriscar a ruptura com o eterno retorno do mesmo. Encarar esse estado de coisas e dar um passo adiante é a tarefa da nova geração. Que abriu uma porta em junho de 2013.

Um vento de utopia sopra em várias passagens do livro, mas vou me ater ao trecho final, quando Paulo comenta um texto da socióloga Regina Magalhães de Souza em que ela resume sua experiência de professora de sociologia numa dessas universidades particulares que vendem diplomas como se fossem bananas. A maioria dos alunos, trabalhadores pobres habitantes das periferias, vão descobrindo aos poucos que, em vez de serem apenas indivíduos atomizados lutando às cotoveladas por seus interesses próprios, fazem parte de uma coisa chamada "sociedade", que esta "lhes exige muito, mas não lhes oferece as condições de realizarem o que foi exigido". 
Ou seja, começaram a pensar e a fazer ligações entre suas experiências individuais e o contexto histórico e social. O que só foi possível porque, de alguma maneira, estavam fora da rede de integração pelo consumo, pelos movimentos sociais, partidos, protagonismo juvenil. A professora reconheceu muitos deles nas ruas de junho. Isso lhe dá o insight de que "a massa dos manifestantes era de indivíduos desamparados e sem discurso, mas que por isso mesmo foram capazes de perceber o caráter subalterno e de segunda categoria de sua inserção na sociedade, no mercado de trabalho, no mercado de consumo, no nível superior de ensino, na vida da metrópole [...]. [Eles] descobriram que coletivamente podem manifestar-se contra uma sociedade que tudo exige e nada cumpre". Para usarmos os termos de Silvia Viana, eles começaram a recusar as "porradas da vida", e por isso são imprescindíveis para a tarefa política da nova geração. Paulo Arantes dedica seu livro "ao sangue bom que há treze anos circula nas noites de quarta" - os jovens estudantes que há mais de uma década frequentam o seminário livre animado por ele na Faculdade de Filosofia da USP. Ali fervilham ideias sobre as "coisas novas e ruins" do tempo presente, o Brasil em primeiro lugar. Incorporadas por ele à sua reflexão, essas ideias do contra, ao insuflar novo alento nas energias utópicas eclipsadas há muito, ajudam a manter viva a chama da redenção.

Isabel Loureiro é Doutora em Filosofia. Professora aposentada da UNESP. Publicou, entre outros, livros sobre Rosa Luxemburgo e sobre a Revolução alemã.

Publicado originalmente como resenha na Revista do IEB USP, São Paulo, n. 59, p. 389-396, dez. 2014

\section{DEPOIS DE JUNHO A PAZ SERÁ TOTAL}

1.

Durante alguns meses, o rescaldo de Junho parecia não ter fim na cidade do Rio de Janeiro. Como a onda "coxinha" refluíra, as ruas voltaram a ser ocupadas exclusivamente pelos manifestantes da primeira hora, cujo fôlego continuava a surpreender. Quase diários, os atos se estenderam pelo menos até setembro, e um pouco além, como o explosivo 15 de outubro (exatos dez dias depois em São Paulo, foi a vez de um coronel da PM sentir na pele a sensação térmica de público-alvo, para recorrer ao jargão no emprego do qual convergem faz tempo governantes, empresas, ONGs e veteranos de movimentos sociais históricos). Pois foi nessa atmosfera sobrecarregada por meses de lacrimogênio, pimenta e borracha - para nos restringirmos aos ingredientes básicos do coquetel servido ao supracitado público-alvo -, que foi se armando um raciocínio enviesado e não menos tóxico do que a mistura de gás e ordem que respiramos desde junho, pelo menos com uma intensidade e frequência inéditas para o alvo da vez. Seja como for, o argumento estava no ar quando circulou na cidade um manifesto de apoio ao AfroReggae e seu coordenador José Júnior, “Deixem o Rio em Paz”. 
Um punhado de notáveis e celebridades puxava um arrastão de "empresários, médicos, executivos, economistas, publicitários, antropólogos, escritores, músicos, jornalistas e policiais" - na divertida e pitoresca enumeração de um apoiador entusiasta que, no entanto, se esqueceu de comemorar a ausência de políticos - em solidariedade à ONG ultrapremiada cujas instalações no Complexo do Alemão sofreram vários e mal explicados atentados e, seu fundador, outras tantas ameaças de morte. O AfroReggae dispensa apresentações, bem como a personalidade carismática de seu líder. Relembro apenas que ao completar vinte anos exportando sua tecnologia social para o resto do Brasil, e do mundo que foi se periferizando, a marca AfroReggae é também o resumo conclusivo de uma trajetória de unanimidade em torno de iniciativas que surgiram na esteira da Ação da Cidadania, inaugurada por Betinho em 1993, não por acaso no mesmo ano de nascimento de uma iniciativa complementar chamada Viva Rio. E, é claro, no meio do caminho, as chacinas consecutivas da Candelária e Vigário Geral, respectivamente em julho e agosto do mesmo 1993. Um ano depois, o jornalista Zuenir Ventura publicaria a crônica daquelas campanhas que sob o amplo guarda-chuva da Paz já costuravam no mesmo saco Fome e Segurança. ${ }^{1}$ Creio que pela primeira vez os vestidos de branco botavam o bloco na rua. Uma virada e tanto: a bandeira branca voltava a ser uma bandeira de guerra, só que desta vez, nas palavras de um dos idealizadores da campanha - lembrando que antes de ser filantrópica, publicitária ou eleitoral, juntando movi-

1. Estou me referindo, como o leitor deve ter adivinhado, a Cidade partida (São Paulo: Cia das Letras, 1994). Minha edição é a nona reimpressão do ano 2000. mento e efeito público de choque, e sempre planejada por um estado maior, uma "campanha" designava originalmente uma temporada coordenada de operações bélicas -, tratava-se de declarar uma "guerra ao contrário", contra a violência e pela paz. Entrava-se na violência pela porta da não-violência, como também se proclamava ${ }^{2}$. Vinte anos depois, como nos tempos ansiosos em que pipocavam campanhas do tipo Rio Mania, Se Liga Rio, Caminhada Pela Vida e Pela Paz etc., o exorcismo da cidade dividida, a exortação de que o Rio tem que ser um só, como se dizia naquele longínquo ano de 1993, abalado pelas chacinas gêmeas, ressurgiu com força. Como a guerra sem fim contemporânea, a paz também parece não ter limites.

Por certo não é a primeira vez que Zé Júnior é ameaçado de morte. Sendo por excelência um "mediador de guerra em favela", como ele mesmo costuma se apresentar, recordando os primeiros passos de sua carreira, é natural que colecione ressentimentos de ambos os lados da linha de sombra em que sua condição anfíbia o condena a transitar. ${ }^{3}$ Desarmar conflitos violentos, casando-os com projetos sociais, é uma operação ainda mais arriscada pouco importa a garantia dos patrocínios corporativos por uma particular escolha estratégica: "Só entramos em área não pacificada, só montamos núcleos em área de conflito”. Durante muito tempo, quando subia o morro para negociar conflitos, não via nenhuma ONG ou movimento social ao seu lado; hoje, capacita policiais militares - que antes chegavam fardados e armados nas escolas e favelas - em grafite, streetdance, circo, etc. Sinal este último de

2. Como relata Zuenir (Op. cit., p.90).

3. “O AfroReggae só atua onde ninguém quer atuar.” Entrevista de Eduardo Sá com Zé Júnior. Caros Amigos, nº 186, Setembro de 2012. 
que quando a maré virou a favor da reunião administrada das duas metades antagônicas da cidade partida, retrospectivamente realçou ainda mais a tecnologia pioneira do AfroReggae. No limite, a peregrinação a Medellin era dispensável, modelo do qual os governos locais copiaram quando muito o teleférico, mesmo assim inexequível sem os serviços de relações públicas promovidas por Zé Junior: "A obra do teleférico do Complexo do Alemão, quem mediou para traficante não destruir em 2008 fui eu. Eu sentei com o Tota, que era o todo poderoso do Comando Vermelho, e com o Luciano Pezão (vice-governador) e não foi dado um real para traficante". ${ }^{4}$ Deixem o AfroReggae e seu principal animador em paz - venham de onde vierem as ameaças e os atentados, do crime ou da banda podre da polícia, os suspeitos de sempre-, quer dizer: não arranhem o simbolismo do pioneiro dispositivo pacificador montado por Zé Júnior. Mexeu com ele, mexeu com o Programa de Pacificação das Favelas, do qual as Unidades de Polícia Pacificadora (UPP), como se sabe, constituem a joia da coroa, de onde irradiam as mais variadas políticas de gestão dos territórios conquistados ou liberados, como se queira. Tirante a declaração inicial de natural solidariedade, o Manifesto veio apenas relembrar com ênfase redobrada que "a Pacificação é um patrimônio do Rio de Janeiro". Mas então quem o ameaça? As facções retraídas? O aparato coercitivo que o assegura, tantos Amarildos quantos forem os efeitos colaterais necessários e inevitáveis? E morador em desacordo, eventualmente inconformado com o novo estilo das abordagens, que se saiba ainda não dá tiro.

4. Ibidem, pp.41-42. Para um balanço do deslumbramento dos políticos brasileiros que visitam Medellin, a reportagem de Daniela Pinheiro ("Mano Dura e obras públicas”, Piauí, Novembro de 2007, pp.46-53)
Aqui entramos nós, quer dizer, o ar do novo tempo cristalizado na percepção arrevesada que estamos tentando identificar. Quem afinal ameaça a continuidade daquela política, à qual se costuma atribuir a onda recente de investimentos, grandes eventos, turismo, emprego abundante etc.? A máquina carioca de crescimento urbano em princípio não funcionaria a pleno vapor não fosse o clima de paz instaurado graças àquele cinturão de segurança. Acresce que se trata de um consenso arduamente costurado desde os tais anos fundadores que teriam revelado uma cidade fraturada e à beira do abismo, consenso solidarizando governantes e governados, todas as classes confundidas, num sentimento comum de crise emergencial pedindo salvação drástica. Fora os usuais energúmenos do contra, quem ousaria represar ou desviar esse rio de paz e prosperidade que está passando em nossas vidas? Mesmo que dê para desconfiar, a surpresa do curto-circuito não é menos dissonante. O quebra-quebra de Junho, é claro. A política do quebra-quebra que brotou das ruas sabe se lá por quais vias tortas e impenetráveis e a escalada que ela prenuncia. Compreende-se a rejeição que se conhece, espantoso mesmo seria o contrário. O que realmente intriga - não dá para acrescentar e assusta, pois a atual normalidade coercitiva já é por definição assustadora - é o traçado bizarro que liga os pontos, a vida serena nos territórios pacificados num extremo, e o som e a fúria das ruas de Junho, no outro. De onde teria surgido a ideia de que cedo ou tarde toda aquela energia sem eira nem beira inundaria precisamente aqueles santuários? Neste ponto, a linha de raciocínio faz um rodeio indutivo pela demanda clássica cui bono? Com certeza o tráfico, beneficiário direto dos tumultos que se seguiram à revoada lírica de Junho e que já estaria salivando por conta. En- 
tão é isso: depois de Junho o tiroteio voltou, e mais, não é mero acaso que o retorno da pancadaria nas ruas do Rio coincida com uma inflexão na curva ascendente da criminalidade. Chegou-se a dizer que usuários e repassadores de drogas estavam sendo pagos para engrossar o caldo da novíssima cultura da depredação. Algum sexto sentido punitivo por certo desconfiou que tanta e inusitada energia no confronto deveria brotar de uma fonte igualmente suspeita da mesma ordem que o princípio ativo das substâncias ilícitas comercializadas no varejo asfixiado pelo clima de paz social reinante na cidade desde a inauguração do programa redentor.

É claro, o amálgama acerca dos beneficiários diretos da explosão de violência política nas ruas do Rio nas semanas que se seguiram à efêmera coreografia pacifista (lembrando que os tais manifestantes pacíficos bateram sem dó nem piedade nos vermelhos), não chega a concluir que a intenção original era essa, "acabar com o sossego dos moradores das favelas ocupadas pelas UPPs". Noutros tempos, o argumento do aliado objetivo costumava ser infalível. Como respira, tal argumento, uma inconfundível e longínqua memória política de alianças sempre sonhadas, porque no fundo impossíveis, chegou-se até mesmo a alegar que sair por aí quebrando tudo acabaria por reforçar o moral dos traficantes os quais, uma vez "recuperado o espírito de luta" (quem diria!), tratariam de reaver o domínio territorial perdido, reascendendo a guerra com o pavio de Junho. É curioso que não tenha ainda ocorrido a fantasia, na montagem do espantalho, de que o contágio agora se propagaria na mão inversa - do morro ao asfalto - porém nivelando por baixo, no marco zero da degradação, pois como até os especialistas teriam obrigação de saber, a crise barbariza por igual, fragmentando ainda mais os comandos da droga, cada vez mais irracionais e autodestrutivos. Deixando de "representar uma alternativa econômica, ainda que perigosa e ilegal, tendem a se tornar núcleos de pura violência"5. É questão de tempo, se é que o referido amálgama já não tocou esse fundo negro do poço. Mas continuemos com a assombração se desenhando na névoa de enxofre do dia seguinte à ruptura de Junho - é por esses e outros fantasmas que o país não voltará mais a ser o mesmo. Essa ligação à primeira vista paranoica de pontos tão díspares também está acentuando outra ameaça, e de novo o mau exemplo vem da desobediência das ruas. É raro, mas de vez enquanto a mídia deixa vazar a notícia de que as comunidades pacificadas reclamam dos novos usos e costumes dos pacificadores. ${ }^{6} \mathrm{E}$ se a notícia se

5. Como lembrado por Marcos Barreira no capítulo sobre o nexo entre reestruturação urbana e violência na cidade do Rio de Janeiro, "Cidade Olímpica", no livro coletivo Até o último homem: visões cariocas da administração armada da vida social, organizada por Felipe Brito e Pedro Rocha de Oliveira (São Paulo: Boitempo, coleção Estado de Sítio, 2013, p.148).

6. Ver o comentário de Pedro Rocha de Oliveira inspirado pela afirmação de um comandante de UPP segundo o qual os moradores precisam se acostumar com as "abordagens" nos territórios liberados. "E não perca no próximo programa: alguém morto sem motivo ao vivo", nalgum lugar da rede que o autor não me indicou ao enviar o artigo. O princípio, como sempre numa Era de Expectativas Decrescentes, é o do mal menor. A pressão policial é preferível à opressão do tráfico, ou à mais organizada, das milícias. Tese aliás abraçada, com a força proverbial do abraço dos afogados, pela esquerda legalista e punitiva, desde 2003 de passagem pelo governo. Ainda a respeito dessa alternativa sem alternativas, ver a entrevista de Frédi Vasconcellos e Mariana Gomes com Marcelo Freixo, "A escolha entre UPPs ou tráfico é uma armadilha" (Caros Amigos, maio 2013, pp.16-19). Em poucas palavras: à feição calamitosa do capitalismo contemporâneo - e cujo apodrecimento parece não anunciar mais nada - corresponde uma espécie de visão panglossiana às avessas, segundo a qual não viveríamos no melhor dos mundos possíveis mais num outro mundo, não menos admirável, regido pelo princípio do menor de todos os males possíveis. A conclusão é de Eyal Weiszman, refletindo sobre uma outra ocupação - a rigor, a mãe de todas a ocupações que hoje povoam o mundo -, a dos territórios da Palestina e o governo das suas populações segundo um dispositivo peculiar baseado no cálculo dos mínimos vitais compatíveis com o exercício contínuo, porém calibrado, da violência de qualquer forma inevitável e perene. The Least of All Possible Evils: Humanitarian Violence From Arendt to 
espalhar morro acima que uma gente indócil também não está se "acostumando", muito menos se conformando, com o novo padrão de abordagem nas ruas?

Basta uma amostra, o relato de uma jovem advogada presente no momento do conflito em que os manifestantes partiram para cima de um coronel da PM de São Paulo na noite de 24 de outubro de 2013. "Eu estava pouco antes desse momento, realmente deplorável, tentando falar com o Coronel, arrogante. Ele e outro soldado estavam pegando e anotando o RG de todos os manifestantes que passavam e de quem chegava perto só para ver o que estava acontecendo ou para quem perguntava por que tinham detido uma menina que não estava fazendo nada: qualquer manifestante era 'fichado' por eles. Apresentei-me como advogada e perguntei o motivo e finalidade desse fichamento. O coronel foi debochado e recusou-se a responder. Insisti e logo em seguida ele largou os RGs e partiu para cima de um garoto vestido de black bloc segurando um mastro tipo pau de bandeira. Avançou para cima do garoto e começou a bater, mas acho que não contava que todos que estavam em volta se revoltassem e partissem para cima dele para ele largar o garoto. Depois disso não vi mais, porque estourou a confusão e saí de perto [...]" O militante que me passou essa ilustração da

Gaza (Londres, Verso, 2011). Teremos tempo para verificar se as novas abordagens pacificadoras são uma variante desse grande dispositivo "moderador" da violência distribuída segundo algoritmos de escolhas entre danos que de qualquer modo serão infligidos. Assim, na faixa de Gaza sitiada rotineiramente, no exemplo de Weiszman, o garrote israelense é calibrado segundo padrões de "mínimos humanitários", dosando energia elétrica, calorias e outras necessidades vitais, de modo a governar as pessoas confinando-as ao limite administrável da mera existência física. Não quero forçar nenhuma analogia chapada, apenas sugerir como promete ser amplo o espectro das abordagens que vem por aí. O espectro pode perfeitamente evoluir de espasmos paroxísticos como um espancamento de rua ou uma reintegração de posse selvagem, à calibragem administrativa de níveis de pobreza. nova "abordagem" acrescentou um comentário cujo resumo poderia ser o seguinte: se me pedissem para condensar em duas palavras a real novidade de Junho, diria o seguinte: agora há reação. Fiquemos com a última, ou melhor, com a primeira do ano de 2014, pelo menos com a primeira a ser registrada e ter ampla repercussão na mídia comercial, para não falar das redes, que aliás não são menos comerciais, embora atendam pelo nome de sociais. Como esperado, os protestos de rua voltaram no dia 25 de janeiro. O primeiro manifestante baleado pela polícia caiu em São Paulo, ferido a tiros no tórax e na virilha. No momento em que escrevo está em coma induzido na Santa Casa, para onde foi conduzido pelos próprios policiais, contrariando normas recentes de atenuação das estatísticas, pois é a caminho que se costuma completar o serviço. Para efeito de raciocínio, vamos adotar a versão da polícia. Ao ser abordado e ter a mochila revistada, Fabrício Chaves fugiu correndo com três policiais no seu encalço; sentindo que seria alcançado, voltou-se com um estilete na mão e partiu para cima de um dos policiais, que então atirou em legitima defesa, com a atenuante de que já estava no chão, empurrado pelo seu agressor. As execuções na periferia são expeditivas. Quando o alvo se desloca em velocidade, ignoro quais são os protocolos. Na região central de São Paulo, três policiais com arma de fogo interpelaram um jovem que, depois de correr em vão, os encarou com uma arma branca. Admitamos que por uma vez a polícia não tenha forjado um BO. No início do segundo capítulo de Junho, ainda não temos resposta para a pergunta, quem sabe a única capaz de abrir caminho sob a tonelada de senso comum que se abateu sobre o país: por que Fabrício parou de correr? Podemos não saber ainda por que parou, mas podemos presumir sem muito erro o que sen- 
tiu enquanto corria pela rua: "uma impressão de pavor [...] a postura da cabeça, tentando manter-se erguida é de alguém que se afoga, o rosto tenso assemelha-se à careta de dor. Ele tem que olhar para frente, quase não consegue olhara para trás sem tropeçar, como se seu perseguidor cuja visão deixa-o gelado de horror - já respirasse em sua nuca. Outrora corria-se de perigos demasiado terríveis para que se lhes fizesse face e, sem saber, disso ainda dá testemunha quem corre atrás do ônibus que se afasta velozmente. O regulamento de trânsito não precisa mais levar em conta os animais selvagens, mas ele não conseguiu apaziguar a ação de correr". Também sabemos de qual animal selvagem Fabrício estava correndo: "ninguém deixa de sentir um frio na barriga quando é parado pela polícia. Até porque, se você está limpo, ninguém garante que a polícia esteja. Todo mundo sabe que com a polícia tudo é possível. E todo mundo sabe que para o Estado, que está por traz da polícia [...] somos todos não-pessoas [...] E se eu for pobre, aí a situação é realmente grave [...] Na relação com o Estado estamos todos mortos. Não é por acaso que o fisco é o leão [...] é justamente o encontro com o leão na mata”. O primeiro trecho encontra-se nas Minima Moralia, de Adorno; o segundo, numa palestra do antropólogo Eduardo Viveiros de Castro, "A morte como quase acontecimento", e ambos se encontram no livro da socióloga Silvia Viana sobre os reality shows, Rituais de sofrimento ${ }^{7}$, onde por meu turno os encontrei, o primeiro havia lido e esquecido, o segundo, não conhecia. Os dois fragmentos falam por si, mas o fato de serem citados e comentados num estudo sobre a alienação contemporânea do trabalho - aqueles monstrengos televisivos não são mera patologia

7. São Paulo, Boitempo, 2013, pp.100-101 e pp.159-60, respectivamente. ilustrada, mas a exibição em tempo real de pessoas trabalhando de verdade para produzir a eliminação de outras pessoas que também estão trabalhando de verdade para o mesmo fim - lança uma luz nova sobre a fuga de Fabrício e o bafo arcaico da violência congelando-lhe a nuca enquanto corre, depois do mau encontro na selva, a quase morte vivida em plena mata de Higienópolis, a única experiência diante da qual, segundo o antropólogo, nos sentimos completamente abandonados, o que torna ainda mais misteriosa a fonte de energia que permitiu a Fabrício parar e olhar para traz sem se deixar congelar pela visão de seus perseguidores. Graças à imaginação sociológica de Silvia Viana podemos agora reconhecer o terror que mal se esconde nas imagens hipervalorizadas hoje em dia, nas "cenas de gente apressada de um lado para o outro, para cima e para baixo, se trombando, tropeçando, atropelando na rua, na cozinha, no ateliê, na passarela”. Parece simulação mas é trabalho real, intensificado pela aceleração rumo à degola que cedo ou tarde virá, que por sua vez não deixa de ser uma simulação, pois assim ninguém consegue trabalhar de fato. Trata-se de uma correria só, sem antes nem depois. Por essa pista, o estudante de escola técnica e estoquista (daí o estilete) Fabrício Chaves já corria há algum tempo, ao correr também da polícia. Mudou a faixa, mas a equivalência entre "correr atrás" e "aguentar a pressão" continua a mesma. Na formulação de Silvia Viana: "A premência de alcançar o que está à frente é sempre também a fuga febril de uma ameaça que se aproxima por trás". Como seu ancestral, Fabrício correu para sobreviver (até Hobbes lhe faculta esse direito), mas não só. Não correu como o prisioneiro (que praticamente já era) a quem a polícia teria dado a ordem de correr para ter um pretexto para assassiná-lo (como estava a ponto de acontecer). Até 
o momento em que deu meia volta e encarou a quase morte do mau encontro, descartando a correria como único horizonte concebível. Primeiro na rua, quem sabe logo mais no trabalho. Mas não sabemos, nem mesmo por que parou e se voltou.

Tudo somado, sobram analogias sumárias na origem dessa outra visão carioca, tão fora de foco que não sabemos mais onde termina a percepção alucinada e principia uma outra ameaça, esta sim bem mais tangível. Ligue os pontos e verá para onde caminham esses manifestantes que não fogem mais da polícia, inverta o raciocínio e verá que, baixada a poeira da tarifa, o tal rastro de destruição que deixam atrás de si revela um outro endereço. O Secretário de Segurança Pública nunca escondeu o que de resto mostram muito bem os mapas de localização das UPPs, a saber, que os territórios pacificados formam um cinturão de segurança para os megaeventos a caminho. Ora, quem ousou sitiar arenas da Copa está de fato mandando um salve geral aos candidatos naturais a quebrar aquela grade de proteção. Pensando bem, não é para surpreender tanto assim: o que exigiam, logo nos primeiros dias que a chapa esquentou e o trânsito parou, editorialistas, colunistas, mais o pessoal da moral-e-cívica nos talk shows? Justamente que se reconquistasse a Av. Paulista, a Cinelândia etc. Enfim, todos os espaços tomados e conspurcados por manifestantes abusados. Na semana seguinte, a onda verde-e-amarela das bandeiras atestava que a missão fora cumprida, os medos urbanos reais e imaginários haviam decifrado em silencio o ar de família que circula em comandos do gênero: faxinemos a Cinelândia com a mesma energia cívico-militar com que libertamos o Alemão. A fixa caiu antes de junho chegar ao fim, mas só foi cantada, como estamos vendo, depois de um par de me- ses de embates pelo domínio da rua. Na visão, é claro, de quem opera segundo a lógica de ocupação de territórios, como é o caso tanto das facções que controlam o varejo da droga quanto dos agentes armados da pacificação desses mesmos espaços de segregação e estigma. ${ }^{\mathbf{8}}$

Desde Junho, essa territorialização violenta se estendeu das ruas ao perímetro inviolável dos megaeventos. Contiguidade contagiosa, que por sua vez inspirou a política envenenada do argumento retardatário cujos pontos procuramos ligar. Depois de igualmente reparar que a ideia absurda de "retomada do espaço público" invadido por manifestantes predadores não difere muito da dinâmica de instauração das UPPs, a advogada voluntária e defensora dos direitos humanos, Gabriela Azevedo, tocou no ponto nevrálgico dessa visão de território: nela sempre se recorta um canto "no qual se pode suspender o ordenamento, invisibilizar, incluir, excluir e matar (lato sensu) de várias formas ao sabor da vontade política"9. Espaços de exceção, em suma, onde a lei é como que

8. A "pacificação" - como lembrado, por exemplo, por Michel Misse-reiterou a lógica perversa da territorialização, daí as aspas de rigor, e mais, com o tempo essa mesma lógica de conquista e de controle estará pavimentando o caminho dos dois principais mercados ilegais: o que oferece drogas a varejo e o que oferece mercadorias políticas, "proteção", no caso. Michel Misse, "Os rearranjos de poder no Rio de Janeiro", Le Monde Diplomatique Brasil, jul. 2011 pp.6-7. Desnecessário lembrar que neste mesmo julho de 2011, dando um balanço nas consequências e pressupostos históricos da maior intervenção militar em favelas na cidade do Rio de Janeiro, a ocupação do Complexo do Alemão em novembro de 2010, Vera Malaguti Batista principiou sua peculiar "desconstrução" das UPPs e o "macabro consenso" que se formou à direita e à esquerda (vá lá), em torno delas, justamente por uma problematização do conceito de território e sua sinistra genealogia brasileira enquanto alvo perene de ocupações militarizadas e massacres. "O alemão é muito mais complexo", texto apresentado no $17^{\circ}$ seminário de ciências criminais, São Paulo, 23 de julho de 2011, incluído no volume coletivo, Paz armada, coleção Criminologia de Cordel (Rio de Janeiro, Revan, 2012).

9. Comunicação no colóquio Horizontes 2013/Cidades Rebeldes, Curitiba, 12 de nov. de 2013, Faculdade de Direito da UFPR. Cito de acordo com o texto que a autora gentilmente me pôs à disposição. 
desativada, zonas cinzentas nas quais os protocolos da "resistência seguida de morte" são a senha de uma autorização para matar, zonas cujo epicentro pode ser tanto um ponto de droga quanto os circuitos informais de comércio popular. ${ }^{10}$ Pois o que o relato de Gabriel a Azevedo mostrou é que esses espaços de exceção - antes restritos aos circuitos de relegação da pobreza estigmatizada -, vazaram para a rua política ante a surpresa intolerável da desobediência recalcitrante e incivil, pior ainda neste mesmo plano do inusitado, a contaminação alcançou a greve dos professores da rede municipal carioca, entornando de vez o caldo, juntando e misturando "baderna" e uma categoria histórica de trabalhadores organizados. ${ }^{11}$ Assim, ao gás pimenta e à bala de borracha adicionou-se o Pacote de Ilegalidade, que desde então não para de crescer e multiplicar-se. ${ }^{12}$

10. Para um apanhado geral dessas "zonas de arbítrio" em que operam as práticas de extorsão dos mercados de proteção, Vera da Silva Teles, A cidade nas fronteiras do legal e do ilegal (Belo Horizonte, Argumentum, 2012), em particular o capítulo 5 sobre a dimensão territorializada da gestão diferencial dos mais diversos ilegalismos onde só há, segundo o dito popular, "ou acordo, ou a morte, não a prisão".

11. A respeito dessa fusão inaugural de métodos de luta correspondentes a tempos históricos diferentes, ver as observações de Giuseppe Cocco em entrevista a Patrícia Benvenutti (Brasil de Fato de 17-23 de out., p.4): "quando os professores se mobilizaram, o fizeram de maneira tradicional, com passeatas, organizadas a partir do carro de som do sindicato, com uma dinâmica que não era aquela do movimento de junho mas de repente a mobilização não encontrou nenhum espaço de negociação junto aos poderes públicos, nenhuma mediação por parte da Prefeitura e foi se radicalizando. A partir da ocupação da Câmara Municipal, passou a ser algo diferente, dialogando diretamente com o levante da multidão. É uma luta da categoria que acabou sendo uma luta da cidade. É uma movimentação da categoria, mas que se faz na brecha aberta pelo movimento de junho que, em particular no Rio de Janeiro, teve uma continuidade praticamente diária."

12. Pacote da Ilegalidade é o apelido carioca da parte mais acintosamente visível e alardeada do estado de exceção ainda, por assim dizer, juridicamente clássico. Na enumeração de Gabriela Azevedo, "abarca desde pronunciamentos do executivo, embasando a suspensão do ordenamento e a identificação
Resumindo, ficamos assim: quem não se manifestou dentro da lei e da ordem, e continuou quebrando vidraças depois que a onda cívica voltou para casa, estava objetivamente afim de pôr fogo no circo das UPPs, sabotar os dividendos da paz, detonando em primeiro lugar a redenção urbana, econômica e social que viria no rastro dos megaeventos. E pouco importa se a campanha de rua para barrar o aumento das tarifas no transporte público, ou, na vaga sucessiva, o fogo de barragem dirigido contra as bolhas de exceção da FIFA, jamais cogitaram visar e minar a paz dos pacificadores de favelas: a linha imaginária e paranoica ligando tais pontos vinha confirmar um mau sonho carioca, uma desconfiança pesada e jamais formulada de que as UPPs

do inimigo, passando pelo posicionamento pouco (ou muito?) ortodoxo de certos magistrados (de sentenças altamente punitivas a originais restrições impostas quando da decisão da liberdade), chegando à instauração, por meio de decreto do executivo estadual no 44302 (qualquer coincidência com uma medida de exceção...), da CEIV (Comissão Especial de Investigação de Atos de Vandalismo em Manifestações Políticas), que apesar da vida curta deixou frutos - diversos inquéritos policiais instaurados até correm ainda sob sigilo". E por aí vamos no rol dos monstrengos como na Lei dita das máscaras (Lei Estadual no 6528 de 11 de setembro de 2013), Lei de Associações Criminosas (Lei no 12850), de 2 de agosto de 2013, reativação da Lei de Segurança Nacional de 1983 no 7170 etc. Para um outro complemento deste etc., como a iniciativa anunciada em 31 de outubro pelo ministro da Justiça, de criação de tribunais itinerantes durante as manifestações além de outras medidas relativas à ativação de legislação de exceção, ver André Sá Caldas, Eduardo Backer e Thiago Melo, "Surge um novo inimigo interno", Le Monde Diplomatique Brasil, Dez. 2013, p.38. Ainda para um elenco comentado de violações ocorridas no Rio durante e depois de junho ver Taiguara Souza, professor de Direito Penal e membro da Comissão de Direitos Humanos da ALERJ, "Essa resposta altamente truculenta e violadora dos direitos fundamentais busca ocultar a legitimidade da reivindicação", entrevista a Viviane Tavares para o Brasil de Fato de 31 de outubro a 6 de nov. de 2013, pp.10-13. Vale ressaltar na entrevista um tópico, no capítulo das grandes continuidades em nossa transição infindável e o regime hibrido que a caracteriza desde a conclusão oficial da ditadura: a visão segundo a qual "aquele cidadão que está nos protestos populares é considerado um inimigo que deve ser combatido, a ação da polícia remonta à ideia do toque de recolher, muito característico da época da ditadura que é retirar o manifestante da rua". 
talvez não fossem bem a ansiada "formula mágica da paz" enaltecida pelos seus idealizadores, nem tampouco se reduzissem ao papel de meros facilitadores de negócios, como querem seus detratores, sintomas enfim de uma neurose objetiva e como tal premonitória, saídas de emergência porém preventivas de uma urgência maior e não sabida, e não obstante a caminho. Dia 18 de dezembro de 2013, o Programa de Pacificação das Favelas, deflagrado pelas UPPs, fez aniversário. Sua mais remota e funda razão de ser finalmente revelou-se em Junho. Oito anos de espera depois, os bárbaros chegaram. ${ }^{13}$ A fantasia punitiva dos pacificadores só parecia tresloucada por ser exata. É que os tempos estavam trocados, bem como a ordem de chegada dos personagens em cena. Sem falar na denominação inusual que logo se verá, há dois anos adormecida no vocabulário político da cidade.

13. Ao contrário da espera frustrada pelos bárbaros redentores no poema de Cavafis, "A espera dos bárbaros", desta vez eles de fato chegaram: não seriam por certo a solução, mas a rima que afinal veio a confirmar os muitos anos de expectativa de um perigo eminente beirando a catástrofe, e sem a qual não se cristalizaria o "Consenso macabro" que culminou nas UPPs. Não evoquei à toa o poema de Cavafis, mas para relembrar que ele fornece uma das epígrafes à Cidade partida, de Zuenir Ventura (Op. cit. p.53). A crise, cujo sinal de alarme fora soado vinte anos atrás, porem como sinal de largada para o city marketing da futura Cidade Olímpica, finalmente encontrara o inimigo dos seus sonhos.
2.

Quem a despertou de uma latência de duas décadas, a julgar pela data de declaração da guerra ao contrário, com a qual sonhavam os pacificadores de 1993 foi, primeiro, o golpe de vista bem treinado de um diplomata norte-americano associado ao posto brasileiro de seu país. Segundo, graças a um dos tantos vazamentos do WikiLeaks, o não menos certeiro censo das desproporções reveladoras do pesquisador e militante Eduardo Tomazine Teixeira num artigo publicado no jornal eletrônico Passa Palavra em 13 de janeiro de 2011, "A doutrina da pacificação"14. Pois bem. Segundo Mr. Hearne, "o Programa de Pacificação de Favelas compartilha algumas das características da doutrina e da estratégia de contrainsurgência dos EUA no Afeganistão e no Iraque. O sucesso do programa dependerá, em última instância [...] da percepção dos moradores da favela quanto à legitimidade do Estado [...] assim como na contrainsurgência, a população do Rio de Janeiro é o verdadeiro centro de gravidade [...] um dos principais desafios desse projeto é convencer a população favelada que os benefícios em se submeter à autoridade Estatal (segurança, propriedade legitima da terra, acesso à educação) superam os custos (taxas, contas, obediência civil)”. À primeira vista o disparate não podia ser maior. Para atenuá-lo, Tomazine foi se informar, verificando que a doutrina e a prática da contrainsurgência não são os mesmos

14. Publicado no Globo online, o telegrama, como se dizia antigamente, também chamou atenção de Vera Malaguti Batista, que o incorporou a seu argumento geral acerca do laboratório carioca de gestão policial da vida (Op. cit. p.77). Eduardo Tomazine ainda publicou uma segunda versão daquele artigo pioneiro, "A pacificação de favelas no Rio de Janeiro: a contrainsurgência preventiva?”, no Alterinfos América Latina, 14 de mar. de 2011. 
do tempo da Guerra Fria - "deslocamentos forçados de populações, recrutamento obrigatório da população local para as forças de segurança, rígidos toques de recolher, pressão letal sobre os civis para se colocarem ao lado do governo", nas palavras de uma alta patente americana, ressaltando o anacronismo daquelas táticas da guerra irregular empregadas nas selvas do sudeste asiático e da América Central. Não será demais observar de passagem que as remoções forçadas estão aí de volta entre nós faz algum tempo, e tempo desenvolvimentista, para ser preciso. Mas não avancemos o sinal. Uma importante voz dissidente na comunidade intelectual norte-americana de segurança, o historiador militar Andrew Bacevich, recomenda inverter o raciocínio se quisermos atinar com a reviravolta que veio bater no Rio. Contrainsurgência foi o nome da moda ${ }^{15}$ dos tempos em que se combatia no solo a guerra revolucionária de novo tipo que o exército francês descobriu na derrota na Indochina e depois reverteu a seu favor na infame Batalha de Alger, travada na base da tortura e do atentado terrorista, como há de se recordar - e sua ressurreição contemporânea (a revolução armada nos trópicos foi enterrada faz tempo) demanda outra explicação. A saber: por volta de 2006, Bagdá parecia a Beirute da guerra civil em 1983, só que muito pior, a truculência high tech do Choque e Pavor simplesmente não funcionara - algo como a nossa estratégia doméstica "pé na porta” à enésima potência tecnológica -, de sorte que o Estado Maior da vez tirou da manga um novo Manual de Campo, o desde então venerado FM 3-24, ao qual se atri-

15. E depois o nome do horror praticado pelos Contra na Nicarágua e El Salvador na última década da Guerra Fria. Veja-se o terceiro capítulo, "Going Primitive", do livro de Greg Grandin sobre o laboratório centro-americano da carnificina praticada na fase de descida aos infernos da guerra do Iraque, Empire's Workshop (Nova York: Metropolitan Books, 2006). bui a inflexão favorável no curso das guerras gêmeas no Iraque e no Afeganistão ${ }^{\mathbf{1 6}}$, dando continuidade por outros meios à essência da estratégia Bush, a da guerra sem fim, inclusive no que concerne objetivos palpáveis, que não o da perpetuação da constelação de organismos e interesses que compõem o Estado de Segurança Nacional ${ }^{17}$.

$\mathrm{Na}$ raiz da mudança terminológica prestigiosa, uma senhora mistificação, no entanto desbravadora de um inestimável roteiro ideológico. Pensando em termos de história militar, contrainsurgência hoje, afirma Bacevich, é uma moeda falsa, uma fraude destinada a perpetuar o estado de guerra no mundo, pois a "segurança da população”, por definição, é uma porta que nunca se fecha. (Ou a Segurança Humana, o nome do jogo hoje) ${ }^{18}$. Pois diante

16. Venerado a ponto de merecer uma publicação pela editora da Universidade de Chicago (2007), acompanhada por uma introdução entusiasta da então diretora do Centro Carter para Direitos Humanos de Harvard. Sigo adiante o comentário de Eyal Weiszman (cit. pp.17-19 e p.119, para as notas). Saudando a colaboração sem precedentes entre um centro de direitos humanos e as forças armadas, a referida diretora (Sarah Sewall, para ser preciso) lembrava que, numa ação militar, baixa civis em excesso além de um possível erro moral, são antes de tudo uma tática self-defeating, e que por isso o Manual acertava em cheio, ao permitir que o direito humanitário, e os princípios dos direitos humanos se convertessem em ferramentas indispensáveis nas mãos das forças de ocupação empenhadas em "ganhar" as populações civis e se convertessem enfim naquilo no que os Direitos Humanos se tornaram, uma técnica de governo, uma vez encerrado o período épico inaugural da luta contra os poderes exterministas e desaparecedores das ditaduras plantadas na América Latina justamente, suprema ironia, na esteira da contrainssurgência histórica.

17. Andrew Bacevich Washington Rules: America's Path to Permanent War (Nova York: Metropolitan Books, 2010, cap.5, "Counterfeit COIN"), e ainda do mesmo autor, "Social Work With Guns", London Review of Books, 17 de dez. de 2009.

18. Mary Kaldor, Human Security: Reflections on Globalization and Intervention (Cambridge: Polity Press, 2007, cap.7) Para um comentário que nos concerne, se é verdade que hoje a Guerra não é mais guerra, mas antes de tudo Intervenção, e intervenção securitária, ver os dois livros de Frédéric Gros, États de violence: essai sur la fin de la guerre (Paris: Gallimard, 2006), Le principe securité (Paris: Gallimard, 2012). 
dos escombros da estratégia Choque e Pavor, como se disse, a inteligência militar chegou à conclusão de que a natureza da guerra contemporânea mudara inteiramente, muito menos uma decorrência do teorema - como se exprimiu um membro do Estado Maior quando as primeiras bombas começaram a cair sobre Bagdá - "velocidade é poder", e muito mais, se não tudo, quando se deseja "mudar o modo de vida deles", quase uma saída para a questão social, forçando um pouco a nota do grotesco na presente situação. Na frase mais precisa de Bacevich, um trabalho social armado. Numa palavra, não se trata mais de "vencer batalhas mas de pacificar populações" (grifo meu) ${ }^{\mathbf{1 9}}$, por meio de "boa governança", "desenvolvimento econômico", "segurança pública" - enfim, todo o pacote em que se entrelaçam hoje Welfare e Warfare. O soldado protagonista de uma intervenção social armada, além de exercer o papel de trabalhador social, precisa atuar igualmente como planejador urbano, antropólogo e psicólogo ${ }^{20}$ e com isso tudo, inevitavelmente um "policial", como o redefinira a tempos Mary Kaldor, na primeira obra de referência acerca das novas guerras pós-clausewitzianas ${ }^{21}$. O nome

19. Andrew Bacevich, Washington Rules (cit. p.208).

20. Eyal Weiszman (cit. p.18).

21. Mary Kaldor, New and Old Wars: Organized Violence in a Global Era (Stanford: Stanford University Press, 2009, pp.125-130). Sobre este tópico contemporâneo crucial - a policialização das novas guerras e a correspondente militarização das forças policiais - procurei reunir, num argumento só, algumas referências num estudo de 2002, "Notícias de uma guerra cosmopolita”, recolhido depois no volume de ensaios Extinção (São Paulo, Boitempo, 2007). No campo da crítica anti-sistêmica radical, surgiram pouco depois pelo menos duas contribuições, Robert Kurz Weltordnungskrieg: das Ende der Souveränitat und die Wandlungen des Imperialismus im Zeitalter der Globalizierung, em especial os capítulos sobre a Polícia do Mundo e o Estado de Exceção Global (Badhonnef: Horlemann, 2003); Michael Hardt e Toni Negri, Multitude: guerre et démocratie à l'age de l'Empire (Paris: La découverte, 2004, Parte 1). Para uma avaliação abrangente e atual do quanto esta fusão en- do pacote, como sugerido, é governo, ou um conjunto de técnicas cujo objetivo é a segurança (em todo seu espectro) e o alvo, uma população assentada (mal) num território, cuja matriz de percepção por analogia é um ambiente urbano saturado de conflitos. Mas com isto, processou-se uma tremenda e não prevista reviravolta, e é onde estamos: do despropósito histórico na ressureição do ideário operacional da contrainsurgência, chegamos a um encaixe não menos histórico, a visão do "trabalho social" como uma operação de contrainsurgência. E esta última, quem diria, repaginada como uma política pública, no caso política de pacificação ${ }^{22}$. Não surpreenderá

tre militarização e policialização avançou, bem como a convergência paralela entre guerras de baixa intensidade e policiamento de alta intensidade, ambos os processos transcorrendo preferencialmente num teatro cada vez mais urbanizado, a ponto de caracterizar o que está sendo chamado de "urbanismo militar", ver Stephen Graham, Cities Under Siege (Londres: Verso, 2010), e, organizado pelo mesmo autor, Cities, War and Terrorism (Oxford: Blackwell, 2004). Estudando o laboratório carioca de militarização policial da vida, como assinalado, os autores de Até o último homem chegam a conclusões muito semelhantes. Está portanto na hora de dar um balanço em mais este capitulo da concomitante periferização do núcleo orgânico do sistema e "emergência", não menos orgânica, da periferia, o conjunto confluindo num mundo único de tal modo "pacificado" que "até os cães serão vacinados", como se podia ler no Jornal de Brasil de 2 de jun. de 1988, celebrando mais uma invasão definitiva da Rocinha pela Polícia Militar, enormidade incomensurável devidamente glosada pelos autores do livro mencionado a partir da página 264.

22. Que neste caso específico, Eduardo Tomazine, batizou, como se lê no título de seu artigo de "doutrina da pacificação", uma particular engenharia carioca de controle social, combinando o "choque" característico do capitalismo de desastre segundo Naomi Klein (quando o medo e o desespero provocados por abalos emergenciais se transformam em oportunidade de negócio), e a acumulação por espoliação, como David Harvey denominou a permanência da acumulação primitiva histórica na engrenagem de reprodução e expansão do capitalismo contemporâneo. A “doutrina” dessa outra fórmula mágica da paz, para voltar a falar como os Racionais, é obviamente uma paródia da fraseologia americana da grand strategy, e se explica porque, na engenhosa construção de Tomazine, para soldar choque e espoliação na gestão de territórios na orla da nova onda de exploração econômica no Rio de Janeiro, é preciso um dispositivo especial de governo, as UPPs, frente e verso, coerção e serviço social, no qual o diplomata americano prontamente reconheceu um equivalente da estratégia atualizada da contrainsurgência, a qual associada às novas 
então que o círculo dessa reviravolta espantosa se feche com a conclusão sinistra: tudo portanto deve ser passar como se o público-alvo, como o nome indica e assinala, de todo esse dispositivo de governo fosse potencialmente insurgente. Mas pensando bem, quem é afinal o alvo?

O problema é que os suspeitos de sempre seriam os menos indicados para preencher a vaga de insurgente. Por mais que mídia e governantes assoprem a brasa dormida das facções, a ameaça de uma provável contraofensiva do varejo enxotado aqui e ali, é só isso, uma ameaça, destinada sobretudo a despertar o ânimo bélico dos pacificadores. Desnecessário insistir, relembra Tomazine, examinando os candidatos, o pessoal do "movimento" não é nem de longe "insurgente", mas de fato os elos mais fracos - daí a violência - do circuito internacional do comércio de drogas e armamentos, sua anomia é conformista, e embora desafiem o monopólio estatal do uso da violência dita legitima, como gostam de recordar os sociólogos ofuscados pela evidência de que o Estado está voltando a ser a relíquia arcaica que sempre foi, um bando armado que vende proteção, nunca cogitaram enfrenta-lo para valer, embora o façam para negociar em melhores condições, como se viu na sublevação do PCC em maio de 2006 em São Paulo, muito menos têm qualquer pretensão que poderia se chamar de política - salvo a ironia macabra de que o assim chamado Estado de Direito faça valer suas prerrogativas pelo menos na legislação em princípio garantista da Execução

tecnologias onusianas de peacekeeping - bem testadas pelos agentes nacionais no Haiti, por exemplo - veio paradoxalmente desembarcar num ambiente metropolitano cujos conflitos só por metáfora poderiam ser verdadeiramente chamados de guerra. Contrainsurgência então meramente preventiva, como pergunta na segunda versão do artigo? Seja como for, a mera prevenção-como estamos sugerindo desde o início - abriu um conjunto vazio de expectativas que praticamente suscitou o seu cumprimento num segundo tempo social.
Penal. Nisto são até litigantes de boa-fé, jamais insurgentes. Não é, portanto, o comércio varejista de substâncias ilícitas, tocadas pelos donos do morro, que se "insurge" contra "a valorização capitalista das favelas por meio da ocupação policial permanente dos territórios”. Resta a "geração perdida" da população favelada - na acepção que lhe deu um oficial do BOPE, em conversa reportada pelo nosso Mr.: aqueles moradores que viveram décadas sob o controle do tráfico e a informalidade dos serviços via de regra providos por fontes piratas. Pois é essa geração e sua circunstância que Tomazine considera o alvo das grandes manobras cariocas de contrainsurgência. É que pacificá-los significa quebrar sua resistência - e potencial insurgência - a assumir suas novas responsabilidades perante a suposta normalização capitalista de todas as prestações econômicas e sociais. Tampouco havia insurgentes em pé de guerra nas ruas mais obscuras e violentas de Porto Príncipe, apenas cidadãos pobres e desamparados ${ }^{23}$. Em

23. Mas quando sobreveio a devastação cataclísmica do terremoto, a MINUSTAH (e o correspondente sorvedouro ongueiro de recursos internacionais) cuidou apenas de salvar a própria pele aquartelando-se. No relato notável do antropólogo Omar Ribeiro Thomaz, a virtual "insurgência" do povo pobre e abandonado à própria sorte de Porto Príncipe apresentou-se então na forma de uma surpreendente (para os que temiam, entrincheirados em suas posições, o assalto de uma horda bárbara) capacidade de auto-organização e cuidado dos outros em proporções jamais vistas, sobretudo porque da ignorância em que vivemos do Haiti só se esperam estereótipos. Como a aproximação UPP/ MINUSTAH trivializou-se, à esquerda e à direita, não seria demais reconsiderar uma outra hipótese preliminar, além da sugerida linhas acima - todo esse enorme e próspero aparato de ajuda internacional não tem outra finalidade senão a de carrear ainda mais recursos para sua própria auto reprodução - a saber, que o polêmico impacto das tropas brasileiras no Haiti "não encontra eco para além de nossas próprias fronteiras”, numa palavra, “a presença especifica brasileira naquele pais é algo para consumo interno dos brasileiros", Omar Ribeiro Thomaz, "O terremoto no Haiti, o mundo dos brancos e o loupgawou", Novos Estudos, n. 86, mar., 2010, pp.23-24. É por essas e por outras que os observadores mais heterodoxos do laboratório carioca de administração social armada costumam privilegiar o vínculo direto dos vasos sociais comunicantes entre Porto Príncipe e o Rio de Janeiro, destacando, por exemplo, que não foi obra do acaso a coincidência de que o comando das incursões militares no 
suma, considerá-la "potencialmente insurgente", conclui Tomazine, é encarar seriamente a contrapartida de "não haver no Brasil um verdadeiro inimigo interno", mas ao mesmo tempo uma população oprimida e recalcitrante, que desconfia e reluta, quando não se insubordina, diante do preço de mercado a pagar pelo despertar de sua subjetividade empreendedora. Quem dera ${ }^{24}$.

E se o paradoxo da contrainsurgência preventiva, da contrainsurgência sem insurgência, fosse redescrito me-

Complexo do Alemão e Vila Cruzeiro tenha sido entregue a um oficial superior veterano da MINUSTAH. Cf. Felipe Brito “Será guerra?”, capitulo do mencionado em Até o último homem, p.221.

24. Depois de se reportar ao mesmo despacho diplomático norte-americano acerca do Programa de Pacificação de Favelas e o renascimento (historicamente fraudulento) da doutrina da contrainsurgência, Felipe Brito, na passagem citada na nota anterior, se detém igualmente nas alternativas consideradas por Tomazine. Também descarta de saída a hipótese de uma contraofensiva do tráfico, cujos padrões comerciais não comportam qualquer inquietação política, salvo as barganhas de praxe. Mas acompanha nosso autor, ao admitir que de fato não é fortuito o desconcertante parentesco entre a pacificação via UPPs e as iniciativas caracterizadas pelos novos Manuais de Campo das forças armadas americanas como de contrainsurgência. Curiosa equação retrospectiva, sem dúvida: o operador do varejo ilegal, cujo confronto armado com a autoridade estatal visava exclusivamente a viabilidade econômica do seu comércio, ao ser pacificado e "incluído" como um "empreendedor", passa a ser revisto como um personagem cujo papel nunca exerceu, um ex-insurgente. A imaginação alimentada pelo discurso das novas guerras fecha a conta. É claro, quem não sabe dos vínculos óbvios entre as ditas insurgências que fervilham pelo mundo e os círculos inferiores do narcotráfico, sem falar no despotismo dos reis do morro, cujo domínio sobre populações abusadas, escala a menos, também teria tudo a ver com os relatos de horrores perpetrados pelos novos senhores da guerra mundo afora. Sarcasmo a parte, e como a blindagem do senso comum parece cada vez mais inexpugnável nos dias que correm, embora em vão, relembro que tais "visões cariocas da administração armada da vida social", se têm algum ponto cego, certamente não é o desconhecimento ou minimização de que "a presença de grupos armados com domínio sobre o território [...] é um pesadelo permanente para o conjunto da população carioca”, o que não os impede de destacar antes de tudo o outro ponto cego, real e simétrico, que esse tormento social só se tornou "um problema que demanda ações de emergência" - passada a retórica belicista do confronto - quando a iniciativa de diminuição da letalidade dos conflitos apresentou-se como exigência de uma reestruturação urbana concebida como cinturão de segurança para uma nova onda de investimentos expropriadores (Op. cit.., por exemplo, pp. 144-5). nos como uma "inclusão extorquida" do que como um dispositivo de substituição de comando na fabricação social de um produto novo no mercado de políticas públicas, a favela pacificada? Empreendimento inviável sem o envolvimento “cidadão" da polícia, que obviamente só poderia mesmo ser militar, e uma invisibilização preliminar da violência do tráfico, acompanhada por uma subsequente demão de vizibilização máxima de ações sociais. Que hoje mudaram, tais ações sociais: não são mais as mesmas que se presumiam dever ser há trinta anos atrás, na década da reinvenção brasileira do "social", como lembrado. Um social por substituição, digamos assim. Como a pacificação contrainsurgente (a expressão é prolixa, mas nos permite abandonar as aspas) é um dispositivo destinado a incitar os moradores a se tornarem gerentes de algum empreendimento, compreende-se que nunca se tenha cogitado, salvo para efeito de propaganda, a extinção dos antigos gerentes do comércio ilegal, e sim seu desarmamento e substituição por novos gerentes do território ${ }^{25}$. Substituição em dois

25. Lívia de Tommasi e Dafne Velazco, "A produção de um novo regime discursivo sobre as favelas cariocas e as muitas faces do empreendedorismo de base comunitária", texto apresentado na $35^{\mathrm{a}}$ Reunião da ANPOCS, Caxambu, 2011. Ver ainda, Lívia de Tommasi, "Culturas de periferia: entre o mercado, os dispositivos de gestão e o agir político", Política e Sociedade, Vol. 2, n. 23, 2013; e também, sempre acerca da emergência da "subjetividade empreendedora” dos pobres promovida pela difusão de códigos e práticas internalizados por indivíduos "pacificados", Dafne Velazco, "Intervenções sociais ligados à juventude e à produção da 'cidade integrada' no Rio de Janeiro", manuscrito ainda inédito quando gentilmente cedido pela autora, como aliás os dois anteriormente citados. Visto pelo ângulo crítico destes estudos, o empreendedorismo dos pobres "libertados" pela pacificação aparece menos como o engodo que realmente é, nele incluído uma polarização social de segundo grau, apartando o pobre-incluído de seu semelhante que afundou um pouco mais, do que como uma bem-sucedida tecnologia de governo de condutas - para falar como Foucault, que é um pouco a língua política das autoras - , e como tal perseguida por ser mobilizadora, algo como um arremedo de engajamento, que parece contagiar com um sopro redentor qualquer transação econômica ou social celebrada (e é este o nome, pois tudo termina em "evento") no âmbito da comunidade envolvida, de sorte que a pacificação como dispositivo de conduta 
tempos, segundo o protocolo da contrainsurgência. E uma contrainsurgência en creux, como se está vendo, operando num vazio insurrecional imaginário nem por isso menos coercitiva e disciplinadora. Com o necessário low profile adotado pelos donos do morro, o foco se volta preferencialmente para a arregimentação dos trabalhadores de chão de fábrica do tráfico, cujo plano de carreira não previa o acesso ao fuzil e seu poder de sujeição, vidas arriscadas na tarefa de matar um leão por dia, como se diz hoje no jargão da autenticidade batalhadora, que o olho clínico dos planejadores da contenção social - treinado de resto durante mais uma década no garimpo dos recursos humanos liberados em abundância pela inelutável ossificação geral dos movimentos sociais clássicos - já havia identificado muito antes do desembarque graças aos postos avançados das ONGs, tanto faz se do bem ou do mal, essas tecnologias de controle e governo são

de condutas se realiza menos sobre do que através da população ativamente implicada num jogo concorrencial de novo tipo. De UPP em UPP, a contrainsurgência sem insurgência vai assim gerando o objeto do acordo tácito entre Estado, Empresas, Terceiro Setor, Comunidade, o simulacro de uma, como se diz no jargão piedoso, sociedade civil ativa e propositiva, o sonho de consumo no qual convergem as supracitadas entidades, regidas todas por uma mesma e nova racionalidade política, contra a qual ainda estamos aprendendo a lutar. Pois a Pacificação assim entendida não é mais um baluarte a ser tomado de assalto, porém um processo de autoempresariamento sem fim - pouco importando o grau de ficcão e padecimento no processo, bem como a predação concorrencial que ele necessariamente comporta. Do lado de cá também não pode mais haver alvo, o foco da paz armada nas favelas, conduzir-se como uma empresa de si mesmo, correndo de projeto em projeto, virou sim peixe dentro d'água, quem diria. Sem falar na sua armadura à prova de bala, o encaixe entre desenvolvimentistas sociais e protagonistas neoliberais - deixemos no ar o jargão. Dessa costura toda, dá noticia a dança dos papeis observada por Lívia e Dafne no artigo citado acima: "policiais que realizam atividades de educadores ou animadores sociais, oferecendo atividades esportivas, recreativas e de reforço escolar às crianças; gerentes de banco que funcionam como conselheiros de negócio e empreendimento, comerciantes que viram caixa de banco, líderes comunitários que gerenciam programas de governo, gestores públicos que transacionam empreendimentos privados". ambidestras. "A juventude desses locais tem um perfil curioso", observava em outubro de 2010 o principal formulador dessas políticas de contrainsurgência social, "o jovem tem grandes fragilidades, como baixíssima escolaridade, mas uma grande capacidade de iniciativa, de trabalhar em equipe e de fazer com que os outros trabalhem, tudo o que o mercado de trabalho valoriza hoje, e aprenderam tudo isso no mundo do tráfico, da ilegalidade". ${ }^{26}$ Como se vê, o "movimento" precisou apenas mudar de lugar, transpondo mais uma "fronteira de tensão"27, para manter o mesmo espírito, no caso, o capitalismo de projetos, que simplesmente não funciona sem a mobilização-implicação dos envolvidos em sua própria exploração. ${ }^{28}$

26. Citado por Maurilio Lima Botelho, "Crise urbana no Rio de Janeiro: favelização e empreendedorismo dos pobres" em Até o último homem (p.203). Que antes comenta o "programa CEBRAE nas Comunidades Pacificadas" - igualmente analisado em detalhe por Lívia Tommasi e Dafne Velazco, no artigo citado na nota anterior, que por sua vez destacam o mote do Programa: o empresário é o verdadeiro protagonista do território pacificado, só que ainda não sabia disso, pois todo aquele que se vira pra viver é empresário-, depois de lembrar que, tudo bem pesado, o modelo alardeado das UPPs pode ser Medellín, e a experiência de campo, Porto Príncipe, mas a linha instintivamente seguida é implantada pelos paramilitares cariocas, as milícias: "garantia repressiva de ordem e paz (até por toque de recolher) para fomentar a iniciativa privada e o desenvolvimento do mercado" (Ibidem, p.202) e se assim é, alcançar a fronteira da ilegalidade pouco muda quanto ao fundo, a circulação da mercadoria política, a compra e venda de proteção e seus derivados. Para a conversão da ilegalidade em mercadoria política a referência obrigatória são os estudos de Michel Misse, Crime e violência no Brasil contemporâneo (Rio de Janeiro, 2011, Lumen, em especial o capítulo 10).

27. Como diria Gabriel Feltran, estudando as relações entre política e violência em São Paulo, mais exatamente as estratégias de cooperação e conflito entre os diversos aparelhos de Estado e as "organizações" (fora e dentro da lei) com as quais disputa sua autoridade sobre o território. Fronteiras em tensão (São Paulo: Unesp, 2011).

28. Sobre a ideia de "projeto" no capitalismo de hoje, Luc Boltanski e Ève Chiapello Le nouvel esprit du capitalisme (Paris: Gallimard, 1999). Editado em português pela Martins Fontes WMF, 2009. 
O nosso Mr., quando reconheceu na abordagem carioca da pacificação reminiscências da doutrina americana da contrainsurgência, resumiu esta última em três comandos: "limpar, manter, construir"29. A limpeza dispensa comentários; a manutenção é óbvia, um posto polivalente de PMs idem; é na construção que está o x: como estamos vendo, uma construção eminentemente política, e portanto envolvendo relações mais ou menos coercitivas de avaliações e controle, de situações de mercado em âmbitos sociais redesenhados para produzir uma falsa mercadoria, que atende por diversos nomes, "cidadania", "inclusão", "participação" etc., cotadas, vendidas e compradas numa bolsa de valores e licitações, em cujos pregões atuam o amplo leque de entidades estatais, empresariais, movimentistas etc. Alguns pesquisadores batizaram essa terra de ninguém de "mercado da cidadania"30. A gran-

29. Trecho citado por Vera Malaguti Batista (Op. cit. p.77). [Se fosse para avançar o sinal ficaria difícil deixar de evocar os primórdios insurgentes do MST: "ocupar, resistir, produzir". Só a simetria entre os extremos bem que valeria os c.q.d].

30. Ludmila Costhek Abílio, Dos traços da desigualdade ao desenho da gestão: trajetórias de vida e programas sociais na periferia de São Paulo (Dissertação de Mestrado USP, 2005); José César de Magalhaes Júnior, O mercado da dádiva: formas biopolíticas de um controle das populações periféricas (Dissertação de Mestrado USP, 2006). Neste passo parafraseei em linhas muito gerais a já mencionada releitura do fantasma do Neoliberalismo que Pierre Dardot e Christian Laval, e pesquisadores associados, desentranharam de três aulas proféticas num remoto curso de Michel Foucault. Em duas palavras, o esquema parafraseado é mais ou menos o seguinte: O Neoliberalismo não seria nem uma ideologia, nem uma política econômica que devolveria aos mercados o que o Estado lhes roubara durante o breve parêntese do Welfarestate, nem um capitalismo tóxico ajustado à pureza consumada de sua matriz originária, nem uma patologia financeira cuja demasia seria curada por uma outra rodada de regulações comandadas por um Estado restaurado na plenitude de suas forças etc. Mas uma racionalidade, uma racionalidade antes de tudo política, mais precisamente, "governamental”, enfeixando "um conjunto de discursos, práticas, dispositivos que determinam um novo modo de governo dos homens segundo o princípio universal da concorrência", implicando este último pelo menos duas novidades maiores: primeiro, que uma tal concorrência, entre empresas-pessoas e sujeitos-empresas, não significa, de novidade agora é dupla: é que a porta de entrada deste mercado é a polícia, que por sua vez passou a ser apresentada, nada mais, nada menos, como um verdadeiro agente de transformação social ${ }^{31}$. Seja de que tipo for - econômi-

trivialmente, que doravante (mais de trinta anos...) o mercado devora toda a realidade, porém que a norma do mercado se estenda e se imponha para além do mercado; segundo, que para se realizar, tal princípio requer o consentimento ativo e participativo dos, justamente, concorrentes-empresa que assim são governados não contra ou malgrado sua liberdade mas através dela para que se conformem por si mesmos a certas normas. Dois minutos de reflexão, e não é difícil afirmar que de te fabula narratur, reconhecer a transformação da Universidade numa organização: ontem uma instituição estatutária, pesada, burocrática, hoje uma fábrica enxuta de indivíduos dóceis e atormentados por um ritual de avaliação que não pode avaliar nada, apenas produzir mais sofrimento, sobretudo nos mais adaptados, porque dessa usina cruel se exige que funcione como uma empresa embora obviamente ela não seja uma, daí a violência, por meio da qual, aí sim, se filia ao mercado real, pelo vínculo do trabalho intensificado, justamente - e nada a ver com "privatização" ou coisa que o valha, ou melhor, a privatização, se for mesmo necessário manter a ideia feita, vem a ser precisamente essa engrenagem estritamente gerencial de consentimentos e coerções, engajamentos e submissões indiscerníveis. Ainda há pouco, Lívia - e Dafne - não estavam dizendo coisa muito diferente, a saber: brigar contra as UPPs é uma luta vã enquanto não as compreendermos, como já dissemos e não custa insistir, como peças de um dispositivo de poder mais amplo cujo alvo é uma população territorializada a ser regulada por intermédio da construção política de mercados, e cujo objetivo é uma segurança muito mais que meramente securitária-policial.

31. Estes dois retratos de época, dois flagrantes deste nosso "presente humanitário", como diria Eyal Weiszman, foram pescados por Felipe Brito no atual consenso carioca. O mote da porta de entrada policial para a cidadania escande a trilha sonora de um filme comemorativo dos 200 anos da polícia militar do estado do Rio de Janeiro, documentário no qual um camburão sobe a ruela de uma favela, e depois de muito esforço e barulho estaciona, dele sai um policial que abre a caçamba da qual surge então um cordão cívico de médicos, professores, assistentes sociais etc. Não haveria vinheta mais expressiva do atual caráter bifronte do Estado brasileiro, face Sul Global, altamente concentrada no país, a um tempo social e penal: assistir e punir, bolsa tudo e encarceramento em massa dos sobreviventes dos autos de resistência. Quanto à promoção da polícia a protagonista da transformação social, a fórmula, mas não a ideia, que circula no ar do tempo, se deve a um dos modelos do Capitão Nascimento, primeira temporada. Cf. Até o último homem (cit. pp.80-1). Sobre as portas giratórias por onde entram e saem esses atores inovadores, por exemplo a militarização da fiscalização do comércio ambulante na cidade de São Paulo, entre outras dimensões do agregado composto por ordem social penal urbana e nova tecnologia política de gestão das cidades, ver Daniel Veloso Hirata, "A produção das cidades securitárias: polícias e políticas" Le monde Diplomatique Brasil, mar. 2012, pp.10-11. Ver ainda, Gabriela Moncau, "Kassab reforça o 
co, social, cultural ou uma combinação dos três, preferencialmente - o empreendedorismo dos pobres não é nenhuma esquina da história nacional, mas uma saída de emergência para o colapso da sociedade salarial no Brasil e no mundo. E como tal, um novo paradigma de governo das populações, e neste sentido sim, uma virada e tanto, que resultou na conformação de um exército de viradores de cujas fileiras seria mesmo um milagre descobrir a mais leve suspeita de insurgência. E, no entanto, mal nasce a manhã um intempestivo zelo contrainsurgente não cessa de multiplicar os meios de juntar os dois grandes objetivos desse novo paradigma de governo, e não só das populações das famigeradas aglomerações subnormais, Paz e Oportunidade ${ }^{32}$. A Pacifica-

Estado policial em São Paulo", Caros Amigos, Jul. 2011.

32. Na excelente formulação de Fábio Magalhaes Candotti, Em defesa da juventude: a participação como meio de governo (tese de Doutorado UNICAMP, 2011). Voltaremos ao binômio, como se dizia na Ditadura, quando o tal binômio era outro, Segurança e Desenvolvimento. Resta saber o que restou desse binômio sinistro. PS. Poucos dias depois de redigir esta nota a Presidente da República, em seu discurso de final de ano (30 de dez, 2013), declarou que o seu governo se tornara há algum tempo o alvo preferencial de uma "guerra psicológica adversa" movida por "alguns setores", que "instilam desconfiança, em especial desconfiança injustificável". Os dois jornalões de São Paulo reagiram. Em matéria editorial de $1^{\circ}$ de jan. de 2014 . O Estado de São Paulo registrou a linguagem estapafúrdia e descabida sem dar notícia, porém, de sua procedência de origem mais do que comprometedora. Já o colunista da Folha de São Paulo, Vinicius Torres Freire (31 de dez. de 2013, p.A12), destacou a incongruência de uma veterana da luta armada, pela qual pagou o preço da tortura e da prisão, recorrer àquela relíquia da Doutrina da Segurança Nacional, lembrando, por exemplo, que o Ato Institucional No 14, baixado pela Junta em 1969, legalizava a pena de morte para crimes como "guerra psicológica", revolucionária ou subversiva, como se dizia então, concluindo: "é com pesar que a gente se pergunta o motivo de a presidente ter piorado ainda mais seus discursos assintáticos com essa mancha de péssima memória”. Se estamos no caminho certo, a chave do enigma não é nenhum viés autoritário banal - e ainda que fosse, não explicaria o lapso histórico inquietante -, mas sim a dimensão de poder - concentração, expansão e projeção - inerente à ideia histórica de Desenvolvimento, que implica, para além da mera tautologia da acumulação para continuar acumulando, a compulsão ao catching up, a ascensão a todo custo (quem não subir, cai) na escala hierárquica e assimétrica do capitalismo como sistema internacional. A prova dos nove veio com a Ditadura, que fundiu desenvolvimentismo e contrarrevolução preventiva. Diante desta ex- ção e seus Inimigos: demos mais uma volta no parafuso da emergência, e nada. Sem os tais insurgentes que mal e mal imaginamos, o que será de nós pacificadores, fardados e à paisana? Até que o tiroteio voltou, depois de Junho. Como vimos, segundo a fantasia punitiva de que partimos, graças à aliança inusitada, porém objetiva, entre a grande e destrutiva insubordinação das ruas e o espectro do inimigo titular da Pacificação, o Crime, organizado ou não.

A perfeição quase mecânica do encaixe se deve justamente à ordem temporal invertida. Os Pacificadores, que obviamente não poderiam saber que suas campanhas seriam incorporadas vinte anos depois ao repertorio da contrainsurgência, também sonhavam para frente ${ }^{33}$. Mas ao ligarem os pontos que a ninguém ocorreria ligar nas semanas do quebra-quebra mais intenso, pelo menos, ao pressentirem o sinal de uma virada, acertaram, embora no que não viram. A palavra insurgência nem de longe é frequente no vocabulário político brasileiro. Mesmo quem se politizou tendo lido o México Insurgente de John Reed, raramente a empregou, se é que o fez. Mesmo no auge da Guerra Fria e, portanto, em tempos de difusão

periência traumática, armou-se o mito compensatório dos Anos Dourados que teríamos vivido nos anos JK. Logo veremos se a Doutrina da Pacificação - para adotarmos a fórmula exata de Eduardo Tomazine - terá absorvido ou não, a da Segurança Nacional, que por sua vez já não se distingue mais de sua versão urbana, patente no Urbanismo Militar, assinalado páginas atrás.

33. Uma analogia arriscada talvez ajude, não tanto a ideia, mas a imagem da peripécia que temos pela frente. Atribui-se a Teodoro Petkoff - que por mais renegado que seja, ex-comunista e ex-guerrilheiro, não padece da cegueira ideológica dos seus aliados esquálidos - o dito segundo o qual a simples chegada de Hugo Chávez ao poder, e ainda pela mais inquestionável das vias institucionais, foi não obstante o suficiente para desencadear uma verdadeira Contrarrevolução, diante da qual viu-se na contingência de providenciar uma correspondente Revolução, até então inexistente. Mutatis mutandis, a nossa presumida insurgência deu o ar de sua graça, pelo menos aos olhos das várias tribos de branco, bons anos depois dos Contra botarem o bloco na rua. 
da terminologia gringa da Segurança Nacional, exterminava-se subversivos, e não insurgentes. Os movimentos de protestos que tomaram as ruas e praças do mundo a partir da queda de Mubarak, em fevereiro de 2011, estavam coalhados de indignados, mas que se saiba nenhum insurgente. Mesmo em Seattle, novembro de 1999, quando o quebra-pau voltou às ruas atestando que a grande tradição norte-americana de desobediência civil - e seus mártires da manifestação pacífica - batera no teto, havia sim um número crescente de autodenominados anticapitalistas, mas nem mesmo a reestreia com novo script dos Black Blocs reconheceu-se insurgente, mesmo porque, como se diz à esquerda e à direita, eles não falam, só quebram. Por fim o marco zero de todo o novo período, o levante Zapatista de $1^{\circ}$ de janeiro de 1994 . Na acepção trivial do termo, os Zapatistas de fato se insurgiram contra o governo federal mexicano, mas em nenhum momento cogitaram tomar o poder, pela simples razão que julgavam ser esta a via real para não transformar o mundo, e nisto bifurcaram no tronco das insurgências históricas na América Latina, não obstante se organizassem também, na defesa de suas municipalidades autônomas, na forma de um exército de libertação nacional. Pode ser até que a palavra se encontre em seu imenso acervo de manifestos e comunicados, mas certamente não a coisa.

As avaliações provenientes das mais diversas fontes oscilam entre 10 e 15 milhões de manifestantes em mais de 500 cidades. Enquanto não dispusermos de uma razoável coleção de relatos de todas as procedências, sobretudo das mais improváveis, continuará soterrada a memória viva do maior protesto de massa da história brasileira, com esta peculiaridade igualmente divisora de águas, a de que ele foi rigorosamente autoconvocado, ao contrário de episódios altamente coreografados, como as Diretas Já ou os Caras Pintadas. Tão cedo não saberemos quem, quantos, em que circunstância, a que altura dos acontecimentos, poderiam se reconhecer no performativo - na sua acepção linguística originaria, para início de conversa: fazer coisas com palavras - "insurgente". De novo: as visões cariocas da Doutrina da Pacificação mostraram que não se trata de mera preferência terminológica. $\mathrm{Na}$ minha documentação impressa, que infelizmente está muito longe de ser exaustiva, apenas numa publicação de novembro de 2013, a jornalista Lena Azevedo, e alguns de seus entrevistados, recapitulam a onda social que deixou no seu rastro centenas de novos coletivos ao longo de cinco meses de altos e baixos, como uma "insurgência nas ruas", "insurgência social", "insurgência popular"34. Não é prova de nada, mas pode vir a ser. Resta a novidade de sua redescoberta de agora, porém sentido e referência não podem mais ser o mesmo. A única evidência da pista intrincada que seguimos até aqui foi o aviso de incêndio dado pelos pacificadores. Mas até aqui nosso encontro com o espectro da insurgência foi mero efeito dedutivo de uma triangulação de medos e ameaças na qual um dos termos só a chamava pelo nome por ser contra. Ou do acaso. Convidado pela socióloga Isleide Fontenelle em agosto de 2013 a também me exprimir sobre os acontecimentos de junho num ciclo de palestras da FGV São Paulo, notei que, em quatro falas programadas, duas traziam insurgência no título, não sei se empregadas em sua acepção corrente ou não, e por quê, pois até então, como observado, a palavra mal circulava no Brasil. Infelizmente não pude ouvir

34. Lena Azevedo, "O Estado contra o povo", Caros Amigos, n. 200, nov. 2013, pp. 20-21. 
nenhuma das intervenções. Pelo sim pelo não, achei que seria uma boa ocasião de testar minha hipótese quando chegasse minha vez em outubro.

\section{3.}

As coisas estavam nesse pé quando me deparei com a tese do antropólogo James Holston, que estuda periferia em São Paulo desde os anos 80 - tendo aliás, nesse meio tempo, publicado um livro muito conhecido sobre as notórias segregações socioespaciais multiplicadas pelo urbanismo de Brasília, a utopia urbana que virou pesadelo ${ }^{35}$. A tese desnorteia, não menos que o título, no meu desconhecimento de outras acepções possíveis do termo no repertório político e intelectual americano: Cidadania insurgente: disjunções da democracia e da modernidade no Bra$s i{ }^{36}$. Há três décadas a periferia de São Paulo está povoada de cidadãos "insurgentes" e não sabíamos, ou melhor, não sabíamos que seus moradores fora de esquadro também podiam ser chamados assim. Assim como? A definição de Holston é peculiar, por isso a transcrevo renunciando ao comentário que ela sem dúvida está pedindo: "a insurgência define um processo que é uma ação na contramão, uma contrapolítica, que desestabiliza o presente e o torna frá-

35. James Holston, A cidade modernista: uma crítica de Brasília e sua utopia. São Paulo: Cia das letras, 1993.

36. São Paulo, Cia das Letras, 2013. A edição original americana é de 2008. gil, desfamiliarizando a coerência com que geralmente se apresenta; insurgência não é uma imposição de cima para baixo de um futuro já organizado. Ela borbulha do passado onde as circunstâncias presentes parecem propicias a uma irrupção"37. Desde que a entendamos, convenhamos que dará muito pano para manga. Pois, segundo seu autor, nela se enquadram tanto a "insurgência democrática nas periferias urbanas do Brasil", no seu confronto com o regime de cidadania dominante historicamente, como o nazismo (que sem dúvida "lançou um movimento de cidadania insurgente na Alemanha") ou a direita fundamentalista norte-americana - e nesses termos, o levante zapatista me pareceria um candidato natural, ainda mais por emendar na insurgência mexicana propriamente dita, dos tempos de Zapata e Villa. Assim abrangente, o sentido de "insurgente" não pode ser mesmo normativo, como adverte o autor: "cidadanias insurgentes não são necessariamente justas ou democráticas, populistas ou socialistas. Cada caso deve ser avaliado". No caso brasileiro, mas não só, há ainda um sentido suplementar de enfrentamento e combate, expresso já na denominação do regime de cidadania oponente, que o autor batizou de "entrincheirado". Também não saberia dizer se seu uso é corrente ou não na terminologia sociológica norte-americana. Não me parece implausível presumir que a inovação vocabular do autor tenha se dado na ordem inversa das metáforas: uma vez identificado o regime de cidadania desigual como uma linha de barricadas e fortificações edificadas para a defesa de usurpações e privilégios, parece lógico e sob medida a denominação em termos de assalto a uma praça forte para quem se insurge contra essa ordem de desigualdades

37. Ibidem, p.63. 


\section{instauradas.}

O desenvolvimento das periferias urbanas - mas não periferias quaisquer, mas as autoconstruídas - é descrito assim como um confronto entre duas cidadanias, uma insurgente e outra entrincheirada. Não posso obviamente me deter no tema polêmico da autoconstrução embora ele seja central na argumentação do autor, a ponto de lhe permitir justificar de forma original a ênfase no consumo das classes trabalhadoras, estratégico no atual arranjo apaziguador de poder. Quando os trabalhadores pobres se viram forçados a morar em regiões distantes, em condições precárias e ilegais, no meio do mato como ainda se diz, "tiveram de construir suas próprias casas, se organizar para conseguir serviços básicos e lutar para manter suas casas em meio a diversos conflitos, frequentemente violentos, pela propriedade dos imóveis. Ainda assim, em algumas décadas eles urbanizaram esses bairros e melhoraram de forma notável suas condições de vida. Além disso, como os moradores passaram décadas transformando barracos em casas de alvenaria mobiliadas, decoradas e bem acabadas, essa autoconstrução se tornou um domínio de elaboração simbólica. Ela expressa narrativas coletivas e igualitárias de estabelecimento das periferias e narrativas individuais de realizações desiguais. Dessa forma, a autoconstrução transformou as periferias em espaços de futuros alternativos, produzidos nas experiências de se tornar proprietário, de organizar movimentos sociais, de participar de mercados consumidores e de fazer julgamentos estéticos sobre as transformações das casas ${ }^{38}$. Desse modo, Holston poderá mostrar que desde a década de 70, as classes trabalhadoras vêm formulando nas periferias

38. Ibidem, p.29. das cidades brasileiras "uma cidadania insurgente que desestabiliza o entrincheirado". E assim argumenta que "as provações da moradia ilegal, da construção de residências e dos conflitos de terras" forneceram "o contexto e a substância de uma nova cidadania urbana". Pois então: essa nova cidadania urbana é assim fruto de uma insurgência local que desestabilizou os privilegiados a partir dos lugares históricos na diferenciação igualitária - os direitos políticos, o acesso à terra, a igualdade, o servilismo ${ }^{39}$. Como se está percebendo, o nervo dessa insurgência - inusitada apenas no emprego inesperado da palavra - é urbano, graças a ela os trabalhadores pobres garantiram, nada mais nada menos, que seu direito à cidade, hoje no epicentro da convulsão nacional que se sabe.

E ganharam seu direito à cidade - nesta acepção muito peculiar em que gravita na órbita de uma insurgência - "adquirindo direitos políticos, tornando-se donos de imóveis, usando a lei a seu favor, criando novas esferas públicas de participação e se transformando em consumidores modernos". Uma paradoxal insurgência dentro da ordem portanto, que Holston descreve como um emaranhado corrosivo e desequilibrador de persistências e resistências em que o insurgente representa sim uma ruptura embora sem dúvida perpetue atributos da cidadania entrincheirada historicamente dominante, como "o significado da propriedade fundiária, a prática da legalização do ilegal e a norma do direito de tratamento especial"40. Imagina assim poder evitar o que considera um falso dilema armada pelos estudiosos dos movimentos so-

39. Ibidem, p.34.

40. Ibidem, p.36. 
ciais surgidos nessa onda de cidadania que está chamando de insurgente: no corpo a corpo com o Estado, a oscilação recorrente entre resistência e cooptação, mobilização e institucionalização. Pois aprendeu com a teoria feminista "a ver que a agência humana também produz entrincheiramento, persistência e inércia”. Seria o caso de acrescentar, sem maiores comentários por hora, que nós também aprendemos, na observação dos altos e baixos da galáxia movimentista brasileira - mas não só ela - que a praga da burocratização dos movimentos, ou seu entrincheiramento como preferiria dizer Holston, não é uma patologia evitável mas um desdobramento de seu próprio êxito na condução do social ${ }^{41}$. Não é verdadeira a impressão de

41. Tampouco me parece ser o caso de recapitular, em contraponto, os capítulos correspondentes da tradição crítica brasileira no que concerne, por exemplo, os vínculos de reprodução da força de trabalho e moradia popular na origem dos novos movimentos sociais. Para o sonho popular imemorial da casa própria, e um apanhado da literatura crítica a respeito na virada dos anos 70 para os anos 80, ver Eder Sader, Quando novos personagens entraram em cena: experiências, falas e lutas dos trabalhadores da grande São Paulo (São Paulo: Paz e Terra, 1988, pp.99-114). Seja como for, a ênfase de Holston é na cidadania urbana e na mobilização urbana e não nos novos movimentos sociais - e sua extensa e amplamente conhecida literatura, o que muda muita coisa, como estamos vendo com a introdução da ideia de insurgência nesse contexto movimentista. Não seria menos interessante, também no âmbito daquele marco zero histórico, procurar o encaixe possível dessa denominação assim tão extemporânea - não se trata de mera sinonímia para rebeldia, resistência, contestação etc. - no debate da época acerca da identidade do novo sujeito que estaria emergindo, popular, autônomo, coletivo etc. Novamente impressiona o curto-circuito, ao ver assim o consumo de utilidades e objetos domésticos associado à conformação de uma subjetividade insurgente. E novamente a explicação se encontra na experiência histórica da autoconstrução, a ponto de quase se poder falar de um sujeito autoconstruído como tal, e na periferia, por certo. "Quando passaram a construir e montar suas casas", afirma Holston, "as classes trabalhadoras assumiram as identidades sem precedentes de produtores e consumidores da vida urbana. Suas casas se tornaram textos legíveis que atestam essa mudança [na subjetividade], performances arquitetônicas tanto da aquisição de bens individuais e da competição por status como drama coletivo de produzir nas próprias periferias ao se apropriar e transformar o solo mesmo da cidade", Ibidem, p.27. Ver ainda, no capítulo 7, "Cidadãos urbanos", uma análise do modo pelo qual a novidade que a argumentação por direitos representou para os movimentos sociais urbanos permitiu que esses transcendessem a referência específica à lei, passando que James Holston estaria redescrevendo mais uma vez a grande onda democrática dos anos $80^{42}$, agora pelo prisma inusual de cidadania dita insurgente - a seu ver, entre outras coisas, a vitória eleitoral de 2002 poderia ser interpretada, para além do triunfo da política democrática como a conquista de "uma cidadania insurgente de justiça social" - por certo também é esse o caso, mas de fato está dizendo muito mais, que o impulso predominante na origem dessa reviravolta na paisagem brasileira procede mais especificamente de uma longa batalha pela democratização do solo urbano, travada por uma geração de cidadãos insurgentes, geração que soube criar um acesso sem precedentes a seus recursos ${ }^{43}$. Vale a pena olhar um pouco mais de perto para esse "novo tipo de direito adquirido sobre a cidade". Afinal a explosão de Junho se deu em torno de um de seus componentes fundamentais, a livre circulação,

a significar uma "mudança na subjetividade: ou seja, a articulação era como uma performance que muda o status dos atores", Ibidem, p.312. Pouco antes, uma inesperada analogia ao introduzir a "guinada para os direitos" nos movimentos sociais urbanos: "os argumentos baseados nos direitos motivaram os moradores das periferias não só porque forneciam uma estratégia com a qual lutar contra as grandes desigualdades e deficiências que enfrentavam em sua vida na cidade. Os discursos de revolução armada também fazem isso, Ibidem, p.311. Se assim é, deve também valer outra analogia parcialmente esclarecedora da preferência do autor pelo repertório antagonístico da insurgência, mesmo que esta culmine na trincheira da propriedade privada: tudo se passa como se fosse necessário um suplemento de energia insurgente para transformar a condição de mero posseiro dependente de favores na de proprietário portador de direitos universalmente reconhecido.

42. Como se diz na historiografia do período, sobretudo quando se trata de recuperar a história do petismo e o surgimento do lulismo. Para Lincoln Secco, por exemplo, aquele partido novo que buscava sua vez e voz na vida brasileira só começaria a ser ouvido "depois da ameaça de uma verdadeira revolução democrática que de 1984 a 1989 sacudiu o país, embora não o suficiente", História do PT (São Paulo: Ateliê, 2011, p.76). Para um apanhado do que também chama de "primavera democrática" ver André Singer, Os sentidos do lulismo, cit., capítulo 2.

43. James Holston, Ibidem, pp. 349-50. 
sem a qual uma cidade não existe, como se podia ler desde 2010 no grafite-manifesto do MPL: "Pule a Catraca! Passe Livre Já! Uma cidade só existe para quem pode se movimentar por ela." ${ }^{44}$ Direito adquirido pela bizarra insurgência da autoconstrução, noves fora a força de trabalho não paga empregada nela, mas evitemos a página virada

44. Para um comentário dessa inscrição sob a via elevada numa das avenidas mais movimentadas de São Paulo, ver Teresa Caldeira, "Inscrição e circulação”, Novos Estudos, n. 94 (São Paulo: CEBRAP, novembro de 2012, p.58). "Esse tipo de manifesto urbano afirma o desejo de se apropriar da cidade percorrendo-a em todas as direções e, reconhece a dificuldade de fazer isso devido ao custo dos transportes coletivos. Portanto, ocorre aí, ao mesmo tempo, a identificação de uma injustiça social e a reivindicação do direito à cidade" (Ibidem). A autora com certeza reconheceria na utopia bem tangível de pular a catraca a cifra de um novo regime de cidadania insurgente, na acepção que lhe deu Holston e estamos tentando adivinhar. Alargamento na disputa perene entre insurgentes e entrincheirados, ou um passo novo? Penso que as duas coisas, pelo que pude depreender do que disse a autora à Folha de São Paulo (23 de junho de 2013, Ilustríssima, p.3), no auge das manifestações de junho, para as quais antevia um desfecho semelhante aos motins que incendiaram as periferias francesas no outono de 2005. (Na mesma reportagem, de Cassiano Elek Machado e Graciliano Rocha, indagado a respeito desse possível parentesco, o sociólogo francês Sebastian Roché, autor de um livro sobre aquelas revoltas de 2005, unanimemente consideradas as mais extensas e intensas na história contemporânea da França - Le frisson de l'émeute: violences urbaines et banlieues (Paris: Seuil, 2006) -, confessa não ver muitos pontos de comparação: na França, diz ele, "foram os pobres destruindo os meios de vida dos pobres. A burguesia ou o governo não foram os alvos. Nenhum espaço de poder foi sitiado ou tomado. Ninguém se aproximou, por exemplo, do parlamento ou da sede do governo [como ocorreu no Brasil]". Faltaram os 20 centimes. Trocadilhos à parte, seria muito otimista imaginar que a "cidadania insurgente" no Brasil teria queimado - mas por aqui muita coisa também pegou fogo - a etapa autodestrutiva da raiva?). Seja como for, logo veremos, pois um segundo round está à caminho, com data marcada e tudo. Veremos também em que direção se terá ampliado o repertório da cidadania insurgente. Aliás já era o caso no artigo citado: pixadores e grafiteiros, skatistas, rappers e traceurs, bem como praticantes de break, ao circularem incessantemente por toda a São Paulo, outra coisa não fazem, através dessas performances "agressivas, ilícitas, arriscadas" do que se insurgirem - nos termos de Holston - contra o regime de "entrincheiramento espacial" a que a cidade foi submetida pelo condomínio que conduz a máquina urbana de crescimento. O sistema de enclaves fortificados no qual São Paulo se converteu - um real e sinistro emaranhado de entrincheirados e insurgentes - já teria sido estudado no livro bem conhecido de Teresa Caldeira, Cidade de muros: crime, segregação e cidadania em São Paulo (São Paulo: Edusp/Ed.34, 2000). dessa polêmica sem fim ${ }^{45}$.

Pois na contramão dos clássicos, o que Holston está dizendo sobre as classes trabalhadoras, não só no Brasil, mas em todo o Sul do planeta, é que seus integrantes se tornaram novos cidadãos - e urbanos, para começar "não por meio das lutas trabalhistas, mas pelas lutas pela cidade". Longe das fábricas, longe dos patrões. É bem conhecida - mas nem sempre lembrada na hora certa ${ }^{46}$ - a explicação de Florestan Fernandes para a truculência bárbara para as lutas de classe no Brasil, alimentada pelo verdadeiro medo pânico dos dominantes ante a menor aspiração de desafogo dos setores populares. No capitalismo dependente, como se dizia então, a guerra social sempre se travou entre duas categorias, os "possuidores de bens", que monopolizam todos os benefícios do sistema, e os "não-possuidores de bens", na sua grande maioria "os condenados do sistema”. Essa brutal assimetria condena os despossuídos a gravitar num universo de "mínimos políticos", assim como desloca para a margem o conflito entre capital e trabalho, e com ela a expectativa de direitos, indisponíveis para os de baixo no mundo exclusivo dos proprietários. Escapar assim da desclassificação social, só pela porta estreita do assalariamento. Daí, concluía Florestan, para escândalo de seus correligionários socialistas, "a identificação positiva com a proletarização, vista como ascensão social e também como um privilégio,

45. A propósito dessa querela infindável, Francisco de Oliveira, "O vício da virtude: autoconstrução e acumulação capitalista no Brasil”, Novos Estudos, no74 (São Paulo: CEBRAP, março de 2006). Acompanha a transcrição do debate que se seguiu à palestra original.

46. Salvo por Plínio de Arruda Sampaio Jr., em cuja reconstituição e citações estou me apoiando: Entre a nação e a barbárie: os dilemas do capitalismo dependente (Petrópolis: Vozes, 1999, pp. 142-150). 
a superestimação do estilo de vida operário etc. Mecanismos pelos quais se concretiza a conciliação dos condenados do sistema com sua ordem sócio-econômica"47. A insurgência dos pobres urbanos segundo Holston inverteu esse quadro de redenção pelo trabalho regulamentado, herdado do imaginário trabalhista forjado na Era Vargas, como se sabe, sem precisarmos reabrir toda a biblioteca a respeito da "cidadania regulada", na frase famosa de Wanderley Guilherme dos Santos, uma cidadania embutida nas profissões e ocupações reconhecidas e definidas por lei, e por isso restrita e perpetuadora de desigualdades, porém ancorada no mito libertador da carteira de trabalho. ${ }^{48}$ As leis trabalhistas, prossegue o argumento, constituíram sem dúvida um horizonte visível de direitos, mas nem por isso a fábrica deixava de ser um espaço "marcado por um profundo sentimento de frustração, fracasso, divisão e dependência”, e neste aspecto, paradoxalmente o menos propício para o desenvolvimento de uma cidadania da classe trabalhadora, e ainda mais paradoxalmente, em contraste com as periferias ilegais, autoconstruídas e remotas, que por sua vez, longe dos olhos do Estado, dos empregadores e do trabalho assalariado, foram se convertendo em espaços autônomos abertos por uma cidadania de fato antagônica. Esse o resumo da insurgência: "exatamente em oposição ao regime fabril, a conquista de uma casa própria se tornou uma emancipação da dominação do empregador e da regulamentação do Estado para os pobres urbanos e, como tal, uma forma de reavaliar seus lugares pessoal e

47. Apud Plínio de Arruda Sampaio Jr. (cit., p.146).

48. Wanderley Guilherme dos Santos, Cidadania e justiça (Rio de Janeiro: Campus, 1979, $2^{a}$ edição, 1987). Para o comentário crítico de Holston, op. cit. pp.252-257. coletivo na sociedade brasileira"49.

Enquanto esteve na linha de frente da ofensiva popular que ganhou corpo com o recesso da Ditadura, terá sem dúvida contribuído para corroer o prestígio do assalariamento como via de acesso a direitos e fator de identificação com a sociedade dos proprietários dos meios de produção. Até que o Estado e o complexo imobiliário-financeiro entraram em campo dispostos a enfrentar, como se diz, o déficit habitacional encerrando o ciclo épico da cidadania insurgente. A mesma cidadania insurgente que desacreditara as promessas do assalariamento via-se agora engolida por um outro regime de conversão do direito à moradia em simples acesso via mercado subsidiado à propriedade de um imóvel, refazendo assim, nos termos de nosso autor, o emaranhado de entrincheirados e insurgentes, ou na chave atual, cadastrados por movimentos credenciados e os relegados de sempre, no fundão cinzento das periferias consolidadas. ${ }^{50}$ Muitas leis e instrumentos urbanísticos depois, mais ainda um Ministério da Cidade, um Estatuto da Cidade, planos, conselhos, fundos variados etc., reunidos todos os capítulos da "cidadania democrática insurgente", cujo triunfo James Holston tes-

49. James Holston, (cit.) p.257.

50. Como nos tempos da Ditadura, a ideologia compensatória da casa própria voltou com tudo, e como toda ideologia que "pega", com forte apoio na realidade, como admitem os primeiros críticos desse engodo de massa chamado Minha Casa Minha Vida, Mariana Fix e Pedro Arantes, "Como o governo Lula pretende resolver o problema da habitação", Correio da Cidadania, julho de 2009. Mas ao reapresentarem a casa própria como o derradeiro "bastião da sobrevivência popular", e tudo o que daí decorre na ampla gama de significados reais e simbólicos da noção onipresente de segurança - da velhice com teto à proteção contra os despejos, passando pela segurança simbólica dos laços de solidariedade de bairro -, não deixam de assinalar mais um deslocamento na retaguarda dos entrincheirados populares, bem como o rebaixamento do antigo horizonte de "futuros alternativos", pois a casa própria que o salário nunca pode comprar hoje é um bem ofertado no mercado de dádivas do governo. 
temunhou numa noite de novembro de 2002 na Avenida Paulista, "os pobres foram aconselhados a parar de fazer autoconstrução e mutirão, meios arcaicos de se produzir moradia no mundo de mercadoria para se tornarem compradores, a prazo e com certo subsídio da mercadoria-moradia"51. Reviravoltas como esta, em que o fundo falso de um processo se comprova na verdade de seu desfecho, não se improvisam. Foi preciso muitos mandatos, ONGs, gabinetes, administrações, universidades, e sobretudo muito empenho sincero de trabalhadores sociais envolvidos na elaboração e aplicação das mais diversas políticas públicas para canalizar as lutas populares - como o nome indica "canalizar" como se retifica um rio turbulento: essa onda participativa-governativa acabou orientando "a ação direta da desobediência civil (o ciclo das ocupações) na direção da prática responsável de quem faz estatutos e participa de conselhos (o ciclo das leis)"52. Ao nos despedirmos da Cidadania Insurgente, seria o caso de dizer que ao se encerrar seu ciclo, ela teria sido suplantada por um novo regime de Cidadania Regulada para o qual ainda não temos nome - quem sabe "totalmente administrada", ou seu equivalente numa sociedade periférica madura, equipada até com multinacionais próprias, que deixou de

51. Pedro Fiori Arantes, "Da (Anti)Reforma Urbana brasileira a um novo ciclo de lutas revolucionárias nas cidades", in Jornadas de Junho: A Revolta Popular em debate. Rio de Janeiro, Instituto Caio Prado Jr., 2014, pp. 41-66. Também publicado no site Carta Maior.

52. Idem Ibidem. Não se trata de negar, por exemplo, que o Estatuto da Cidade, nos termos em que Holston redescreve todo o processo, seja o resultado dos "movimentos de cidadania insurgente iniciados nos anos 1970", Cidadania insurgente (cit., p.376), mas de compreender como "aquilo deu nisso". Como um autor, que soube redefinir tão bem a dimensão insurgente da autoconstrução produtora de espaços autônomos na periferia, interpretaria as sementes de "entrincheiramento" germinando num programa dito democrático-popular de Reforma Urbana? ser subdesenvolvida, como se dizia nos tempos em que a miragem do desenvolvimento funcionava, sem com isso integrar-se ao condomínio fechado do sistema mundial de poder e acumulação. ${ }^{53}$

Mas aí veio Junho. Nem seria preciso esperar alguma manifestação de Holston a respeito, para sabe-lo convencido, e reconfortado, de que sua Cidadania Insurgente foi para as ruas em junho. De fato, em entrevista recente, convidado a avaliar o novo fenômeno dos "rolezinhos", não só reconheceu prontamente na velocidade de propagação destes últimos a impregnação do Espírito de Junho, pois tem a ver com ocupação de espaço e circulação, como lembrou que a cidadania insurgente está presente no Brasil há quase meio século, só que esquenta e esfria dependendo de circunstâncias imprevisíveis: e junho foi um dos momentos em que a chapa ferveu ${ }^{54}$. Ninguém dirá que não, ainda que não saibamos ao certo o que devemos entender por insurgência nas presentes circunstâncias. Todavia, se nos mantivéssemos fiéis aos termos do próprio autor, seria o caso de dizer que a novidade da conjuntura resultaria precisamente não da persistência do antigo e recorrente impulso antagonista, mas do choque, na intensidade que se viu, entre os dois regimes de cidadania, o insurgente e

53. Se tudo isso faz algum sentido, na mesma medida torna-se até mais intrigante - por não ser sequer imaginável uma ressurreição da cidadania de tipo varguista, regulada pelo vínculo que atava profissão legalizada, contrato e direitos - a aposta de André Singer de que a redução da pobreza, amenizada pelo sistema de transferência diretas, se dará de fato pela incorporação do subproletariado ao que chama de "cidadania trabalhista". Ver além do citado Os sentidos do lulismo, a entrevista a Luís Brasilino, "Novas expressões do conservadorismo brasileiro", Le Monde Diplomatique Brasil, outubro de 2012, p.21.

54. “'Rolezinhos' têm origem na luta pelo espaço urbano”, entrevista de James Holston a Eleonora de Lucena, Folha de São Paulo, 19 de jan. de 2014, Cotidiano C8. 
o entrincheirado. Podemos duvidar, mas desse entrechoque pode estar surgindo o oponente com o qual sonhavam os planejadores de uma contrainsurgência no vazio. Alguns sinais desse choque que viria e começou a acontecer poderiam ser rastreados no último capítulo do livro que só agora pudemos ler, e depois de junho, para variar, o capítulo dos perigos. Ao longo do qual nos deparamos com um pequeno inventário dos espaços de confronto entre o insurgente e o diferenciado, a começar pelas incivilidades cotidianas a permear os encontros públicos. A incivilidade é sempre a incivilidade do outro - entendendo por civilidade, como relembra Holston, um código de comportamento associado à participação na vida pública -, e esse outro de agora é mesmo o Outro, aquela nova geração de insurgentes cujo acesso sem precedentes aos espaços públicos e seus recursos gerou um "clima de medo e incivilidade”, responsável por sua vez pelo "visual sitiado" (Mike Davis), que foi se alastrando pelas grandes aglomerações urbanas brasileiras. Mais uma vez, voltaremos.

4.

A primeira vez que me deparei com esse provável sinal de uma mutação a caminho foi num pequeno e profético artigo de Sílvio Mieli, publicado na última semana de julho de $2013^{55}$. Sem exagero, quase dois meses depois da explosão de junho, foi uma das primeiras tentativas realmente ori-

55. Sílvio Mieli, “Black blocs”, Brasil de Fato 25-31 jul., 2013, p.3. ginais de conceptualização daqueles acontecimentos, nos quais até o mainstream da ciência política - com perdão da redundância - reconhecera "a mais expressiva, surpreendente e rápida vitória popular da nossa história”, enquanto lideranças históricas não menos expressivas desse ambíguo campo popular vitorioso ainda teimavam, e teimam, em ver naquilo tudo "tão somente uma revolta" [revolta é sempre mera revolta], a "indignação" de uma juventude sem projeto, sem nem mesmo saber no que tudo isso vai dar etc., sem falar na linha justa de sempre, reconfortada pela enésima demonstração de que o esquerdismo é mesmo uma doença infantil ${ }^{56}$.

Se eu entendi bem, Sílvio Mieli teria dito mais ou menos o seguinte. Antes de tudo, como sugere de saída a etimologia latina da palavra, insurgir-se é levantar-se, pôr-se de pé, mas também surgir, vindo do fundo, como algo submerso subindo à tona. Neste primeiro sentido, posso acrescentar que, até onde minha vista alcança, muita leitura dos acontecimentos no calor da hora seguiu espontaneamente essa trilha: sair à rua seria um dia entendido como insurgência pelo simples fato de que as pessoas estavam se levantando do sofá diante da televisão - e

56. Seria historicamente injusto não assinalar entre a ciência política estabelecida e a esquerda da pesada, o juste milieu ocupado pelo cientista político que decifrou um dos sentidos do lulismo enquanto expressão política de todo um amplo setor da população pobre brasileira "destituído das condições mínimas de participação na luta de classes", André Singer, Os sentidos do lulismo: reforma gradual e pacto conservador (São Paulo: Cia das Letras, 2012, p.77), o qual também reconheceu no "levante urbano desencadeado pelo Movimento Passe Livre (MPL)", não só uma "vitória extraordinária ao conquistar a redução do preço das passagens do transporte coletivo em São Paulo e em tantas outras cidades", como admitiu que "nunca na história recente do país - e talvez nem na antiga - camadas populares tenham se levantado em tal proporção", "Esquerda ou direita?”, Folha de São Paulo, 22 de jun. de 2013, p.A2. Mesmo com as ressalvas de praxe quanto à democracia, partidos e sindicatos, foram dois "levantes" numa única coluna. 
já ouvi muito engraçadinho dizer que Maio de 68 só aconteceu porque na França as pessoas ainda não dispunham da televisão como um bem de consumo de massa, onde descarregar o mal-estar de uma sociedade na qual não se morria mais de fome, mas em compensação se morria de tédio ${ }^{57}$. Daí a gracinha suplementar perpetrada por outra sumidade, segundo a qual a população foi para a rua porque se entediava ${ }^{58}$. Mas voltemos à insurgência de Junho

57. É preciso reconhecer entretanto, que no piloto automático da esquerda que ainda não se conformou com a evidência de que manifestações de massa podem acontecer sem organizações de massa, dogma da pirâmide e sua base que ainda compartilha com a direita que se julga vitoriosa porque a "sua" mídia pautou o povaréu na rua assim que se recuperou da barriga comida nos primeiros atos, a poltrona vazia é apenas uma natureza morta, não constam sequer "os motivos que fizeram milhares de pessoas se levantarem do sofá", Danilo Nakamura, "Crescimento econômico e desintegração social: as raízes do mal-estar brasileiro reveladas nas 'jornadas de junho'" (em Marxismo21, 5 de jul. de 2013). Apenas uma boa amostra de que a ideia de insurgência começou a fazer o seu caminho pela metáfora original de um corpo que se levanta - e, segundo passo, quebra um feitiço, derrubando no caminho outro tabu, o da cabeça feita pela lavagem ideológica da mídia e congêneres na indústria cultural: as pessoas sabem que se trata de enganação mas mesmo assim agem como se não soubessem - em nada muda saber se a enganação é comercial ou oficial -, daí o enigma da força estranha que os arrancou do sofá, que as fez enfim se "insurgirem".

58. Na origem dessa boutade infeliz, encontra-se uma referência desajeitada e oculta à dimensão revolucionária do tédio, cujo fio Walter Benjamin principiou a desenrolar em Baudelaire e chegou até ao "situacionista" Raoul de Vaneigen, cujo Traité de savoir-vivre à l'usage des jeunes générations foi publicado exatamente um ano antes de Maio de 68. Para uma análise muito original daquela conjuntura centrada justamente no tédio que acompanha o processo de modernização de uma sociedade pacificada como a francesa - o último conflito nacional grave, a Guerra de Independência da Argélia terminara em 1962 -, e entendendo o tédio como um barômetro de época, um indicador do "tempo social que está fazendo", ver os dois primeiros capítulos do livro de Jean-Pierre Le Goff, Mai 68: L'Héritage Impossible (Paris: La Découverte, 1998). É quase certo que o mencionado palpite infeliz tenha tentado uma ligação direta, como se diz em futebol, com o artigo famoso de Pierre Viansson-Ponté, "La France s'ennuie" publicado no Le monde no dia 15 de mar. de... 1968. Menos de três meses depois, "a divina surpresa", redimindo o articulista e confirmando mais uma vez aquele afeto negativo no papel de agente provocador coletivo. Se o Brasil se entediava ou não para valer antes de Junho, no fundo é o que todos queremos saber, frivolidades à parte. Neste capítulo crucial dos sinais precursores da virada, sem propriamente entrar no assunto, o Diretor-responsável da revista Piauí elegeu o filme O som ao redor, do cine- segundo Sílvio Mieli. E segundo o argumento desenvolvido até aqui, se não surgiu obviamente do nada, veio finalmente preencher o vazio da doutrina contrainsurgente da Pacificação. O outro traço definidor desta verdadeira ruptura de época - não é lengalenga piedosa a convicção difundida de que depois de Junho o país nunca mais voltará a ser o mesmo - é que ao colocar-se de pé, a insurgência do corpo social caracterizou-se por "uma série de atos profanatórios" (grifo meu). Como profanação não é um a expressão qualquer, menos ainda de uso corrente no vocabulário político da esquerda - para não falar na prática, no zelo religioso com que a dita esquerda vem escrupulosamente ajoelhando e rezando, pouco importa se da boca para fora ou não, o que conta é o joelho dobrado - não penso estar avançando o sinal supondo que sua inspiração nesse passo - a compreensão da insurgência que levantou o país como uma profanação -, se apoia na recuperação política da ideia mesma de profanação sugerida por Giorgio Agamben ${ }^{59}$.

Nas suas escavações arqueológicas, Agamben notou a existência de uma relação muito especial entre "usar" e "profanar" como também redescobriu que o termo reli-

asta pernambucano Kleber Mendonça Filho lançado em janeiro deste outro ano que ainda não terminou, como muita gente anda dizendo, uma espécie de trilha sonora das revoltas de junho, sugerido mais no título da matéria editorial do que no corpo do texto, onde a trilha sonora é mesmo a vaia no estádio Mané Garrincha, na tarde de 15 de jun. (Fernando de Barros e Silva, "O som ao redor", Piauí, n. 82, jul. de 2013, p.7). Já que estamos recenseando, até uma ocorrência anódina alguma coisa assinala, onde se menciona a nova composição do establishment, "contra o qual as pessoas agora se insurgem". Por outro lado, é apenas um gesto trivialmente óbvio pedido pela cena, o de Clodoaldo e seu irmão, levantando-se da cadeira para o acerto de contas, que não poderemos dizer final, pois no plano seguinte o filme fecha com a explosão festiva do cachorro do vizinho, em efígie é claro.

59. Giorgio Agamben, Profanações (São Paulo: Boitempo, 2007). O original italiano é de 2005, tradução e apresentação de Selvino Assman. As citações e referências que se seguem encontram-se entre as páginas 65 e 79. 
gião não deriva de "religare", o que une o humano ao divino, mas de "relegere", que "indica a atitude de escrúpulo e atenção que deve caracterizar as relações com os deuses, a inquieta hesitação (o 'reler') perante as formas - e as fórmulas - que se devem observar a fim de respeitar a separação entre o sagrado e o profano”. Prolongo a citação para efeito de reconhecimento do terreno, que é familiar, como se pode perceber à primeira vista: "religio não é o que une homens e deuses, mas aquilo que cuida para que se mantenham distintos. Por isso, à religião não se opõem a incredulidade e a indiferença com relação ao divino, mas a 'negligência', uma atitude livre e 'distraída' - ou seja, desvinculada da religio das normas - diante das coisas e de seu uso, diante das formas da separação e de seu significado. Profanar significa abrir a possibilidade de uma forma especial de negligência que ignora a separação, ou melhor, faz dela um uso particular”. Só um olhar politicamente educado pelas verdadeiras profanações cometidas por Brecht - as tábuas consagradas do palco desviadas para o ringue de boxe, ou o praticável ruidoso e esfumaçado do cabaret, o público nem aí para os encantos do fosso e da quarta parede etc. para não mencionar toda a engrenagem de produção de atores "negligentes" na observação do ritual cênico mais do que milenar -, e, sobretudo Walter Benjamin, por ser nosso autor quem é, leitor contumaz do materialismo messiânico e antiprogressista de Benjamin: no caso, será suficiente mencionar a demolição da obra de arte aurática e correspondente apagamento da distância estética que congela os profanos na imobilidade contemplativa. E certamente pela incansável Crítica da Separação conduzida por Guy Debord e demais "situacionistas" até à beira de sua breve implosão em Maio de 68: na verdade, um continuum de separações, desde a mais espetacular, a do poder teológico-político e sua imagem soberana de onipotência, até à célula geradora de todas as hierarquias, o trabalho social separado de si mesmo na forma-mercadoria. Não, não estamos redescobrindo a pólvora, a crítica da religião desde Feuerbach como matriz da crítica materialista da ideologia e sua sequência política bem conhecida, da alienação-separação à reapropriação. É que o horizonte emancipatório encurtou de lá pra cá, não há mais nenhum tesouro expropriado a ser recuperado das entranhas em decomposição do capitalismo, levando autores idiossincráticos como Agamben a vasculhar no entulho arcaico da religião e do direito. Sim, o poder separador do sagrado subtraiu o essencial - coisas, lugares, animais, pessoas ao uso comum dos homens, e profaná-lo significa restituir ao livre uso o que antes estava indisponível, confiscado e preservado fora de alcance em sua aura.

Voltando aos destinos paralelos de há pouco: assim como era de se esperar que à época de seu surgimento a hipótese comunista fosse confrontada como se combate um sacrilégio, com exorcismo e fogueira, logo poderemos sugerir que seu eclipse contemporâneo algo tem a ver com as condições proibitivas que cercam a profanação-restituição, quer dizer, "a tarefa política da geração que vem"60. O outro elo da redescoberta da profanação para a ação política (direta, ou havia alguma dúvida?) diz respeito justamente à crescente incapacidade de profanar numa era de rituais a cuja letra já não corresponde mais nenhum espírito. Para isso é preciso lembrar que "a profanação não restaura simplesmente algo parecido com um uso natural, que preexistia à sua separação na esfera religiosa, econômica ou jurídica”. Abolir pura e simplesmente

60. Ver a respeito a apresentação esclarecedora de Selvino Assman. 
a forma da separação não basta para reencontrar um "uso não contaminado"61. Assim, se a propriedade também pode ser entendida como "o dispositivo que desloca o livre uso dos homens para uma esfera separada, na qual é convertido em direito", nem por isso a simetria da operação inversa da expropriação-reapropriação nos livra da praga do direito: não é uma evidência que "o uso antigo possa ser recuperado na íntegra, como se pudéssemos apagar impunemente o tempo durante o qual o objeto esteve retirado de seu uso comum"62. Por isso os franciscanos, em luta contra a Cúria romana no século XIII, insistiam na possibilidade de um uso totalmente desvinculada da esfera do direito, relembra Agamben, comentando numa entrevista: "o que está realmente em questão é, na verdade, a possibilidade de uma ação humana que se situe fora de toda relação com o direito, ação que não ponha, que não execute ou que não transgrida simplesmente o direito. Trata-se do que os franciscanos tinham em mente quando, em

61. A melhor ilustração ainda é a do jogo, cujos vínculos originários com o sagrado são bem conhecidos: "as crianças que brincam com qualquer bugiganga que lhes cai nas mãos, transformam em brinquedo também o que pertence à esfera da economia, da guerra, do direito e das outras atividades que estamos acostumados a considerar sérias. Um automóvel, uma arma de fogo, um contrato jurídico, transformam-se improvisadamente em brinquedos. É comum, tanto nesses casos como na profanação do sagrado, a passagem de uma religio, que já é percebida como falsa e opressora para a negligência como vera religio [...] trata-se de um uso cujo tipo Kafka devia ter em mente quando escreveu em $\mathrm{O}$ novo advogado, que o direito não mais aplicado mas apenas estudado, é a porta da justiça. Da mesma forma que a religio não mais observada, mas jogada, abre a porta para o uso, assim também as potências da economia, da política e do direito, desativadas em jogo, tornam-se as portas de uma nova felicidade" (Op. cit. p.67). Isso dito, somos lembrados de que o jogo como órgão da profanação está em decadência em todo lugar. Pior, como o demonstram os espetáculos esportivos de massa, ao secularizarem uma intenção inconscientemente religiosa, são consumidos como uma nova liturgia, de sorte que "fazer com que o jogo volte à sua vocação puramente profana é uma tarefa política", Ibidem, p.68.

62. No bom comentário de Selvio Assman, Op cit. p.10. sua luta contra a hierarquia eclesiástica, reivindicavam a possibilidade de um uso de coisas que nunca venha a ser direito, que nunca venha a ser propriedade. E talvez 'política' seja o nome dessa dimensão que se abre a partir de tal perspectiva, o nome do livre uso do mundo. Mas tal uso não é algo como uma condição natural originária que se trata de restaurar. Ela está mais perto de algo novo, algo que é resultado de um corpo a corpo com os dispositivos de poder que procuram subjetivar, no direito, as ações humanas"63.

Há, porém, uma pedra no caminho político da profanação, e graças a essa barreira a ser dinamitada, a intuição histórica de Sílvio Mieli, conjugando num só ato divinatório insurgência e profanação, pelo menos está livre do risco de virar receita. É que nesse meio tempo - na verdade, toda uma era -, continua o argumento de Agamben, a "religião capitalista alcançou a sua fase extrema". Ainda duas palavras, e voltamos aos atos profanatórios de Junho. Como se há de recordar, a tese benjaminiana de 1921 - poucas notas num fragmento póstumo -, segundo a qual o capitalismo é antes de tudo uma religião, voltou a circular, e Agamben justamente encontra-se entre seus novos leitores. ${ }^{64}$ Nas palavras originais do próprio Benjamin: “o capitalismo deve ser visto como uma religião, o capitalismo está essencialmente a serviço da resolução das mesmas preocupações, aflições, inquietações a que outrora as

63. Entrevista concedida à Folha de São Paulo, 18 de out. de 2005 citada por Selvino Assman, cit. p.11.

64. Entre nós, Michael Löwy consagrou-lhe uma conferência num colóquio promovido pela USP, há uns dois ou três anos, se não me engano, e acaba de organizar e apresentar pela Boitempo (São Paulo, 2013) uma coletânea de escritos pouco lidos de Walter Benjamin, a qual dá título o fragmento em questão $O$ capitalismo como religião. A tradução é de Nélio Schneider. 
assim chamadas religiões quiseram oferecer respostas.". Depois de contornar a concepção famosa de Max Weber o capitalismo não é mera secularização da fé protestante mas é, ele próprio, essencialmente um fenômeno religioso, como resume Agamben ${ }^{65}$-, Benjamin identifica três traços na estrutura religiosa do capitalismo: é uma religião puramente cultual; esse culto é permanente, para ele não existe "dias normais"; esse culto enfim, é um culto culpabilizador, não está voltado para a redenção ou para a expiação de uma culpa - um movimento monstruoso, em suma. ${ }^{66} \mathrm{O}$ ponto luminoso da visão benjaminiana encontra-se na primeira dimensão: uma religião, mas espectral, no sentido de que nele "todas as coisas só adquirem significado na relação imediata com o culto; ele não possui nenhuma dogmática, nenhuma teologia". Tudo se passa como se da secularização da ascese calvinista restasse apenas o osso do rito exclusivo, implacável e inegociável, um ritual cujo espírito se tornasse por fim a própria letra, e só letra. O capitalismo, estava dizendo Benjamin poucos anos antes do colapso de 29, enquanto tirava consequências da guerra química e observava a serpente chocar seu ovo, é no fundo um sistema de comandos absurdos ${ }^{67}$, e como tal necessitava, em princípio, de um espírito, como queria Weber, que justificasse aos olhos de suas vítimas

65. Idem, Ibidem, p.70.

66. Walter Benjamin, o capitalismo como religião, cit. pp.21-2.

67.“Tudo bem pesado, o capitalismo é um sistema absurdo: nele, os assalariados perderam a propriedade do resultado do seu trabalho, e a possibilidade de manter uma vida ativa fora da subordinação. Quanto aos capitalistas, eles se encontram acorrentados a um processo sem fim e insaciável, totalmente abstrato e dissociado da satisfação das necessidades de consumo, sejam elas até mesmo necessidade de luxo. Para esses dois tipos de protagonista, a inserção no processo capitalista carece singularmente de justificações”, Luc Boltanski e Ève Chiapello. Ibidem, p.41. e supostos beneficiários - obrigados igualmente a dizer amem para salvar a alma - tamanha mobilização de corações e mentes, só que no ponto de saturação a que chegara, coincidindo afinal sem deixar resto, com a formalidade cega de seus imperativos de nascença, "o cumprimento preciso da ordem tornara-se mais importante que o conteúdo das ordens", como foi dito pouco depois acerca desse mesmo ritualismo puramente cultual.

O cumprimento preciso da ordem tornara-se mais importante que o conteúdo das ordens: dito, ou escrito, em algum momento entre meados dos anos 30 do século passado e 1946, por Günther Anders, quando afinal publicou seu extraordinário livro sobre um autor ainda muito mal lido e ainda menos compreendido, Kafka. (Estou citando na nova tradução de Modesto Carone, a primeira é de 1969, publicada em 2007 pela CosacNaify ${ }^{68}$.) Pois bem, para Günther Anders, Kafka foi o porta-voz literário de um "ritualismo sem ritual", entendendo por ritual o que estamos chamando aqui, na esteira do fragmento de Benjamin relido por Giorgio Agamben, o “espírito” ausente de uma religião cujo único significado se refere ao cumprimento de um culto. Não estaremos forçando a mão, muito pelo contrário, voltando à nota original, se dissermos que o mundo de Kafka na chave identificada por Günther Anders, um mundo regido por um imperativo categórico monstruoso, "cumpra com precisão os deveres que não conhece!" é exatamente o mundo no qual seu leitor e contemporâneo Walter Benjamin reconheceu o capitalismo como uma religião puramente ritualística, empurrando, por sua vez, para o primeiro plano justamente aquele motivo originário da religião, a precisão, o escrúpulo, o ritu-

68. Kafka: pró e contra. p.105. 
alismo, tal como Kafka possivelmente lhe ensinara a ver e Günther Anders por seu turno nos ensinou, e caso tivesse porventura tomado conhecimento do fragmento benjaminiano sem dúvida concluiria: pois não é que nos deparamos com a mesma combinação de um quadro agnóstico e processos ritualísticos tanto no universo de Kafka como no capitalismo cultual de Benjamin? Deu-se então a junção demoníaca das duas esferas fantasmagóricas. À pergunta: onde houve agnosticismo ligado a escrúpulos e a ritualismo? Günther Anders deu uma resposta: "sob o terror fascista no qual pessoa nenhuma sabe o quê em dado momento é exigido dela, porque alguma coisa nos é exigida - mas onde se espera dela o cumprimento mais escrupuloso do indevassável ou do desconhecido"69. Conhecemos a resposta de Agamben: na religião capitalista em sua fase contemporânea extrema. Assim, a prática negativa que inspira todo ato profanatório hoje remete, nada mais nada menos, àquele horror que revestira o capitalismo com a "aparência de uma religião compacta e encouraçada”. Mesma resposta para a pergunta: onde é válido o abominável imperativo categórico estilizado por Kafka? Num mundo onde "só se permite auto humilhação e desespero". Foi assim, continua Günther Anders, naquele "estado terrível em que ninguém se achava digno de saber, mas era obrigado a agir com exatidão"70. E continua assim graças a este novo e tremendo dispositivo da religião capitalista que estamos chamando de Neoliberalismo. A prova? Basta uma, de tão bem produzida e inapelável. Estudando um objeto desprezível e soterrado

69. Ibidem, p.105.

70. Ibidem, p.106. sob montanhas de lugares comuns bem pensantes acerca da mídia e da natureza humana, a epidemia dos reality shows, e nada sabendo do fragmento benjaminiano acerca do capitalismo como processo religioso culpabilizador meramente ritualístico, e muito menos tendo notícia de que Agamben baseara seu elogio da profanação anticapitalista naquela visão do capitalismo como um sistema de deveres a serem tanto mais religiosamente cumpridos quanto mais indevassáveis fossem seu desígnios - a socióloga Silvia Viana, a cujo livro estamos de volta, não só refez por conta própria toda essa tradição crítica, como acrescentou uma nova dimensão ao argumento, a agonia do trabalho descartável, mostrando que o capitalismo como religião em sua forma contemporânea tornou-se um espantoso e interminável "ritual de sofrimento". ${ }^{71}$ Não será possível acompanhar todos os passos da autora a caminho de sua descoberta, a saber, que os rituais absurdos, escrupulosamente observados pelos voluntários que dele participam por contrato, como se fosse a coisa mais natural do mundo, embora todos saibam que não é nada disso, o espetáculo colorido do consumo, por exemplo, são na verdade "rituais de sofrimento", mas de um sofrimento muito particular, o que se padece no inferno do mundo do trabalho contemporâneo. Em tempo: "mundo do trabalho" é a rigor mera força de expressão, além do mais consagrada pela literatura especializada, cuja anatomia, como a presente e um bom número de reconstituições similares, é a prova cabal e paradoxal de que o trabalho, tal como o conhecíamos, perdeu sua capacidade de formar um "mundo", e como tantos outros "mundos", o do trabalho também chegou ao fim e com ele uma nova pergunta está

71. Silvia Viana, Rituais de sofrimento (cit.). 
abrindo caminho: o que significa trabalhar depois do fim do mundo? O que atrai o nosso olhar não é algo obsceno, mas o fundamento mesmo da nossa reprodução social, a vida produtiva organizada na forma de empresas flexíveis que gerem sua força de trabalho segundo uma lei ditada por um deus oculto, a da eliminação, sob a aparência arbitrária de um jogo cuja finalidade não é selecionar um vencedor mas condenar todos os demais ao "paredão". Tem mais nesse achado: não se trata de uma melodramática imitação da vida, como aliás já vimos em um passo anterior deste ensaio, os programas funcionam gerenciando (flexivelmente) a força de trabalho à sua disposição segundo os mesmos rituais em vigor na vida real das empresas cujas vagas são a razão de ser do 'pega pra capar' em cena. As provas são rituais com requintes caprichados de aflição, além do mais, porque se trata de "vencer uma competição na qual as regras mudam ao sabor do vento", mas não à toa, mas para que, no final, "fiquem apenas o sentimento do mero acaso e o agradecimento à Providência pelo saldo positivo na roleta russa da vida", no comentário de Isleide Fontenelle, resenhando o livro $^{72}$, que ainda se pergunta: que forma de vida resulta de uma organização social guiada pela lógica da eliminação? Por certo uma forma social, responde, em que o estado de alerta precisa ser permanente. Uma vida, no mínimo autopoliciada, cujo complemento de segurança sabemos bem qual seja. $O$ que a visão do capitalismo como religião, na sua última configuração como ritual de sofrimento, está mostrando nos reality shows, por sua vez laboratórios de iniciação à nova razão do mundo, "são processos seletivos marcados por uma seleção negativa, ou seja, as pessoas vão sendo

72. "Vida, o reality show", RAE/GV, Vol.53 n. 3, maio-jun. 2013. eliminadas não porque não são boas o suficiente mas porque há uma cota de eliminação que precisa ser respeitada. A eliminação é, portanto, o meio e o fim" "73. Não sei qual anjo da guarda dos sociólogos colocou Silvia Viana na pista luminosa de Kafka e Primo Levi, entre tantos outros autores essenciais para se captar, na etapa contemporânea do capitalismo-religião como dispositivo de controle por eliminação, a chave que permite abrir seu momento fundacional, a irrupção fascista de entre guerras. O essencial para a administração dos campos, dizia Primo Levi, "não é que sejam eliminados os mais inúteis e sim que surjam logo vagas em uma porcentagem prefixada". É só conferir a atualidade-digamos "neoliberal" e não capitalismo desregulado, fora da coleira, como pensam os que imaginam o capitalismo como um parque temático das forças produtivas - das observações de Hannah Arendt, que nossa autora, arregalando bem os olhos, simplesmente viu na telinha: a organização do inferno funcionava à perfeição não a despeito mas porque não carecia da menor explicação, mesmo a mais esdrúxula; naquele mundo indecifrável, os mais insensatos e infindáveis cerimoniais, eram de fato a "ideologia nazista", que não existia na primitiva nulidade de seus dogmas - afinal o quadro era agnóstico, como lembrado por Günther Anders - mas em seus rituais, cujo principal era o da seleção. (Será preciso evocar a ciranda macabra, e minuciosamente protocolada, das cerimônias de eliminação em Saló, de Pasolini?). Convenhamos que parece não haver ainda milagre dialético disponível que desentranhe alguma etapa superior do que quer que seja desse último círculo da religião capitalista: um século de guerra social pode ter mostrado que nenhum

73. Isleide Fontenele, Ibidem. 
futuro será parido por esse círculo infernal, nenhuma gestação imanente movida a quantas negações da negação se queira. A tarefa da nova geração agora é outra: como se livrar desse sistema de normas, práticas, dispositivos, de todo esse cerimonial de acumulação, de sofrimento alimentado por seus próprios adoradores? Numa palavra, como sair? Não há resposta, muito menos no ensaio de Silvia Viana, salvo um gesto luminoso e único que irrompe nas últimas linhas do último capítulo. Quando se vê um participante de um Big Brother sendo levado a um dos tais quartos de intensificação máxima do processo seletivo nos conta a autora - dá para adivinhar o que o programa está sussurrando no ouvido do concorrente, àquela altura já nas últimas: "pede para sair, vai, pede para sair...”. Às vezes acontece de pedir mesmo, mas é raro, já que a Lei da empresa-reality show, tanto quanto a empresa da realidade que dispensa o show, proíbe recusar o sofrimento gratuito, "pois a violência vã não é apenas autoreferida, é autopropulsionada, trata-se de uma violência impotente, pois põe em movimento o mundo para que não se mova"74 Desistir sem tentar é assim pecado mortal. De passagem, nossa autora sugere que o bordão do filme Tropa de elite só se tornou a epidemia que se sabe por escarnecer, ainda por cima numa voz de comando que aconselha, dos milhões de mobilizados pela disciplina do trabalho, em cujo mundo de resto não há mais vagas para todos. Por isso a ordem é pedir para sair. E quando pedem também pedem desculpa por terem sucumbido ao desespero do momento - e os que vão até o fim e são eliminados, são premiados com a "estranha legitimidade de quem agiu de acordo com a Lei”. Até que o milagre aconteceu. "Uma

74. Silvia Viana, Ibidem, p.169. participante não pediu para sair, nem foi eliminada. Ela simplesmente saiu. Não fez discursos, não brigou, não exigiu nem acusou. Fez suas malas e saiu". Obviamente foi execrada por todos. Com a autora, a última palavra, abrindo os trabalhos da geração que vem: "não aceitar as porradas da vida? Profanação" (grifo meu) ${ }^{75}$.

Como lembrado acima, a crítica materialista da alienação-separação, cujas metamorfoses culminam na sociedade burguesa, principiou historicamente pela crítica da religião como instituição do sagrado enquanto dispositivo ou poder que subtrai e confisca coisas, lugares, animais e pessoas, da livre circulação entre os homens. E que portanto, deste ângulo, toda crítica é um ato profanatório - o que Debord chamava de prática negativa. Ora, a conclusão de Agamben é que o capitalismo contemporâneo enquanto religião total, quer dizer, um ritualismo integral, impulsionado por imperativos meramente cultuais, tornou-se um sistema inteiramente voltado para a "criação de algo absolutamente Improfanável” - e assim sendo, a profanação do improfanável tornou-se a tarefa política da geração que vem. E se estamos no bom caminho, é essa a mesma tarefa da insurgência que vem, devidamente esconjurada pela Marcha dos Pacificadores, iniciada faz algum tempo à procura do seu verdadeiro alvo: a prova de que finalmente o encontraram é que também desceram em massa para as ruas de Junho. E mais: dependendo para onde se desloque o establishment e sua composição, impossível não se dar conta de que os Coxinhas também se insurgiram. Na mesma medida desse deslocamento, também variam as cores dos Contra. Do branco ao vermelho antigo, são mais de quarenta os tons do consenso maca-

75. Idem Ibidem, p.161. 
bro em expansão, o consenso da Paz e da Oportunidade, ao qual voltaremos, embora dele nunca tenhamos saído.

Interessará saber por certo que mais adiante Agamben enfrentaria esse nó que torna particularmente problemáticos os atos profanatórios aos quais confiamos a tarefa de libertar o que foi capturado e separado por meio dos dispositivos e restituí-los a um possível uso comum. É que "os dispositivos com os quais temos que lidar na atual fase do capitalismo não agem mais tanto pela produção de um sujeito quanto por meio de processos que podemos chamar de dessubjetivação”. Contra eles, a profanação que restitui ao uso comum o que a separação capitalista havia sacrificado parece que não funciona mais, ou pelo menos não mais como nos tempos da prática negativa que costumávamos chamar de política. ${ }^{76} \mathrm{Um}$ breve apanhado talvez ajuda a reconhecer nos atos de Junho o que eles realmente foram: profanações cometidas por gente sem nome que nem está pedindo para sair nem aceitando as porradas da vida. Nem aceitando a cosmologia difundida pelo BOPE nas empresas, repartindo o mundo entre "caveiras" e "invertebrados"77. Pois voltemos à não menos curiosa cosmologia de Agamben. Nela o universo também é composto por duas grandes classes de existentes: de um lado, os seres viventes, de outro os tais dispositivos, em cujo âmbito os primeiros são incessantemente aprisionados, desde sempre no sentido da primeira teologia da Pro-

76. Giorgio Agamben, “O que é um dispositivo?", incluído na coletânea O que é o contemporâneo? (Chapecó: Argos, 2009), p.47. Tradução Vinicios Honesko.

77. Conforme relato de palestra motivacional para empresas ministrada por um oficial do BOPE, analisada no livro de Silvia Viana Rituais de sofrimento, p.162. A propósito: na telinha dividida entre manifestantes pacíficos e vândalos baderneiros, como discriminar em cada um dos campos caveiras e invertebrados? vidência Divina governando o mundo, isto é, dispositivos que enredam os viventes na intenção de melhor governá-los e guiá-los para o bem. Ampliando bastante a classe dos dispositivos inventariados por Foucault, Agamben dará tal nome "a qualquer coisa que tenha de algum modo a capacidade de capturar, orientar, determinar, interceptar, modelar, controlar e assegurar os gestos, as condutas, as opiniões, e os discursos dos seres viventes. Não somente, portanto, os manicômios, o Panóptico, a escola, a confissão, a fábrica, as disciplinas, as medidas jurídicas etc., cuja conexão com o poder é num certo sentido evidente, mas também a caneta, a escritura, a literatura, a filosofia, a agricultura, o cigarro, a navegação, os computadores, os telefones celulares etc."78 Como a lista poderia se expandir até os confins do mundo conhecido, poderíamos acrescentar alguns itens de Junho, como UPPs, catracas, megaeventos, redes sociais, armamentos humanitários, máscaras, e muitos eteceteras que ainda não deram o ar de sua graça, além de outros velhos conhecidos, como os Institutos de Pesquisa, os talk shows, as Políticas Públicas de sempre, redesenhadas para atender às novas demandas identificadas pelos Data Isso e Aquilo, Pronto Atendimento Jurídico, faixas exclusivas de ônibus, Mais Médicos, Regimes Semiabertos fechados e vice-versa etc. Entre os seres viventes e os dispositivos, Agamben fecha sua cosmologia com um terceiro grupo, os sujeitos. Tudo aquilo que resulta da relação corpo a corpo entre os viventes e os dispositivos. São as subjetivações estudadas por Foucault, por exemplo: a constituição de um sujeito delinquente e de um milieu delinquente produzido pelo dispositivo prisional, que por sua vez se torna sujeito de novas

78. Idem Ibidem, pp.40-41. 
técnicas de governo; ou a formação da subjetividade ocidental por excelência, "ao mesmo tempo cindida e, no entanto, dona e segura de si”, inseparável da ação plurissecular do dispositivo penitencial inaugurado pela prática da confissão. Este o caso privilegiado por Agamben, pois lhe interessa destacar o eclipse contemporâneo deste processo de subjetivação por excelência, o processo da cisão provocada pelo dispositivo penitencial, "produtora de um novo sujeito que encontrava a própria verdade na não-verdade do Eu pecador repudiado". Se um dispositivo não desencadear um processo de subjetivação, não poderá funcionar como um dispositivo de governo, reduzindo-se então a um mero exercício de violência. (Foi pensando em particularidades como estas que Lívia e Dafne incluíram as UPPs no rol dos dispositivos de gestão de uma ampla faixa da população carioca). Para efeito de contraste de época, uma recapitulação: "Numa sociedade disciplinar, os dispositivos visam, através de uma série de práticas e de discursos, de saberes e de exercícios, a criação de corpos dóceis, mas livres, que assumiam a sua identidade e a sua 'liberdade' de sujeitos no próprio processo de assujeitamento. Isto é, o dispositivo é, antes de tudo, uma máquina que produz subjetivações e somente enquanto tal é também uma máquina de governo.”79 Já não é mais assim com a espantosa acumulação e proliferação de dispositivos que vem a ser o capitalismo de controles rituais sob o qual vivemos, pois na operação de tais dispositivos o momento dessubjetivador tornou-se a tal ponto preponderante que parece não haver mais lugar para a recomposição de novos sujeitos, como no período estudado por Foucault. Havia na raiz de todo dispositivo "um desejo demasiadamente humano de feli-

79. Idem Ibidem, p.46. cidade, e a captura e subjetivação deste desejo, numa esfera separada constituíam a potência específica do dispositivo." Por isso a profanação poderia operar como um contra-dispositivo, e operar justamente pelo, digamos assim, titular de uma subjetivação conflituosa em vias de se consumar. Horizonte perdido nas sociedades contemporâneas, atravessadas por gigantescos processos de dessubjetivação, mas não por isso, que é o caminho da modernização, para recorrer a outro repertório, mas precisamente porque a tais processos não correspondem mais nenhuma subjetivação real. A política de classes girava em torno dessas subjetivações, política cujo antagonismo constitutivo estruturou todo um campo de "instituições", para voltar a falar à moda antiga. Com o seu eclipse, por falta de sujeitos e identidades reais, a "economia" triunfa sem inimigos como pura atividade de governo que visa apenas a sua própria reprodução. E governo do mais dócil e frágil corpo social jamais constituído na história da humanidade. Teríamos então tocado o fundo distópico de toda essa engrenagem, o limite do ato profanatório. Chegamos, ao que parece, ao indivíduo absolutamente governável, “o inócuo cidadão das democracias pós-industriais, que executa prontamente tudo o que lhe é dito e deixa que os seus gestos cotidianos, como sua saúde, os seus divertimentos, como as suas ocupações, a sua alimentação e como os seus desejos sejam comandados e controlados por dispositivosaté nos mínimosdetalhes". ${ }^{80}$ Aqui o nó górdio. O coletivo invisível que animava a controvertida revista Tiqqun batizou esse personagem cuja "vida besta" transcorre "pastando mansamente entre serviços

80. Idem Ibidem, p.49. 
e mercadorias"81, com um nome próprio pescado na figura central do Ulysses de Joyce, merecendo de quebra toda uma teoria, a Teoria do Bloom ${ }^{82}$. Uma outra caracterização mais recente na construção desse herói do nosso tempo, depois de lembrar que vive um Bloom em cada um de nós, descreve-o como alguém que "destrói laboriosamente suas possibilidades de vida na mobilização infinita de uma atividade que ele sabe, entretanto, ser incapaz de jamais produzir uma 'ação' digna desse nome. O Bloom é colocado [pelo coletivo Tiqqun] como a figura emblemática desse ‘empreendedor de si mesmo' que cultua e dispende assiduamente um 'capital humano' com o qual ele não sabe o que fazer"83. Ocorre, continua a Teoria, que nesse Bloom nosso de todos os dias vive adormecido um "terrorista" virtual, como se vê mundo afora na monótona recorrência dos massacres à maneira de Columbine e assemelhados. Agamben adota a hipótese - nada se assemelha melhor ao terrorista do que o homem comum -, acrescentando, porém, que esta hipótese do despertar terrorista das células Bloom adormecidas nos seres acometidos pelos processos de dessubjetivação, se origina e inspira a grande estratégia do Estado de Segurança Preventiva, cujo permanente estado de alerta conta com a colaboração autovigilante desses mobilizados da imobilidade. Como as conjunturas mentais variam, é bom lembrar que esse fantasma do pai de família que à noite se transforma num hooligan incendiário, passou a assom-

81. Como o descreve, por sua vez, Peter Pál Pelbart, O avesso do niilismo: cartografias do esgotamento (São Paulo: N-1 Edições, 2013, p.29).

82. Théorie du Bloom (Paris: La Fabrique, 2000).

83. Yves Citron, "Une réaction symptomatique", Multitudes no35, Paris, janeiro de 2009, citado por Peter Pál, Ibidem. brar a tradição crítica radical em estado de choque com a guerra civil mundial que seguiu de perto a desintegração da paz armada propiciada pela Guerra Fria. Se a qualquer momento um vagão de metrô poderia tornar-se uma Bósnia em miniatura, tudo indicava que o processo civilizador descrito por Norbert Elias, responsável pela progressiva pacificação das sociedades, estava dando para trás. Como estava dando para trás o improvável sentido do terror político nos anos de chumbo na Itália e na Alemanha, na brasa dormida de quase duas décadas da herança impossível de 68. Nas suas visões da nova guerra civil, Hans Magnus Enzensberger foi dos primeiros a entrever, e obviamente temer, "o vazio no centro do terror" que desde então descreveu, justamente, como um "terror sem ritual"84. Já vimos como ritualismo sem ritual é conosco mesmo, estamos apenas interpolando uma outra data na escalada. As elucubrações de Agamben em torno da hipótese Bloom - segundo consta, inspiradas por ele mesmo -, acerca das consequências explosivas da dessubjetivação endêmica causada pela proliferação dos novos dispositivos de governo, são anteriores à grande crise de setembro de 2008 -alguém se lembra? Certamente não mais, pois o estado de emergência econômica permanente no qual nos encontramos faz tempo tornou-se modo de vida. Deu-se então o que ninguém esperava. Conforme apertava o garrote da austeridade, as células Bloom adormecidas despertaram, mas despertaram menos terroristas e mais "indignadas", de preferência conectadas em rede. No Brasil, foi o Grande Despertar Coxinha. Todos pela Paz que veio preencher o vazio no centro do terror.

84. Num artigo de 1991 citado e comentado por Robert Kurz no Colapso da modernização (São Paulo: Paz e Terra, sexta edição revista, 2004, p.189). 
Voltando então aos sinais que anunciavam os contradispositivos profanatórios, que por seu turno abririam caminho para o "comum", é bom ter em mente um aviso histórico aos navegantes: no Brasil, ingovernável mesmo só índio, sobre o qual o neodesenvolvimentismo de agora está passando o rodo da solução final. Para eles também, depois de Junho a paz será total.

\section{5.}

MPL insurgente? Tem lá sua graça. Podendo parecer, inclusive, descabida, pois é praxe consolidada na literatura do movimento tratar os episódios maiores da luta pelo transporte coletivo livre como revoltas populares. Não começou em Salvador (2003) nem vai terminar em São Paulo (2013)? Certamente. Como também não é menos cer to de que algo de novo surgiu em Salvador com a Revolta do Buzú. Pela primeira vez, o que era para ser mais uma manifestação estudantil, virou ensaio geral de uma revolta popular, na avaliação de Manolo. Nas suas palavras, "um evento de dimensões jamais imaginadas por quem quer que fosse"85. Mas não custa testar, à luz do presente exercício de imaginação política: ligar os pontos e reconhecer os sinais dentro da figura, nada mais, nada menos.

85. “Teses sobre a revolta do Buzú”, disponível no Passa Palavra. Uma transformação análoga pode ter acontecido em junho de 2013 no que concerne a natureza da revolta popular deflagrada de novo pela questão específica do transporte. Neste sentido, não me parece inócua a variação no repertório que estamos tentando identificar desde o início.
Pois então, por falar em imaginação, se há alguma coisa que mexe, e bem lá no fundo, com a imaginação social e política das pessoas é a circulação nas cidades.

Ao começar a se organizar em plano nacional, logo após sua mais do que improvável vitória em Florianópolis em junho de 2004, derrubando o aumento das tarifas de ônibus, depois de ocupar por semanas as principais vias da cidade, nelas incluídas as duas pontes que ligam a metade insular da capital à sua extensão continental - vamos lá: profanação de um santuário estratégico -, o futuro MPL deve ter sentido que afinal tocara nalguma mola secreta ancestral, a ponto de arriscar uma profecia: "todos demos o sangue pela vitória desta atividade [sic] pois ela vai desencadear um processo de revoltas simultâneas jamais visto no Brasil"86. Dito e feito. Mesmo assim, o espanto não foi menor. ${ }^{87}$ Nas palavras de um veterano da luta pela tarifa zero, não seria preciso quebrar muito a cabeça para desconfiar que a questão do transporte coletivo deve encerrar uma memória específica de anseios históricos tão fortes, que ao menor solavanco vira uma revolta popular. ${ }^{88}$ Como se um sentimento atávico de insurgência

86. Elena Judensnaider, Luciana Lima, Pablo Ortellado, Marcelo Pomar, Vinte centavos: a luta contra o aumento (São Paulo: Veneta, 2013).

87. Deixando mais uma vez a esquerda perplexa e a direita, indignada. "A força e as proporções assumidas pela luta contra o aumento das tarifas em São Paulo e outras capitais surpreenderam quase toda esquerda organizada. Um mês antes, dificilmente se previa que uma mobilização de rua fosse alterar de tal modo a conjuntura e impor uma derrota ao governo estadual e à Prefeitura, logo às vésperas da Copa das Confederações. Nossa dificuldade de compreender e responder a esse processo pode nos ajudar a explicar o preocupante avanço conservador no interior da mobilização". Caio Martins Ferreira, "O povo nos acordou? A perplexidade da esquerda diante das revoltas", Passa Palavra, 22 de jun. de 2013. Voltaremos a este ponto cego.

88. Ver entrevista de Lucas de Oliveira a Maria Carlotto, 28 de jun. de 2013, Fevereiro. 
fosse reativado no calor de um confronto cujas raízes se perdem, não na noite dos tempos, mas nos primórdios da urbanização capitalista.

Na greve geral que paralisou e amotinou a cidade de São Paulo em julho de 1917, no repertorio variado da revolta, sem que houvesse encomenda ou precedente conhecido, lá pelas tantas, vários bondes foram sequestrados, os cobradores cruzaram os braços e os motorneiros deixando-se levar pelos passageiros rebelados, porém em férias, embaralhavam as linhas, conforme lhes ditava a fantasia daqueles viajantes de ocasião. Num cenário clássico de jornada insurrecional - tropas nas ruas, armazéns saqueados, autoridades sitiadas -, tudo se passa, na observação de alguns historiadores, como se o "espírito de carnaval" tivesse baixado na massa proletária em movimento, disposta a tomar ao pé da letra a ocasião única em que a sociedade estava saindo dos trilhos. ${ }^{89}$ Aquele detournement dos bondes, na acepção "situacionista" do termo, seria mesmo um flagrante do mundo de ponta-cabeça, separações e hierarquias se quebrando, mas sobretudo confirmando a presença de um apelo original de ultrapassagem, algo como a transcendência de uma finalidade sem fim alojada num simples meio de transporte, num aparato técnico de indivíduos-pagantes num meio urbano reordenado pela produção de mercadorias.

89. "O chamado 'espírito de carnaval' - expressão lúdica de uma breve liberação dos rígidos quadros da existência cotidiana - aparece em alguns momentos. Após narrar a invasão dos bondes pela massa de garotos que marcam passagens, que forçam os motorneiros a levá-los para onde querem, observa o circunspecto O Estado de São Paulo: “o mais deplorável, é que um bando de mocinhas, infelizes operárias de fábricas, imitou o gesto da garotada, tomando conta de três elétricos no largo da Sé". Boris Fausto, "Conflito social na República Oligárquica: a greve de 1917”, Estudos CEBRAP, n 10 , São Paulo: 1974, pp.88-9. Ver ainda Antonio Mendes Junior e Ricardo Maranhão, Brasil história, volume 3: República Velha (São Paulo: Brasiliense, 1979, pp.319-20).
Em seu sentido figurado, o substantivo "transporte" também significa arrebatamento, sensação de entusiasmo e êxtase, no qual se apoia Paul Virilio para avançar o sinal - como de hábito - e concluir, da existência, ao longo de toda história, de uma "errância revolucionária não expressa, não revelada”, a organização de um Primeiro Transporte Coletivo, que vem a ser a própria Revolução ${ }^{\mathbf{9 0}}$. Demasia retórica? Talvez até seja, mas tomamos ultimamente um tal porre de Direito à Cidade, que por vezes esquecemos de alguns nexos fundamentais como a presença paradoxal da circulação em todas as revoluções, evidente, por exemplo, na persistência fossilizada na memória coletiva, de alguns comandos antitéticos como o "proibido estacionar" e o automatismo policial diante de qualquer ajuntamento, "circulando, circulando"91.

90. Paul Virilio, Velocidade e política (São Paulo: Estação Liberdade, Prefácio Laymert Garcia, tradução Celso Paciornik, 1996, p.21).

91. Interessado nos vínculos entre velocidade e política - e com um olho no desfecho sinistro do seu primeiro capitulo na crise da sociedade liberal-burguesa de entre-guerras, resumido na frase de Goebels em 1931, palavra de ordem durante a batalha entre fascistas e militantes socialistas e comunistas pela conquista de Berlim: “quem conquistar a rua, conquistará também o Estado!", de sorte que o ponto cego compartilhado pelos dois campos inimigos consistia simplesmente na capacidade de "colocar em marcha", "mobilizar" como se põe em movimento um exército, no caso uma massa proletária rachada de alto a baixo e deslocada dos locais de produção para a rua, tanto pela força do desemprego quanto pela das organizações de classe, onde então se realizava a mutação decisiva, a configuração revolucionária, mas também contrarevolucionária se nos voltarmos para o lado oposto, operada no momento em que o substituto técnico da máquina torna-se ele próprio motor, máquina de assalto, isto é, "produtor de velocidade", e essa corrida, é bom não esquecer, por se tratar de um movimento da lógica da corrida, os fascistas ganharam -, interessado portanto nos vínculos entre velocidade e política, Virilio está nos remetendo a uma era geológica da qual não se tem mais memória, muito embora seus vestígios ainda sejam perceptíveis na guerra de hoje entre Trânsito e Mobilidade, não sendo menor o risco dos contendores compartilharem a mesma lógica da aceleração, mesmo quando os ativistas de hoje se dão ao luxo da vida em câmara lenta, com ou sem bicicleta. Dois ou três exemplos não serão demais, sobretudo se observarmos que a visão idiossincrática do Virilio de 40 anos atrás está deixando cada vez mais de ser uma anomalia, pois para ele o poder burguês sempre foi militar antes de ser econômico. Por outro lado, 
Essas afinidades eletivas entre Comuna Revolucionária e Transporte Coletivo transparecem novamente nos poucos dias de novembro de 1935 durante os quais a cidade de Natal esteve em poder dos sublevados, organizados numa junta governativa composta de um sargento, um sapateiro e dois funcionários públicos, sendo um deles trabalhador dos correios: entre outras providências expropriadoras imediatas, o transporte municipal passou para as mãos dos seus usuários, a rigor toda a população numa cidade de raros carros particulares, e ao que parece por iniciativa dos estudantes. Se o ar que se respira dentro da cidade deveria ser o da liberdade (deixando obviamente entre parênteses suas origens militares e atual destino de fortaleza urbana), então não seria descabido afirmar, na esteira dessas duas amostras nada triviais, que ao circular livremente por ela sentimos soprar na

sendo arquiteto de profissão, Virilio não acredita em urbanismo. A seu ver a cidade é apenas uma paragem, uma plataforma de vigilância, "onde se associam instrumentalmente o olhar e a velocidade de locomoção dos veículos". No fundo o que existe é apenas "circulação habitável" (Ibidem, pp.19, 20 e 21.). Um vestígio eloquente, tanto num vilarejo francês quanto na distópica Los Angeles: "ao que parece, esqueceu-se que a rua é tão somente uma estrada atravessando uma aglomeração urbana, ainda que, a cada dia, entretanto, a legislação sobre a 'limitação de velocidade' dos veículos na cidade nos evoque essa continuidade do deslocamento" (Ibidem, p.21). Outra heresia: apenas secundariamente o poder político do Estado é o poder organizado de uma classe para a opressão de outra. Num plano mais material, ele é sobretudo um poder de polícia num sentido muito peculiar: "serviço de manutenção do sistema viário", por isso, continua, desde a aurora da revolução burguesa o poder político sempre associou "a ordem social com o controle da circulação - das pessoas, das mercadorias - e a revolução, o levante, com o engarrafamento, o estacionamento ilícito, o engavetamento, a colisão" (Ibidem, p.28). Último aviso aos navegantes: "desde a tomada do poder, o governo nazista ofereceu ao proletariado alemão esportes e transportes [grifo meu]. Acabam-se as revoltas, não há necessidade de muita repressão; basta esvaziar a rua prometendo a todos a estrada: é o objetivo político do Volkswagen, verdadeiro plebiscito já que Hitler convenceu 170.000 cidadãos a adquiri-lo apesar de não haver um único disponível (Ibidem, p.37). 
nuca um vento forte de utopia ${ }^{92}$, a qual, sem tirar nem pôr, o MPL, vitorioso nas ruas de São Paulo ${ }^{93}$, demons-

92. Espero não abusar dos bons argumentos de Daniel Guimarães Tertschitsch ("Deslocamento é lugar”, Urbânia, nº4, Editora Pressa, 2010), se estender até eles essa reminiscência apenas sugerida de vento utópico que parece soprar em todas as revoltas populares, e mais especialmente, é claro, naquelas cujo detonador envolve o pesadelo do transporte como um mau sonho encobridor de uma secreta convocação para outras viagens. A verdade para a qual Daniel chamou atenção, ao rediscutir em nova chave a questão da mobilidade urbana, teria a ver com a equivalência em importância entre o "caminho" e o "destino", de tal modo que "ir para um lugar já é, objetivamente, um lugar em si". Como para a imensa maioria da população da cidade, a vida gira em torno de dois eixos, um diurno, o trabalho, outro noturno, a formação para o trabalho, numa palavra, apenas ir e voltar dos locais do trabalho e do estudo, "o deslocamento já é trabalho" e por isso mesmo um lugar em que de algum modo já principiou o uso, ou abuso, de um tempo gasto e não pago e assim sendo quem deveria arcar com os custos com o deslocamento para o trabalho seria o empregador. Na entrevista mencionada há pouco, Lucas de Oliveira observa que com a aprovação em 1985 da lei do vale transporte, os quebra-quebras a bem dizer pararam, retornando apenas em 2003. Mas o argumento em favor da tarifa zero e do controle público sobre o sistema de transporte não para por aí, visa mais alto: "por que encarar como legítimos apenas os deslocamentos para as funções “oficiais" da cidade (trabalho e formação)?”. A dúvida é mais funda do que parece. Os insurretos de 1917 em São Paulo também fizeram a experiência do deslocamento como lugar, subvertendo-lhe porém o sentido ao romperem o recorte de classe daquelas funções oficiais. Para os moleques de rua - talvez os mesmos que faziam tiro ao alvo nos postes de iluminação, facilitando a movimentação noturna dos trabalhadores amotinados, mudar a seu bel prazer, embaralhando-as, as linhas dos bondes, podia ser, e de fato era, apenas um jogo, mas como vimos, nele também acontece a passagem que está nos interessando do sagrado ao profano, no caso, mais uma vez, pelo uso incongruente com o "oficial" de um dispositivo que não por acaso até hoje atende pelo nome popular de “condução". É pouco? Sim, mas é por aí que se torcem as razoes da governamentalidade. Ocorrências desses atos profanatórios durante a insurgência de Junho devem ter se multiplicado país afora. Por relato direto de manifestantes, sei de uma em Fortaleza, quando a onda de protesto se aproximou da praia proibida, a Arena Castelão, antes, durante e depois do jogo entre Brasil e México, dia 19 de junho - segundo os cronistas locais, a maior manifestação política na história da cidade. A alturas tantas, o caldo do confronto foi engrossado pela adesão de um enxame de pivetes - vetinhos, ou vetins - que capricharam num sem-número de manobras táticas, entre elas o sequestro de um ônibus, ato contínuo desviado na direção de um pelotão de cavalarianos da PM, não sem antes desembarcar os passageiros e confiscar-lhes os ingressos para o jogo. Mas como a barra da direção pesou mais do que podiam os braços do novo motorista, este pulou fora deixando um saldo devedor atravessado na pista, um dispositivo-bagulho fora do uso oficial. Já não foi assim tão pouco além de ampliar o repertório.

93. Sei muito bem que o MPL não é o princípio e o fim de todas as coisas, bem trou ser possível e realizável bem antes que o longo prazo nos mate a todos. E o que é ainda mais grave e inaceitável, nos marcos do capitalismo, como se diz na fraseologia da esquerda instalada eternamente na desvantagem da correlação de forças.

Seria um despropósito atribuir à concepção desbravadora de Henri Lefebvre uma versão barateada do Direito à Cidade, uma espécie de direito à visita ou acesso e usufruto daquilo que já existe, como David Harvey, por exemplo, costuma relembrar sempre que esse novo direito entra em cena a cada nova rodada de ocupe isso, ocupe aquilo. Assim que a tempestade amainou e os manifestantes entraram na linha pacifica do bom senso, o resumo bem raso de toda a ópera de Junho passou a ser a seguinte: "se, no início, ter um carro conferia ao seu proprietário pleno acesso a todas as oportunidades da vida urbana, em comparação com as condições dadas àqueles que usam os meios de transporte coletivo, hoje esta garantia não existe mais. Ainda que em condições mais vantajosas, os usuários de transporte individual também sofrem hoje para se deslocar, presos no congestionamento que eles mesmos provocam". Reflexão equilibrada e razoável como tantas outras na mesma direção, que só citei por ter sido publicada exatamente um ano antes das manifestações. Mas poderia ter evocado igualmente, porém na contramão do debate, entre várias outras nessa linha, a lembrança de Thiago Benicchio a respeito do momento em que "trânsito" começa a virar Mobilidade Urbana: "essa discussão sobre mobilidade urbana em São Paulo ganhou força nos últimos anos

como o famigerado mantra da Mobilidade Urbana. E que minha visão é muito paulista, para não dizer paulistana, mas não há nada que possa fazer a respeito. 
porque chegou a quem até então não era afetado por ela [...] quando essa pessoa [classe média moradora dos Jardins] começa a levar uma hora e meia para ir ao trabalho [distante a não mais de 5km, por exemplo] [...] isso se tornou um problema social. Identificado como "trânsito""94. Mas a fila já vinha andando faz algum tempo. O capital pode ser um mecanismo cego de acumulação como um fim em si mesmo, mas não erra o alvo nunca. Estava muito claro durante a campanha eleitoral de 2012. Não havia marqueteiro que não alertasse seu cliente: é o transporte coletivo, estúpido! E não se trata só de voto. É que a fronteira dos grandes negócios urbanos está se deslocando como sempre quando o excesso do ciclo anterior arrisca paralisar o motor da máquina de crescimento justamente no pesadelo da imobilidade total. Não seja por isso: sinal verde para a demonização do transporte individual, e meia volta dos fundos públicos para as devidas parcerias com o big business - modelagem financeira incluída - no setor dos "transportes em comum", como se diz em bom francês desmoralizando de quebra o "comum" dos novos comunistas -, a saber, no mesmo carrinho de compras: metrôs, monotrilhos, trens metropolitanos, ônibus e mais ônibus em corredores e faixas idem etc.

Noutras palavras, o espectro do apocalipse motorizado pode estar mudando de mãos. Encomendada a peso de ouro ao escritório do arquiteto estelar Sir Norman Foster, está sendo construída em Abu Dahbi, nos Emirados Árabes Unidos, a primeira cidade do planeta sem emissão de $\mathrm{CO}_{2}$, totalmente sustentável e tudo mais que se segue dessa palavrinha mágica. Mas sobretudo e antes de tudo, nela não haverá carros. As pessoas circularão numa es-

94. Apud Daniel Guimarães Tertschitsch (Op. cit.). pécie de bonde com paradas a cada duzentos metros circulando sobre trilhos magnéticos e movidos por energia solar. Serão os únicos veículos autorizados a circular, pois toda cidade pertencerá ao pedestre. Coroando sua reentronização, esta bem-aventurada criatura, o pedestre, terá à sua disposição uma ampla praça onde deambular à sombra de imensos guarda-sóis que seguirão o curso do sol até se fecharem ao anoitecer para liberar o calor absorvido durante o dia. Nesse cenário de mil e uma noites e energia limpa, o carro saiu solenemente de cena, banido para as trevas exteriores do mal absoluto enquanto estão de volta bondes e trilhos e tudo mais que puder confortar a imaginação apocalíptica dos integrados. Não é show room, tem até nome, Masdar City e está sendo de fato construída, porém lentamente, para tornar ainda mais devastador seu efeito demonstração. ${ }^{95}$ Se a moçada não ficar esperta e por descuido embarcar no realejo do "tudo pelo transporte coletivo" - como nos anos 80 mordemos a isca do "tudo pelo social", logo estaremos chovendo no molhado dos novos gestores do negócio "coletivo". A armadilha é poderosa. Mesmo Robert Kurz, num escrito memorável, "Sinal verde para o caos da crise"96, se deixou apanhar, de raspão é verdade. Visando o fetichista do automóvel e do progresso pela aceleração tecnológica da mobilidade, amarrou o destino do impulso ao movimento livre ao "lugar nenhum" característico do indivíduo modelado pelo moinho capitalista, totalmente sem rumo por não querer deixar preestabelecer a sua direção de viagem. Não custa prevenir, como se viu: mesmo o mais execrá-

95. Pedro Fiori Arantes. Arquitetura na Era Digital-Financeira: Desenho, canteiro e renda da forma. São Paulo, Editora 34, 2012, p.342-346.

96. Últimos combates, Petrópolis: Vozes, 1997. 
vel dos dispositivos, como a máquina-automóvel, nada poderia se não aprisionasse a seu modo, algum desejo demasiadamente humano de felicidade. Voltemos ao projeto Masdar City, uma porta só aparentemente muito fácil de arrombar. Se até o New York Times desconfia, ou pelo menos abre espaço para artigos "céticos" levantarem um pouco o véu que afinal recobre a culminação do conceito de gated community. Todavia, o abre-te-sésamo conjugado de carbono zero e car-free city, desenhado além do mais para hospedar a nata das companhias cleantech, torna irresistível o apoio dos Greenpeace e WWF da vida. E por aí vamos. ${ }^{97}$ Há um outro ponto cego nesse consenso em torno da demonização do carro, o dispositivo de governo das condutas que passou a ser combatido por esse mesmíssimo governo das populações entaladas nos mais diversos aparatos técnicos. O que não falta é material na internet sobre Masdar City. Prefiri no entanto uma outra fonte para a sumária descrição inicial, aliviando o recorte das devidas aspas para não ter que esclarecer de imediato sua origem, o filósofo francês Francis Wolff, que além do mais conhece muito bem o Brasil onde ensinou durante um bom tempo. Pois abordando o tema proposto num colóquio recente realizado em várias cidades brasileiras - "o futuro não é mais o que era", uma das tantas frases célebres de Paul Valéry acerca da mutação dos tempos entre as duas grandes guerras do século passado -, Francis Wolff abre sua comunicação contrapondo ao futuro sem

97. Para uma interpretação da nova constelação urbana em que proliferam esses “paraísos do mal” como os chamam Mike Davis e Daniel Monk, nos quais "os ricos podem andar como deuses no jardim de pesadelo de seus mais profundos e secretos desejos", ver Otília Arantes, Chai-na (São Paulo: Edusp, 2011, pp.50-53). A seu ver, esses espaços urbanos extremos alicerçados no trabalho atroz de imigrantes acampados fora dos muros são "casulos de ansiedade armada, num planeta de megacidades favelizadas” (cit. p.53.). carro de Masdar o desastre rodoviarista de Brasília, nosso futuro no passado ${ }^{98}$. Mas se Brasília era o futuro que chegou como um colapso, pelo menos era um futuro, e se deu no que deu, o seu eclipse não se deve exclusivamente à tendência entrópica de um sistema de exploração baseado em energia fóssil e transporte individual. Ao passo que na perenemente limpa e reciclável Masdar, cujos habitantes andam sobre trilhos, tanto no literal como no figurado, o único horizonte é o presente, embrulhado numa embalagem futurista que reforça ainda mais a couraça da precaução securitária que envolve todo esse aparato preventivo, filtrando os sinais ameaçadores que o futuro lhe envia. E, no entanto, há quem sonhe com esse estado de alerta e vigilância permanente, transposto é claro para latitudes menos inóspitas. Como o nosso filósofo, por certo cum grano salis: "sonhamos hoje com Masdar - ou melhor, sonhamos viver numa outra Masdar, longe dos Emirados, talvez perto de Paraty em algum lugar mágico entre Rio e São Paulo"99. "Luxe, calme et volupté"? A reminiscência viria a calhar, mas não procede: o convite do poeta à viagem em direção ao Novo foi feito numa era de expectativas crescentes, cujo horizonte encurtou até o grau zero da mais explosiva das emergências. Contra as quais justamente proliferam tais bolhas de sonho que Mike Davis e Daniel Monk batizaram de "paraísos do mal" e Otília Arantes, de "paraísos fora da lei”. Tudo somado, já que se trata de sonho e viagens, expectativas e experiências, o futuro há 50 anos e o presente indefinidamente expandido de hoje, a boa pergunta

98. "A flecha do tempo e o rio do tempo: pensar o futuro", em Adauto Novaes (org.), Mutações: o futuro não é mais o que era (São Paulo: Sesc, 2013, pp.41-43).

99. Ibidem, p.53. 
deveria ser: afinal, com o que sonha acordada e de olhos bem abertos, "a população trabalhadora humilhada pela CPTM", como escreveu em 2012 Ronan $^{100}$, se o pesadelo da imobilidade urbana baixou sobre todos motorizados e transportados? Irmanados num abraço de afogados, utopia e distopia explodem, mas até agora só explodem - sempre que a circulação retorna ao primeiro plano. PS: Leio num magazine francês de variedades que o projeto Masdar City encalhou, mas não o argumento, pelo simples fato de que rende meganegócios e alimenta campanhas eleitorais.

Por que pulamos a catraca? Porque a Tarifa Zero é uma utopia real ${ }^{\mathbf{1 0 1}}$. O que muda tudo. A começar - tendo em vista nosso exercício de imaginação política -, pela hipótese da nova insurgência profanatória que teria vindo desmanchar o consenso em torno do processo de paz armada - ou, se se preferir, pacificação - em curso no país e vulgarmente chamado de Transição, cujo aperfeiçoamento será por certo interminável ${ }^{102}$. Creio que São Paulo 1917

\section{Passa Palaura, 10 de abr.}

101. Na boa observação de João Alexandre Peschanski, "O transporte público gratuito, uma utopia real". In: Ermínia Maricato et. alii. Cidades rebeldes: Passe Livre e as manifestações que tomaram as ruas do Brasil (São Paulo: Boitempo, 2013, pp.59-63).

102. Vasculhando mais uma vez a floresta de prints à minha volta, vejo que não estou só na hipótese de que a partir de Junho difundiu-se a percepção de que uma ameaça rondava o consenso Paz e Oportunidade, sobre o qual se erguera a reconciliação nacional uma vez curadas, ou simplesmente entregues à própria sorte, as feridas da Ditadura. Refiro-me ao fecho de um artigo de Henrique Costa. À vista da ressalva acima (nota 93), vale destacar que o autor, embora pesquise na USP, argumenta com matéria colhida principalmente no rescaldo carioca de Junho, do qual aliás partimos nós também. Rescaldo no qual o oficialismo, tal como o fogo de barragem midiático contra vândalos, baderneiros e arruaceiros, aos quais, de resto, o pronunciamento presidencial de junho prometeu tolerância zero, estendida mais a diante à "guerra psicológica adversa", viu apenas "anomia niilista”, na bizarra expressão de um ideólogo de primeira linha, juntando-se aos correligionários que hoje "quebram a cabeça e Fortaleza 1935 deixaram claro que o simples gesto - por assim dizer, já que é o mais difícil de todos - de profanar um dispositivo de captura da livre circulação numa cidade segregada pela distribuição das funções do capital, libera uma carga de energia utópica que parece muito longe de esgotada - como diz a lenda difundida pelos coveiros da Teoria Crítica. A imensa novidade é que ela dessa vez não se dissolveu no ar. Por meio da ação direta e autônoma, condensou-se numa molécula cujo princípio ativo em duas semanas converteu uma marola de quatro a seis mil pessoas numa onda de um milhão e meio em mais de cento e vinte cidades. Não era o milênio, mas a queda de uma tarifa. Para ser preciso ${ }^{103}$, uma reversão da lógica da tarifa - outro ato profanatório? -, do seu aumento inercial, um ritual fetichista engolido pela população entra ano sai ano (Oh My God!, Abaixo da inflação!), para a sua redução crescente até o limite lógico da tarifa zero. E este limite lógico não é o cemitério do longo prazo, é um horizonte próximo, no qual todos os devaneios despertados pelo ato

para desvendar a arapuca que se tornou a conjuntura do Brasil, todos há pouco muito crentes de que o subproletariado garantiria vida eterna ao petismo no poder" - crença que certamente pressupunha igual vida eterna ao subproletariado, e vida eterna dentro da ordem. Como do sonhado casamento com a casta dita neodesenvolvimentista parece que não sobrou nem um troco para a condução, "seria preciso achar um culpado", nas palavras do autor. Sugerimos mais atrás um outro sonho, um sonho de paz: sonhava-se um mau sonho com esse culpado muito antes dele finalmente encarnar, na brecha aberta pela ruptura que talvez estejamos.

testemunhando, embora o curso do nosso pequeno mundo tenha reentrado nos eixos, como se pode ver pelo número de ônibus queimados diariamente. "Mas a corda, talvez, tenha finalmente estourado. A mobilização em torno ao sumiço do pedreiro Amarildo na favela da Rocinha mostra que, de junho para cá, a consciência ultrapassou a medida convencional da luta de classes aceita como natural no Brasil. A paz armada proporcionada pelas Unidades de Policia Pacificadora sofreu um abalo". Henrique Costa, "O presente e o futuro das jornadas de junho”, Carta Maior, 11 de ago. de 2013.

103. Como Pablo Ortellado, que assina o capítulo final do livro coletivo já citado, 20 centavos: a luta contra o aumento. 
de pular uma catraca - todas as catracas da separação operada pela mercadoria -, se materializam na real existência de uma cidade que só existia na expectativa de um dia se movimentar livremente por ela.

Se entendi alguma coisa da irrupção de Junho, não me surpreenderia reencontrar nos coletivos que planejaram tão bem a luta contra o aumento ${ }^{104}$ quem, não obstante o planejamento estratégico evocado agora, não se reconheça num manifesto de mutação histórica como o sugerido, por exemplo, pelas seguintes linhas: "há uma urgência nisso tudo [...] e agora há uma nova urgência, uma urgência do próprio tempo [...] as dimensões temporais do pensamento radical e revolucionário mudaram. Colocamos um crânio sobre as nossas mesas, como os monges de antigamente, não para glorificar a morte, mas para nos focarmos no perigo iminente e intensificar a luta pela vida. Não faz mais sentido falar em paciência [grifo meu, nem mesmo do Conceito] como uma virtude revolucionária ou falar sobre 'revolução futura'. Que futuro? Precisamos da revolução agora, aqui e agora. Tão absurdo, tão necessário. Tão óbvio."105 Então: não obstante o planejamento estratégico vírgula, por isso mesmo. A utopia real de que começamos a falar é também esse agora de um parado-

104. Nas palavras de Lucas de Oliveira, na entrevista feita por Maria Carlotto: "a gente acertou até mesmo o dia em que o aumento ia cair. $O$ aumento caiu no dia em que nós planejamos, de verdade. Foi um planejamento muito sistemático. Nós olhamos para o que aconteceu nas cidades que conseguiram barrar o aumento. O que aconteceu nessas cidades? Uma luta forte e intensa, em tanto tempo, e o grupo que chamou inicialmente as manifestações, a partir de um dado momento, não teve mais o controle sobre elas. Então depois de estudar essas experiências, a gente concluiu: é isso que a gente precisa em São Paulo.”

105. John Holloway, Fissurar o capitalismo (São Paulo: Publisher, 2013, p.8, tradução Daniel Cunha). xal raio em céu azul calculado até na sua voltagem. ${ }^{106} \mathrm{As}$ sucessivas revoltas da catraca que culminaram na vitória de Junho reconverteram o horizonte remoto desta expectativa numa utopia real. Ao ressaltar o forte componente utópico de uma proposta [quem diria] como a do transporte coletivo gratuito, e nada menos utópico do que uma política pública, cuja única razão de ser é incrementar a governabilidade das condutas, e estamos falando de "condução", o autor citado há pouco, Alexandre Peschanski, remete a uma especificação desse "real" na utopia, à definição de Olin Wright: "O real em 'utopia real' também explora alternativas [utópicas] para instituições dominantes, mas focam no problema da dinâmica das consequências não-intencionais e autodestrutivas"107. A Tarifa

106. Ao contrario das reticências - para ser ameno - de realistas e pragmáticos, Holloway não está pregando o Sermão da Montanha ao dizer que é preciso mudar o mundo sem buscar redesenhar as estruturas de poder e de dominação para melhor colocá-las "a nosso serviço", como lembrado por Julio Delmanto, resenhando o livro em novembro último (2013), "Ótima hora para fissurar o capitalismo" (na rede, não sei ao certo onde). Ótima hora não no horário estadocêntrico nacional, mas no calendário de Junho, que não por acaso talvez tenha assinalado essa mudança na temporalidade da rebelião, cuja conflitividade em nova chave tanto seu inimigos como (sobretudo) seus amigos querem “estatizar". Foi sim por 20 centavos, mas não por Mais Estado!

107. Erik Olin Wright, "Utopias reais para uma sociologia global”, Diálogo Global, Vol. 1, jul. de 2011. Não creio forçar demais a mão se acrescentar que essa exploração prática em busca de utopias reais, ao "identificar configurações existentes que violam as lógicas básicas das instituições dominantes”, não deixa de ser uma estratégia de profanação que por sua vez, nada mais tem a ver com a grandiloquência das tabula rasa do passado. Decididamente, os atos profanatórios identificados e convocados na pequena Nota profética de Sílvio Mieli não têm nada a ver com as transgressões características das vanguardas, históricas ou requentadas, conhecemos seu destino de progressiva perda de tensão e voltagem, até que a Indústria Cultural complete o serviço de abolição da distância estética que antes apartava as obras consagradas do comum dos mortais. Sirva novamente de advertência a armadilha proibicionista das car-free cities: o complexo político-industrial do transporte coletivo está aí operando e "profanando" as separações que caducarem. O efeito demonstração de Masdar City é uma inequívoca manifestação sobrevivencialista: descartando o aterro sanitário social acima do qual flutuam, os super-ricos estão mostrando que o capitalismo pode não ser necessariamente uma 
Zero seria assim um antidispositivo híbrido, uma política pública autodestrutiva, mas autodestrutiva enquanto política pública, sendo o limite lógico da tarifa zero uma cidade fora do limite do capital.

Mas pode não ser, como relembra Alexandre Peschanski. Do ponto de vista econômico, o transporte público gratuito não só não é incompatível com o capitalismo como até desejável e viável. Aliás Lucas de Oliveira, na mesma entrevista com Maria Carlotto também lembrava que recentemente, um economista do BNDES publicara um artigo na Folha de São Paulo chamado "Ônibus gratuito". "O que ele fala? Que o ônibus de graça desenvolveria a economia da cidade porque mais gente circularia. As pessoas gastariam o dinheiro do transporte em outras coisas, teriam uma mobilidade social maior, tendo uma mobilidade maior, aumentaria o PIB, aumentando o PIB aumenta a arrecadação, então a médio e longo prazo se paga”. O real obstáculo a esta proposta de componente utópico diz respeito às relações de poder no capitalismo. Obstáculo cuja primeira barreira, mas só a primeira, foi transposto pela ação direta nas ruas. Um processo horizontal e autônomo, estrategicamente planejado para perder o controle da situação numa explosão antissistêmica, alcança finalmente um resultado tangível de alívio prático imediato num contexto de sofrimento social intenso.

Como indicado, sobre essa confluência finalmente realizada entre processo e resultado - depois de uma larga temporada em que os novos movimentos anticapitalistas

sociedade do automóvel. Porém não mede sacrifícios (alheios) para acumular proibições: tabaco, droga, carro, etc., a lista varia conforme dá voltas a espiral da crise. Multiplicando os zoneamentos de segurança: assim, numa cidade livre de veículos movidos a energia fóssil, será proibida a entrada de viventes e semoventes poluidores. sobrevalorizaram o processo, entendido e praticado como um “comunismo pré-figurativo" (Carl Boggs) em detrimento do resultado -, ver o capítulo de Pablo Ortellado. Para uma conclusão na mesma direção, o artigo de Rodrigo Guimarães Nunes, que passo ato contínuo a citar para então voltar à interpretação de Pablo Ortellado. "Ao contrario de um Occupy Wall Street, que durante meses discutiu se era legítimo apresentar demandas, o movimento brasileiro desde o início teve algumas claramente definidas: fim das tarifas, fim das remoções, desmilitarização da polícia [...], a riqueza dessa luta, que lhe permitiu assumir ressonância tão ampla, está em partir de um objetivo claro, imediato e amplamente consensual (redução das tarifas) para uma discussão mais ampla (lucro das empresas, qualidade dos transportes) e objetivos de médio prazo (abertura das planilhas, passe livre para alguns setores etc.), apontando sempre para uma transformação radical das relações entre capital e trabalho, população e Estado (transporte de qualidade gratuito, financiado pela redução do lucro das empresas e impostos progressivos)". ${ }^{108}$ Realmente bizarra insurgência, tão longe e tão perto. Afinal que horizonte é esse? O mesmo Rodrigo Nunes oferece uma pista preciosa a respeito da esquina que estamos dobrando. Agora que a fórmula gasta escapou, o jeito é explorar o ato falho. Esquina da História são palavras de granito, daí a maiúscula. Esquinas e degraus se alternavam então na marcação de um tempo político ascensional. Hoje um Acontecimento como o Junho brasileiro é o seu próprio horizonte. O pacote filosófico de que se extraiu

108. Rodrigo Guimarães Nunes, "A organização dos sem organização: oito conceitos para pensar o “inverno brasileiro'”, Le Monde Diplomatique.org. br, jul. de 2013 . 
este juízo sobre o presentismo dos acontecimentos de Junho não precisa ser desembrulhado agora - estamos vendo o filme, aliás narrado enquanto transcorria. Vem daí a centralidade da mídia e não se trata de conspiração que aliás nela é congênita, não é uma patologia exclusiva de uma localização no espectro ideológico. Com o perdão do mau trocadilho, estamos falando da decisão nada épica ou heroica tomada numa manifestação de rua digamos, historicamente desorientada, de dobrar nesta esquina e não naquela outra, ocupar uma Câmara Municipal ou seguir em frente etc. Ou melhor, quem está falando é o nosso autor, Rodrigo Nunes, rebatendo as críticas à falta de "direção" do movimento, segundo a cartilha conhecida: “apenas organizações de massa podem ter ‘direção'; apenas uma estrutura formal de liderança, como a destas organizações, é capaz de formar uma vontade coletiva; na ausência destas organizações, há apenas ou uma multidão de átomos, ou uma turba disforme, facilmente manipulável". Saudade eterna deixada pelo Século dos Chefes. (Estou citando o título de um livro notável de Yves Cohen). Não vou esmiuçar a original anatomia da massa em movimento proposta por Rodrigo ${ }^{\mathbf{1 0 9}}$, embora seja tentador, sobretudo por sua "direcionalidade" se contrapor, e por aí assinalando a virada histórica que está nos concernindo, à marcha proletária militarizada analisada por Virilio. Seja como for, o tamanho do abalo explica a virulência das restrições: "Os partidos, sindicatos e movimentos organizados, que se julgavam detentores exclusivos do poder de mobilizar multidões, em que pese sua visível decadência neste sentido, depararam com o impensável: um movimento de massa sem organizações de massa”. Contrapro-

109. Que para tal remete a um artigo seu, "Las lecciones del 2011: tres tesis sobre organización", El Ciudadano. va desse fosso dramático que se aprofunda? O fiasco da Jornada Nacional de Luta de 11 de julho de 2013, convocada pelas organizações da esquerda histórica - alias "fiasco", Jair Menegheli dixit em entrevista ao jornal O Estado de São Paulo, por ocasião dos trinta anos da CUT. O descompasso revela muito da disjunção dos tempos de que estamos falando. Salvo erro nas contas, somente dez dias depois do primeiro auge das manifestações caiu a ficha e uma plenária foi convocada para "começar a costurar uma plataforma unitária que pautasse [sic] os movimentos nas ruas", como se pôde ler na imprensa de esquerda. Qual a pauta? Um mamute de sete cabeças: "10\% do PIB para educação; investimentos em saúde; redução da jornada de trabalho; transporte público; reforma agrária; fim do fator previdenciário; reforma política; reforma urbana; democratização dos meios de comunicação; contra a PEC da terceirização e contra os leilões de petróleo". Todas as demandas obviamente fazem sentido e são notoriamente progressistas. Num cer to sentido e no seu conjunto, elas são o progressismo brasileiro. E, no entanto, dos milhões de um mês atrás, nem sombra. Por assim dizer, é claro. Para contrabalançar, fiquemos com a avaliação de Lincoln Secco: “diante das manifestações de junho, as centrais sindicais convocaram uma greve geral para o dia 11 de julho, algo que não ocorria desde 1991. Cerca de 200.000 pessoas participaram das manifestações em 57 cidades. A abrangência geográfica foi maior que a dos protestos de junho, embora o número de manifestantes fosse menor. Mas o impacto da greve foi maior devido à paralização de transportes públicos em algumas capitais e pelo bloqueio de rodovias na maioria dos estados da federa- 
ção."110 Avaliação clássica no melhor sentido do termo, precedida de uma outra: "até o fim de junho nenhuma greve importante acompanhou os protestos de rua-é preciso lembrar que em 2012 houve 58\% mais greves do que em 2011. Os movimentos sociais e os grupos da periferia das grandes cidades ficaram em compasso de espera". É questão de verificar. Em todo caso, não se trata de Fla-Flu. A medida em que se alarga o desencontro histórico entre a esquerda produtivista e a esquerda anticapitalista, vamos cavando nossa sepultura, ora com a mão direita, ora com a mão esquerda. O descompasso não poderia ser maior, sobretudo levando-se em conta a presença na rua de um novo e jovem proletariado, de escolaridade mais alta que a renda, entre outros atributos dissonantes identificados pelos especialistas. Na vasta literatura a respeito da entrada em cena deste novo personagem, será sugestivo confrontar um ponto de vista mais assertivo, "À sombra do precariado", de Ruy Braga ${ }^{111}$, e outro mais recente, "Brasil, junho 2013: classes e ideologias cruzadas", de André Singer ${ }^{112}$. Descompasso enfim entre forma e conteúdo como se depreende, entre tantas outras declarações de divórcio de parte a parte, desta fala de Mayara Vivian (MPL): "o fato de esses atos terem sido muito grandes e contagiados [sic] tem a ver com a forma política que nós tomamos, porque a forma não está dissociada do conteúdo [...] A gente construiu uma nova cara, porque as pessoas se sentiram à vontade para estar naquele espaço, porque não

110. Lincoln Secco, “As jornadas de junho”, Em: Ermínia Maricato et. alii, Cidades rebeldes: Passe Livre e as manifestações que tomaram as ruas do Brasil. (São Paulo: Boitempo, 2013).

111. Idem. pp.79-82.

112. Novos Estudos, CEBRAP, n. 97, nov 2013. tinha ali um carro de som vomitando um monte de abobrinhas na orelha delas. É, sim, uma nova forma política". ${ }^{113}$ Corrigindo: adequação entre forma e conteúdo dos dois lados. Quanto à praga do carro de som, chama atenção o fato de que seus adeptos, comprovando o argumento apenas sugerido linhas acima acerca do novo regime temporal do acontecimento político, projetarem a mesma lógica da voz condutora na paranóia da mídia manipuladora. Não sei se o carro de som é da mesma família do trio elétrico, todavia são parentes na distribuição pelo alto do som que faz as pessoas dançarem à volta, seja palavra de ordem, seja refrão de música padronizada. Tampouco é meramente anedótica implicância com bandeira de partido. Bem como a aflitiva insistência do outro lado. Quase um automatismo, neste último caso, aliás extremo: tudo se passa como se delegássemos a bandeiras e organizações, a esta altura mais rituais do que símbolos de um processo em marcha, a incumbência de acreditar por nós, enquanto vamos tocando nossas tarefas e agitando nossas bandeiras - adaptando, para o caso presente, as observações de Silvia Viana acerca da "espantosa importância que subitamente adquiriram as cores de nossas vestes", creditando a dança inócua de tecidos e bandeiras na conta da política de administração de logos e campanhas. ${ }^{114}$

Como lembrado, o foco de Pablo Ortellado, no último capítulo do livro coletivo sobre a luta contra o aumento na tarifa dos transportes, também era uma questão de adequação entre forma e conteúdo: vencemos porque do princípio ao fim dizíamos que queríamos a revogação dos

113. Debate no Espaço Revista CULT, "O que pensam os jovens que ocupam as ruas?”, Cult, n. 182 ago. de 2013. p.64.

114. “A guerra dos panos”, jun. de 2013, Blog da Boitempo. 
20 centavos de aumento, nada mais nada menos, evidenciando no entanto a cada demonstração que tampouco negociávamos a carta anticapitalista pela qual se norteava a autonomia de todo aquele processo de ação direta. (Mais adiante veremos que este não é o único foco na sua importante avaliação do legado dos protestos de junho). Numa palavra, vencemos, ainda parafraseando o autor, porque soubemos conciliar a preservação da lógica libertária da autonomia, cujo horizonte nunca é menos elevado do que a desmercantilização da vida, com a meta "curta" de uma revogação cifrada em menos 20 centavos. Na praça Tahir havia uma única demanda: a saída de Mubarak. À pergunta lançada aos ativistas do Occupy Wall Street, "qual é nossa única demanda?", depois de muitos comunicados ziguezagueantes o movimento anunciou enfim sua única demanda: "acabar com a pena de morte é nossa única demanda... acabar com a desigualdade de renda é nossa única demanda... acabar com a pobreza é nossa única demanda... acabar com a guerra é nossa única demanda." Aos olhos do autor, passaram um atestado de cegueira tática e estratégica, ao contrário do MPL que saiu à rua em busca de um resultado. "Os sonhos dos ocupantes não cabiam em uma demanda única. O movimento decidiu que não queria os seus 20 centavos", conclui Pablo. Desafiada por Junho que lhe roubou as ruas, a esquerda histórica brasileira fez subir aos céus de Brasília uma estrela de onze pontas, o resumo numa única jornada de todo o Projeto Democrático Popular velho de guerra: o eclipse foi visível a olho nu, descontadas todas as ocorrências promissoras elencadas por Lincoln Secco. Depois de Junho, veremos quem (e como) sairá atrás de seus 20 centavos, que sem dúvida não é fácil encontrar. Os herdeiros de Seattle, ou Salvador/Florianópolis, levaram uma década para des- cobrir que não é nem a Economia, nem a Questão Urbana (estúpido?), mas os 20 centavos. Mas para tanto, como já vimos, foi necessário que vários consensos-tabu fossem quebrados ao longo do processo, abrindo caminho até esse resultado. As profanações do visionário Sílvio Mieli - pelo menos naquela Nota ainda mais enigmática por parecer contrabandeada no espaço que a acolheu. Logo veremos a mais sacrílega delas: a profanação da estratégia da não-violência. Mais uma vez: jamais esquecer, como se esqueceu na hora em que a tática Black bloc tornou-se a bola da vez, a dimensão inédita assumida pela tática da ação direta adotada pelo MST - ocupar, resistir, produzir -, que lhe rendeu de volta a fúria assassina dos proprietários e seu braço estatal. Me pergunto se a rememoração de Pablo Ortellado em torno da tensão entre processo e resultado, ao se deter no marco simbólico que foi a Marcha Sobre o Pentágono em 1967, também não tocou num aspecto importante das profanações políticas de agora, ao que parece nascidas naquela marcha batida rumo a Maio de 68, na sua definição, "a capacidade mobilizadora da performance contracultural, além da sua potencia processual de pura diversão", evocada a propósito da sugestão de algumas cabeças de vento de fazer o Pentágono levitar com milhares de pessoas entoando o mantra "Om", descartada por se tratar de incompreensível futilidade que poria a perder anos de trabalho de conscientização contra a guerra no Vietnã. Sabemos que depois de quase três décadas de hibernação, essa potência processual voltou à superfície com as heresias políticas do Zapatismo para reemergir em Seattle e por fim desembarcar em São Paulo no início dos anos 2000 cavando nos subterrâneos da avenida Paulista até ressurgir nas campanhas preparatórias de junho já nos anos 10 deste século. 
Com a palavra o próprio MPL: "a cidade é usada como arma para sua própria retomada: sabendo que o bloqueio de um mero cruzamento compromete toda a circulação, a população lança contra si mesma o sistema de transporte caótico das metrópoles [...] é assim, na ação direta da população sobre sua vida - e não a portas fechadas, nos conselhos municipais engenhosamente instruídos pelas prefeituras ou em qualquer uma das outras artimanhas institucionais -, que se dá a verdadeira gestão popular. Foi precisamente isso que aconteceu em São Paulo quando, em junho de 2013, o povo, tomando as ruas, trouxe para si a gestão da política tarifária do município e revogou o decreto do Prefeito que aumentara a passagem em 20 centavos." ${ }^{115}$ Principiamos por uma astúcia clássica - mas agora, a da razão insurgente -, o bloqueio que se volta contra si mesmo para obter o efeito oposto, a imobilização como antecâmara disruptiva da livre circulação, posta no entanto em movimento pelo choque direto, pelo confronto sem mediações, processo ao longo do qual "as pessoas assumem coletivamente as rédeas da organização de seu próprio cotidiano"116, para então ultrapassar um limiar inédito, o da "verdadeira gestão popular", no caso, da política tarifária. Veremos, quando chegar a hora das novas licitações exigidas pela legislação, em que pé estará essa gestão às avessas, mas nem por isso menos gestão. A proposta de componente utópico seria então a prática concreta da gestão popular? Essa a utopia real prestes a se materializar numa cidade sem catracas? Insurgência passou

116. Idem Ibidem. 
a rimar com gestão? ${ }^{117}$ Não é sarcasmo mas reticência objetiva. A contrarrevolução sem revolução em curso há três décadas, que apenas padecemos e não vemos mais, gira precisamente em torno de uma reviravolta gerencial de tudo e qualquer coisa "governável", a começar pela força de trabalho que circula por um sistema de catracas chamado cidade. Numa palavra, nunca fomos tão governados. Gestão sem governo então? Por enquanto um enigma, de cuja solução apenas encaminhada dispomos desde Junho de um imenso ensaio geral. Fica a descoberta atônita de que a insurgência que vem, ou está chegando, envolve um momento perturbador de desgoverno, de abalo sísmico do regime normativo dominante: simples-

117. Espero não estar armando um falso problema. Com a palavra novamente quem de direito: "Uma outra coisa que eu acho fundamental: ninguém pergunta para um movimento de moradia como você vai custear a reforma urbana, ninguém pergunta por que não é função do movimento social ser gestor público. A gente não quer ser gestor público. Dar opções e discutir isso politicamente, até porque a gente estuda o tema, tudo bem. Mas a função essencial do movimento social é mobilizar politicamente para garantir uma demanda, e criar formas de organização para isso, e não gerir o Estado", Lucas de Oliveira, entrevista citada com Maria Carlotto. Acredito, mas faltou acertar o relógio com o discurso do MPL no capítulo que lhe coube no livro Cidades rebeldes. Seja como for, uma coisa parece clara: o personagem cujo papel não se quer representar - e que tem a idade histórica da reinvenção pela esquerda da "política pública", como foi rebatizada e aclimatada a ação pública dos dominantes numa sociedade antagônica -, o gestor público, continua em cena, e com ele se discutirá igualmente em cena aberta. Uma outra coisa também deveria estar clara: se de fato está acontecendo uma ruptura com as tecnologias sociais de poder normalizadas ao longo de nossa interminável Transição, junto com os ônibus, também estão queimando as pontes que nos reconduziriam de volta a um novo marco zero da longa marcha através das instituições iniciada lá atrás pela esquerda de governo, no seu tempo uma tremenda novidade, hoje soterrada por uma avalanche de lugares comuns fossilizados. Vasto assunto à espera de um juízo histórico por parte de uma tradição crítica, equipada com um filtro mágico, específico das configurações periféricas, através do qual o serviço público e seu Estado suscitaram verdadeiras vocações para a responsabilidade, como se dizia, produzindo inclusive conhecimento novo sobre um país envenenado pela herança colonial. A famigerada reforma gerencial do Estado, ou seu simulacro, pouco importa, que pôs nos trilhos o seu contrário, o nosso crony capitalism, foi inspirada pelos herdeiros dessa mesmíssima tradição crítica. mente não queremos mais ser governados, ou não mais assim $^{118}$. Daí soar como um escárnio grotesco o reflexo pavloviano da Reforma Política, toda vez que parece tocar a campainha salivadora do "vocês não me representam".

6.

A utopia real armazenada numa proposta tão disparatada quanto sensata não teria surgido no horizonte se o tabu da luta política na rua não tivesse caído. Foram mais de duas décadas de sono dogmático. A regressão ao longo de nossa transição permanente foi tão avassaladora - há quem fale até numa sorte de retrocesso antropológico a propósito da involução que então se cumpriu em nossa capacidade de agir, em proveito da propensão a fazer cada vez mais coisas, no geral prescritas por um comando invisível ${ }^{119}$ - que

118. Digamos que em Junho - sob a espécie sensível de 20 centavos a mais resistiu-se a continuar sendo governado assim, e quase tudo consiste em saber decifrar retrospectivamente um tal "assim". O novo se insinuou por essa brecha, não custa repetir. Daí o espanto, expresso inclusive numa linguagem que ninguém mais estava acostumado a ouvir, ou melhor, nem sabia que ainda existia. Daí o espanto suplementar de ler essas linhas na revista Piauí, de jul. de 2013, p.8: “A situação que se abriu é revolucionária. Nela, o inesperado é sempre a nota inicial. [...] isso não significa que o Brasil esteja às vésperas de uma revolução, longe disso. Situação revolucionária não quer dizer tomada de poder. Muito menos a mudança radical da sociedade. A expressão serve para descrever o período em que o povo dá mostras de que não quer mais viver como antes. E que o Estado não pode mais seguir governando como fazia até então. Isso está a acontecer no Brasil", Mário Sergio Conti, "Rebelião".

119. Esse fazer coisas está longe de ser inócuo - embora o seja visto pelo ângulo do que se perdeu -, trata-se de uma "nova forma de política", condizente com o tempo novo do futuro que já chegou, prescrita por ONGs, Corporações e Estado aos jovens que irão "protagonizar" alguma atividade em que bens e serviços serão oferecidos gratuitamente, por exemplo, na forma de trabalho 
mesmo nos observadores menos anestesiados, a tendência inicial é sempre a de trivializar o acontecido em Junho, percepção niveladora encaminhada aliás pela banalização da presença dos jovens nas ruas de uns tempos para cá. Desde então, uma das coisas prioritárias a fazer, no geral multiplicadas na forma de "eventos", tem sido ocupar os jovens nos fins de semana justo com a "ocupação" de um espaço público convenientemente selecionado para a "atividade”. Tudo virou ocupação - até residência em teatro, e o que era para ser solidariedade foi se tornando rubrica em planilha, embora o termo "residência", de inspiração hospitalar, já não fosse menos infeliz. Ocupações intransitivas, portanto, de sorte que a "bandeira" (é preciso ter uma sempre, fora as carimbadas pelos partidos de praxe) que une os jovens agrupados em tais ocupações só pode ser a própria ocupação. Mobilizações em torno do nada como as chamou Silvia Viana ${ }^{\mathbf{1 2 0}}$. Mas é precisamente disso que

voluntário. Ver a respeito dessa máquina de fabricar consensos - mais um dos atuais dispositivos de governo -, o impressionante panorama analisado por Regina Magalhães de Sousa, O discurso do protagonismo juvenil (São Paulo: Paulus, 2008).

120. "Será que formulamos mal a pergunta", Em: Cidades rebeldes, p.56. No rol desses falsos precursores dos acontecimentos que marcaram 2013 como "o ano em que começamos a vencer" (Erica, MPL, "A tarefa é fortalecer as lutas sociais", cit. p.36) predominam empreendimentos ditos colaborativos, e via de regra ligados à produção cultural e editais conexos, especializados em proclamar a seu modo um direito à cidade na forma de ocupações de espaços públicos nas quais se celebra o fato de estarem juntos naquele espaço fazendo alguma coisa mais ou menos indefinida, geralmente um festival de música com cara de ato público ou vice versa. Podemos dizer quase sem erro que essa "ida à rua" está na origem da difusão daquela maquiagem do Direito à Cidade, mencionada páginas atrás, com cara de direito à visita e usufruto da paisagem urbana e seus equipamentos. A declaração de um animador destas manifestações-culturais-espontâneas-que-estão-transformando-a-cidade de São Paulo, transcrita por Silvia Viana, pode servir de ilustração igualmente espontânea do mosaico de estereótipos que movimentam o discurso analisado no livro de Regina Magalhães de Sousa: “Os jovens estão cada vez mais presentes nas ruas. Hoje temos grandes movimentos coletivos que contribuem para fortalecer a integração. Quando as pessoas ocupam os espaços, conseguem se trata, como logo adiante veremos, que não haja nada no centro do redemoinho. Foi dessa maneira que se inventou o protesto sem protesto, como conclui a mesma autora. ${ }^{121}$

Pôr jovens na rua era e é um negócio, mas como toda economia é política, o segredo desse negócio é a mobilização enquanto tal, tanto faz se movidas a editais, ONGs oficiais, isso ou aquilo em rede, programas assim ou assado de alguma secretaria ou ministério, e por aí vamos, entra ano e sai ano nessa espantosa fábrica de consensos e consentimentos em que o país se converteu. E de baixo para

transformá-lo e acabam se tornando protagonistas." Na contramão vinham outras Marchas, a da Maconha, a das Vadias etc., salvo engano, herdeiras em linha direta dos protestos antiglobalização de 2000 (SP, Praça da República, S26) e 2001 (SP, Avenida Paulista, A20), para ficar nos pioneiros. No primeiro, mil pessoas protestaram em frente à Bolsa de Valores, com tintas e pedras sendo arremessadas na sede da referida instituição, e 39 manifestantes presos depois de ocuparem o centro da cidade por toda a tarde. Na avenida Paulista, no ano seguinte, foram dois mil jovens. A polícia abriu então a sua nova caixa de ferramentas pacificadoras: 79 presos e mais de 100 feridos [Dados e histórico em André Ryoki e Pablo Ortellado, Estamos vencendo! Resistência global no Brasil, São Paulo: Conrad, 2004], só que dessa vez, como lembrado por um dos autores, a prefiguração anticapitalista encenada pelo processo alcançou um resultado anunciado desde o início, de sorte que os jovens manifestantes pela primeira vez não apanharam sozinhos, tampouco havia "protagonistas" de qualquer espécie. Como respondeu um militante à bisbilhotice fulanizadora de um repórter: "anota aí: eu sou ninguém". O comentário de Peter Pál Pelbart, depois de lembrar o acerto homérico do manifestante ao ressuscitar em pleno tumulto de rua a astúcia de Ulysses com o próprio nome Odisseu (Ninguém), ressalta o quanto a luta para tornar cada vez mais comum o que é comum, ao contagiar o próprio nome comum de quem luta, desnorteia os "dispositivos" que se lançam sobre ele. Peter Pál Pelbart, "Anota aí: eu sou ninguém”, Folha de São Paulo, 19 de jul. de 2013, p.A3.

121. Como um rally que reuniu a menos de um par de anos atrás no Largo da Batata (Zona Oeste de São Paulo) - por onde começou aliás a megamanifestação de 17 de junho - um punhado de desavisados mais ou menos convencidos de que estavam ali para exprimir seu desconforto com os rumos tomados pela reurbanização do largo e seu entorno, tudo em nome do tal direito à cidade. Seria o caso então de remeter desde já os escaldados por tais banhos de espaço público, ao projeto jornalístico investigativo Arquitetura da Gentrificação (ver o texto de Frabricio Muriana e Sabrina Duran, "PPP da habitação ..." no Blog, Arquitetura da gentrificação - Projeto Brasil) - e no tal rally ninguém sabia ao certo se era a favor ou contra a dita revitalização do Largo. 
cima, desde o chão da fábrica social. Numa sociedade-empresa, tudo se mobiliza a partir desta matriz, e pelo envolvimento através do zelo dos esfolados, pois não há outro jeito de tolerar o intolerável do que participando, e não há melhor escola de cooperação do que o próprio trabalho. ${ }^{122}$ Contrapondo-se à onda de movimentos que reivindicam a cidade por meio de organizações, no geral em rede, ligadas à produção cultural, o coletivo Passa Palaura foi direto ao ponto cego dessa coreografia urbana: "desde há muito tempo que o capitalismo não se reafirma como forma social unicamente através da repressão. De tempos em tempos, as técnicas de poder precisam ser renovadas e, ao contrário do que se poderia supor, a principal característica destas novas (ou não tão novas) engenharias de controle não consiste mais em manter os dominados imóveis e apáticos frente aos problemas sociais. Ao contrário, tanto mais ela funcionará quanto mais mantiver os de baixo engajados e participativos contanto que isto aconteça dentro de espaços preestabelecidos. É trazendo para a luz iniciativas que antes ocorriam à sombra que as empresas e os governos asseguram a manutenção de seus privilégios. E, em se tratando de forças renovadoras, a atuação sobre a juventude ganha especial importância". ${ }^{123}$ Um dos choques insurgentes de Junho consistiu justamente na profanação desse confinamento. Mudou-se o curso da mobilização, fazendo a moçada adestrada por sucessivas idas forjadas à rua, voltar mais uma vez às ruas como de hábi-

122. Ver entre outras boas análises, a de Rafael Alves da Silva, A exaustão de Sísifo: gestão produtiva, trabalhador contemporâneo e novas formas de controle, dissertação de mestrado, Unicamp, 2008.

123. "Existe consenso em São Paulo? reflexões sobre a questão da cultura”, segunda parte, 18 de fev. de 2014. to, mas agora na direção oposta. Não foi da noite pro dia. Fazia algum tempo que outras marchas também vinham vindo na contramão, pois então foi como tirar o dedo de um dique, como lembrado, prestes a se romper, quebrou-se o feitiço. "Existiam alguns consensos quando a gente começou a luta contra o aumento. Um deles é que as mudanças se faziam por dentro das instituições, por dentro do Estado ou por meio das eleições. Não seria possível barrar o aumento e a maioria da sociedade apoiava as medidas do governo. Esses três consensos caíram em 13 dias"124, no que emenda a constatação dos jornalista Cristiano Navarro, Luis Brasilino e Renato Godoy: "As mobilizações pela redução das tarifas reintroduziram estratégias de lutas nas ruas até então abandonadas no país. Com a força de um tsunami, o povo trocou abaixo-assinados, lobbies e petições online por marchas, cartazes, pedras e pichações em disputa física pelo rumo da sociedade."125 Dito isso, estamos longe de desatar o nó, a conversão do extraordinário em cotidiano, na fórmula inspirada do Maurício Carvalho, do movimento Juntos! ${ }^{126}$. E quem assim formulou o programa do próximo passo depois dessas semanas milagrosas de "renascimento libertário da rua"127, certamente não tinha em vista algum equivalente daquilo que os sociólogos, leitores ou não de Weber, gostariam de chamar e ver acontecer, uma rotinização do carisma, que sem

124. Gabriel Simeoni, MTST, "A tarefa é fortalecer as lutas sociais, jovens que organizaram os atos pelo Passe Livre falam sobre as maiores manifestações vistas no país", Caros Amigos, jul. de 2013, p.32.

125. “O jun. de 2013”, Le Monde Diplomatique Brasil, jul. de 103, p.5.

126. Em: "A tarefa é fortalecer as lutas sociais...":, cit., p. 36.

127. Douglas Anfra, "Renascimento libertário da rua", revista Mouro (no prelo). 
dúvida está à espreita, como atesta o simples tropeço na palavra "gestão" e seus derivados, para não falar na areia movediça da participação. No caso da juventude que foi para a rua, o melhor meio de governá-la, como tentou mostrar Fábio Candotti. Como as ruas não podem ficar o tempo todo ocupadas, o que fazer? O fato é que as duas semanas "em que começamos a vencer", quando caíram em treze dias os consensos da "política", tal como a conhecíamos e consensualmente reforçávamos a sua existência numa esfera separada de poder (Estado, instituições, eleições), deixaram uma herança sem receita, um acerto histórico com cara de pedra no caminho. É só comparar: ao contrário dos Indignados europeus, que continuam com razão indignados e ocupando praças conforme vai apertando o garrote da austeridade, a rua brasileira tinha uma agenda precisa de apenas 20 centavos, porém do tamanho de todo um ciclo de humilhações no transporte público e privações de toda sorte. E o fato não tão simples assim de estar junto nas ruas pôs em circulação um poder ainda não identificado. Uma experiência inédita que a inércia da pergunta clássica, tributária do antigo regime abalado, mas não abolido, irá por certo esterilizar: a partir de agora como ele vai ser exercido, esse poder construído pelas ruas? Apostando no rejuvenescimento do modelo participativo? Mas se até mesmo quem aposta nessa alternativa que estimula a participação mas não dá poder e parece que foi enterrada de vez em junho, , está com a pulga atrás da orelha? Quanto a seus coveiros tampouco têm resposta, tanto quando encaram como quando negam sua condição de gestores públicos virtuais. Não por insuficiência congênita, mas porque a pergunta pelo poder e seu exercício no governo dos homens e administração das coisas é velha de quase dois séculos.
Mobilizar desmobilizando, ou desmobilizar mobilizando? Bem que a Sônia Fleury, referência no âmbito das políticas sociais, avisou. Mais ou menos nos seguintes termos. Em princípio, conseguimos inscrever na Constituição de 1988 "todo um formato deliberativo e participativo de controle da sociedade sobre o Estado". E continuamos ativando isso todo tempo, multiplicando todo tipo de Conferências Nacionais disso e daquilo, porém o real poder de decisão estava passando cada vez mais longe desses tais espaços participativos, se é que algum dia passou de fato. Um bom exemplo bem no olho do furacão: "A questão dos megaeventos mostrava muito claramente que o processo decisório de definir quais são as prioridades, para onde vão os recursos, estava se passando entre governo e empresários. Esse gap, essa contradição, tinha num dado momento, que estourar, emergir. Porque se fosse só um modelo de decisão fechado, empresarial (a cidade mercadoria, que nós vamos vender), e de repressão total, esses modelos combinam. Agora, é um modelo de ativação por um lado e por outro, de centralização e concentração do poder [...] Esse modelo não era desmobilizador como na ditadura: ele era mobilizador e centralizador ao mesmo tempo. Isso tinha que dar errado em algum momento."128 Por isso, continua, discorda dessa cantilena do gigante que acordou: "não é verdade, as pessoas estavam ativas, estavam participando, mas infelizes e insatisfeitas”. Não foi por falta de avisos internos, um ano antes, em julho de 2012, o cientista político Adrian Gurza Lavalle, embora ressaltando a quantidade e pluralidade de instituições participativas que fazem do Brasil um caso único, e depois

128. Entrevista de Sônia Fleury concedida a Daniela Alarcon, revista ADUSP, outubro 2013. 
de relembrar que a noção de participação "nasceu atrelada a um conjunto de atores sociais que reivindicavam autonomia em relação ao Estado e às mediações políticas tradicionais", as peculiaridades de nossa transição - mais uma vez, estou muito longe de ser o único a insistir nas anomalias de nossa longa normalização depois de um regime (tradicional) de exceção - fizeram com que a participação, absorvida pelas estruturas estatais, "fosse se tornando um discurso institucional e uma categoria de operação do Estado [...] Hoje, a ideia de participação não é mais aquela carregada das energias utópicas dos anos 1960 a 1970 [...] A noção de participação e as práticas a ela associadas passaram a funcionar também como uma parte da linguagem e das instituições do Estado". ${ }^{129}$ Ainda segundo o mesmo pesquisador, não é muito difícil atinar com a inflexão na origem dessa exaustão, da sempre lastimada exaustão da antiga energia utópica: mudou o front da luta de classes, se é que não se desmanchou, e já chegou mudado na Constituinte, redefinindo, mais uma vez, o rumo da transição: "A participação tinha um claro viés popular e classista. Era a participação dos que não têm vez e, portanto, não se refere aos ricos influentes e já bem representados no poder. Esse discurso classista foi mudando, e uma nova concepção se consolidou na Constituição de 1988, porque não se podia instituir um modelo participativo feito para uma classe específica. A participação popular se tornou, então, participação cidadã."130 Abriu-se então a porta dos espaços participativos, agora instituições participativas, e sobre a rubrica da palavra "cidadã", por ela entraram os reais

129. "Na pátria da democracia 'pós-participativa'", entrevista concedida a Flavio Lobo, Le Monde Diplomatique Brasil, Jul. de 2012, p.32.

130. Ibidem, p.33. condutores da Transição. Continuemos nessa brevíssima genealogia de nossas tecnologias sociais de desmobilizar mobilizando o corpo dos governados. Cinco anos antes da radiografia que se acabou de ver em 2007, a ex-secretária executiva do Ministério da cidade (2003-2005), Ermínia Maricato, afinal admitia: "Nós batemos no teto. Nós batemos no teto da produção acadêmica. Nós batemos no teto dos movimento sociais, nós batemos no teto das estruturas democráticas". ${ }^{131}$ E como estamos vendo, batemos no teto subindo por uma escada que nós mesmos ajudamos a construir. Os degraus desta escada, não custa insistir, são formados por dispositivos sociais, um conjunto de práticas e conhecimentos cujo objetivo é governar, num sentido que se supõe útil, os gestos e os pensamentos dos homens - na formulação filosófica bem conhecida. Mais uma vez: políticas públicas é o nome genérico de um desses dispositivos. Assim sendo, é possível dizer que era esta a ironia que dava título ao artigo em que Ermínia anunciava que estava partindo para outra - "acho que precisamos reinventar a luta" -, a saber "Nunca fomos tão participativos", querendo dizer não o oposto, mas o seu avesso constitutivo, como já pudemos observar, nunca fomos tão governados, completando-se assim a escalada da fabricação da sociedade consensual em que a Transição nos converteu: nos anos 80, nunca fomos tão engajados - para glosar outro título célebre; desde o processo constituinte, nunca fomos tão participativos; com o "engajamento" das empresas socialmente responsáveis somando-se à malha cada vez mais fina da rede de políticas públicas, pode-se então concluir que nunca nos governamos tanto. Podemos pelo menos imaginar que Junho veio para abrir esse

131. "Nunca fomos tão participativos", Carta Maior, 26 de nov. de 2007. 
ferrolho. Creio que também pensam assim as pesquisadoras Anna Luiza Salles Couto e Rosângela Dias Oliveira da Paz, que acabam de coordenar uma pesquisa sobre as institucionalidades participativas existentes hoje no país, conforme contam em entrevista a Francele Cocco. Não sei se queriam ou não marcar o fosso que nos separa do que também chamam, por sua vez, "as utopias em torno da democracia participativa”, mas o fato é que principiam por uma evocação do movimento dos sanitaristas lá pelos idos de 70, cujos conselhos de saúde foram a fonte inspiradora de outros conselhos, para ir chegando aos poucos-depois de levantar os 71 conselhos e 74 conferências só no período lulista de 2003 a 2010 - à constatação nuançada o suficiente mas não menos contundente, de que existe de fato um núcleo duro no projeto do governo que não interessa abrir ao debate, para não falar em participação, numa palavra, são áreas rigorosamente blindadas. A palavrinha mágica, não por acaso, fala por si mesma: são áreas estratégicas. Já o governo do social admite quantos conselhos e conferências se quiser.

(E mesmo esse tópico está pedindo revisão, se é verdade, como também observou Sônia Fleury, que o dito "social" conheceu uma involução muito característica de todo o processo pacificador pós-ditadura. Entendido nos anos 80 como o primado dos direitos, passou por uma abordagem econômica nos anos 90 (repaginado como combate à pobreza), para se tornar agora uma "questão de segurança”, mas obviamente não mais nos moldes da República Velha, os dispositivos agora são outros. O que muda tudo, como estamos argumentando desde o início. O pesadelo de uma insurgência difusa foi sonhado na prática da pacificação armada do social, de cuja linha involutiva trata precisamente Sônia Fleury nos termos que se viu e não creio deturpar o sentido se disser que vão na mesma direção, como se pode confirmar na entrevista que estamos citando: "e isso [o fato de o social ter virado uma questão de segurança] não é pouca coisa: aqui no Rio de Janeiro, por exemplo, o secretário de assistência social é um delegado, a saúde está ligada aos bombeiros. Você tem um primado não mais do direito, mas dos órgãos coercitivos, articulando todo o social [...] essa ideia de que nós vamos inserir todo mundo dentro do Bolsa Família, e vamos inserir todo mundo consumindo, pode construir mercado, mas não constrói sociedade. A gente que está pesquisando já estava vendo esse problema. Via com muito mais dramaticidade nas favelas, onde o direito estava entre aspas, onde você tem um regime de exceção em termos de direito de se reunir, de manifestações culturais. Esse poder discricionário que foi dado à polícia na favela se mostrou sem nenhum pudor nas manifestações [...] Quando antes você levantava essas questões de desaparecimento de pessoas, da violência da polícia, todo mundo perguntava: 'e o que você quer, então, que volte o domínio do tráfico?'. Como se só existisse o domínio da coerção, de um lado ou de outro". É só ligar os pontos e concluir: "Isso não é democracia; pode ter eleição, mas democracia não é”. É pacificação permanente. E se a hipótese for plausível, não se trata apenas de revisão de todo o modelo da institucionalidade participativa, cuja erosão, como foi dito, se confunde com o seu próprio funcionamento. Com certeza será mais uma vez modulado para gerir a nova conjuntura aberta pela insurgência de Junho.)

Voltemos ao balanço de Anna Luiza e Rosângela. Os grandes projetos correm por fora, continuam, e não se trata apenas de economia ou áreas estratégicas, como ener- 
gia - tal como nos bons velhos tempos geiselianos. Não só Minha Casa Minha Vida nasceu na Casa Civil em tratativas com as sete irmãs empreiteiras que se sabe, o PAC inteiro corre por fora e por aí vamos de escuta em escuta, como se diz no jargão da autenticidade social, ora mais forte, ora menos, e sempre existem atores que berram mais alto. "Nos ocupamos demais com as institucionalidades e esquecemos das ruas". Ocorre, nas palavras das pesquisadoras, justamente apreensivas com o desafio das ruas, que o "cacife da democracia participativa é a mobilização”. Estamos vendo - espero - que a mobilização total, com a qual o capitalismo se confunde ao banalizar, amalgamando-os, guerra e trabalho, mal se distingue de uma não menos total imobilidade, ou girar em falso perpétuo, como se queira. Por isso fica a dúvida, não sei se compartilhada pelas autoras, que concluem a entrevista ainda sob o impacto do primeiro Junho, pois o segundo está a caminho, com calendário, agenda e tudo: “As próximas conferências serão o termômetro: as ruas vão conseguir ocupar conferências, 'invadi-las' com seus temas? Para além de querer mais saúde, mais e melhores políticas públicas, as ruas estão falando: nós queremos participar."132 Resta saber se as ruas e as conferências estão falando da mesma participação. Se fosse esse o caso, as revoltas de Junho teriam cumprido uma inusitada "revolução" de volta ao ponto de origem.

132. Anna Luiza Salles Couto e Rosângela Dias Oliveira da Paz, "A institucionalidade participativa”, Le Monde Diplomatique Brasil, ago. de 2013, pp.22-3.

\section{7.}

É hora de começar a olhar para o outro lado. O que não chegou a nenhum resultado. Nem chegará, talvez até nem pretenda. Aliás não é minha a distinção, mas dos autores do balanço 20 centavos: a luta contra o aumento, ao qual já nos referimos em mais de uma ocasião, e penso que não seja só deles. Como se pode ler na conclusão, "os protestos de junho deixam dois legados opostos: de um lado, a explosão de manifestações com pautas difusas e sem qualquer orientação a resultados; de outro, a luta contra o aumento conduzida pelo MPL com profundo sentido de tática e estratégia”. Os autores não têm dúvida quanto à importância relativa de ambos, ao ressaltar a dupla vitória da tendência que soube superar o principismo no qual a outra se debatia: "a dupla vitória de reduzir o custo das passagens e trazer para a centralidade do debate político a tarifa zero por meio de uma ação autônoma com uma estratégia clara, é o mais importante legado dos protestos de junho. Ele não é apenas um novo paradigma para as lutas sociais no Brasil, mas um modelo de ação que combina a política horizontalista e contracultural dos novos movimentos com um maduro sentido de estratégia"133. Quem sou eu para arbitrar? Cabe, no entanto, a dúvida: teria sido mesmo possível derrotar a maior concentração urbana de poder e dinheiro do país, como é o caso da máquina de crescimento chamada São Paulo, e ainda mais num ponto de honra midiático, onde a capitulação beira o suicídio político, sustentar a nota durante treze longos dias sem a intransigência principista da vertente indiferente a

133. Cit., último capítulo. 
resultados, não teria sido esta mesma evidência pública do inegociável o sinal de virada de todas as humilhações acumuladas? Sei que a resposta será sim, que essa dimensão "anti-política" é constitutiva do novo paradigma de luta que desfaz o consenso da paz armada - daí a necessidade do choque-, o consenso das "mediações" e representações que se multiplicam e replicam em torno de coisa nenhuma. Já ouvi até muito ativista admitir que sem a mão de gato da tática heteredoxa que se viu em ação, e que aliás ninguém encomendou, mas não surgiu do nada, o aumento da tarifa muito provavelmente não teria caído.

Recapitulemos. Os 20 centavos a menos não caíram do céu. Tampouco o céu foi tomado de assalto à maneira clássica. Foi preciso muito bloqueio, muito ônibus depredado, muita lixeira queimada, muito enfrentamento com a polícia, mas também muita assembléia de rua. Como lembrado mais uma vez, foi preciso enfim adicionar à desobediência civil uma forte dose de todas aquelas práticas que a paz armada de nossa interminável transição colocou na ilegalidade - ou manteve. Para que os 20 centavos caíssem foi preciso então profanar, nos termos de nosso visionário Sílvio Mieli - algo muito mais intolerável que as vidraças quebradas de agências bancárias e assemelhados de marca e luxo - os santuários do único monopólio que realmente importa, e pior, por gente comum, autoconvocada, monopólio cuja lei não escrita proíbe, desqualifica e demoniza "tudo o que poderia ser eficaz porque realizado diretamente. Nessa concepção de vida pública, toda e qualquer iniciativa cabe exclusivamente ao Estado, às instituições e às autoridades". Quem gritou Mais Estado! - um blog paródico gerado em Belo Horizonte abriu cadastramento para um programa Mais Vândalos! -, achava por certo que estava se contrapondo ao suposto Mais Mer- cado! da direita nas ruas, cujo Fla-Flu aliás não é assim tão raso, pois a direita leu o seu Polanyi e sabe muito bem que o mercado é uma construção política do Estado; quem gritou Mais Estado! na verdade estava mesmo era desconcertado e ressentido com tamanha ingratidão, com o rumo assumido por tais atos profanatórios de insurgência, seja qual for o conteúdo de experiência que uma tal visão venha uma hora precipitar. E por isso mesmo, tais anomalias são politicamente inassimiláveis, a depender, é claro, de como conseguirão transformar o extraordinário em quotidiano para voltar à frase programática de Maurício Carvalho, do coletivo Juntos! Mas o ponto não é este, mas sim o que restou e parece não chegar a lugar nenhum, raciocinando ainda em termos de processo e resultado. A tal pauta difusa. Ou melhor, a ameaça difusa que ficou pairando no ar, depois que o perfil da moçada baixou ao se retirar para um discreto segundo plano, evitando talvez ser pacificada antes da hora.

Não é fácil achar o outro lado. Nele, tudo é difuso: sua indignação, sua pauta, sua ameaça. E como vimos no caso do cão sem nome e dono "insurgência", nasce antes do tempo pelas artes do seu contrário. Também parece ser este o caso da expressão "ameaça difusa”. Ela pode ser encontrada, dormindo ou prestes a dar o bote, num editorial da Folha de São Paulo de 22 de julho de 2001, "Rebeldia primitiva”. O responsável pela ressurreição daquela peça do nosso museu da ideologia é o sociólogo Adalberto Cardoso, cujo artigo, onde se dá o referido registro, logo mais passamos a comentar, para não dizer abusar sem a menor cerimônia, tal o valor arqueológico do achado ${ }^{\mathbf{3 4}}$.

134. Adalberto Cardoso, "As jornadas de junho e a mercantilização da vida coletiva”, Insight/Inteligência, n. 62, jul.-ago.-set., 2013. 
Para variar, o editorialista encarregado de dar o recado da empresa que edita o jornal, passou por algum curso de sociologia, quem sabe USP, também, para variar, dando a entender que conhece o livro de Eric Hobsbawm sobre as formas arcaicas dos movimentos sociais, Rebeldes primitivos $^{\mathbf{1 3 5}}$. Não só dá a entender, mas seus temores sugerem que o compreendeu muito bem. Mesmo estando obviamente cansado de saber que não há mais banditismo social, muito menos movimentos milenaristas, no Brasil e no mundo na entrada do séc. XXI, como tampouco ainda existiam tais irrupções anacrônicas de violência pré-política no tempo em que Hobsbawm concluiu o seu livro, um sexto sentido, digamos atávico, para os "repentes de fúria", que marcaram um passado nem tão remoto assim no país, o deixou de sobreaviso. Não era para tanto, afinal o século a que Hobsbawm confiara a prova da atualidade de sua curiosidade de historiador - como escreveu, foi a consciência política que aqueles rebeldes primitivos adquiriram que tornou o séc. XX o mais revolucionário da história - acabara de morrer e ser enterrado como sinônimo de catástrofe. Mas não sua visão dual da fratura brasileira, que a década que se passara aprofundara ainda mais, quase nas suas mesmas palavras: de um lado do fosso, os amplos setores da sociedade cuja lógica de reprodução é a da desagregação social, do outro, a minoria globalizada, afluente e influente, dois mundos cada vez mais incomunicáveis entre si. E se estranhando mutuamente. No alto da pirâmide, "um Estado em crise de financiamento, em boa medida alheio à grande maioria da população, dando acesso privilegiado a minorias organizadas e eli-

135. Rio de Janeiro: Zahar, 1970 - trad. Nice Rissone. A edição original é de 1959. tes bem posicionadas" - e isto que o poder incumbente de turno desembrulhara todo o pacote conforme lhe encomendaram investidores e organismos multilaterais, verdade que eram tempos de apagão e os apoios começavam a minguar. Mas olhando para o alto desta pirâmide, "o que os diversos setores da sociedade brasileira, aos quais os frutos do desenvolvimento não chegam" avistavam não deveria ser muito diferente do que os seus ancestrais primitivos e rebeldes entendiam por Estado, "soldados e policiais, prisões, cobradores de impostos, talvez funcionários públicos"136.

Ironia dos tempos históricos à parte - um Estado inacessível, cada vez mais reduzido ao seu mínimo denominador coercitivo, e inconformismos cada vez mais “arcaizantes" -, passemos ao inventário da desagregação naquele ano de 2001. No topo da lista, um clássico dos medos urbanos de então, os morros cariocas sob o domínio de um suposto Estado paralelo, tal qual o oficial ausente, mesclando brutalidade e intimidação ao arremedo pirata de alguma provisão social. Todavia, ao editorialista esclarecido, interessa menos esta imagem inquietante porém chapada da desintegração em curso do que os termos quotidianos desse processo, a saber: as taxas endêmicas de quebra-quebras, saques e linchamentos, que só alcançam o noticiário, irrompendo em ciclos mais agudos ou frequentes, por algum motivo extraordinário, como nos casos mais recentes da seca castigando o Nordeste; a anarquia a que foi entregue Salvador nos piores dias da greve da polícia, o enésimo protesto de comunidades cariocas reagindo às arbitrariedades da polícia: dias depois, perueiros e polícia se enfrentando em Belo Horizonte. O

136. Hobsbawm, Ibidem, p.14 
panorama se completa com uma referência a dois parâmetros que permitiriam avaliar com precisão estatística o crescente embrutecimento do dia a dia na cidade de São Paulo: "na sexta-feira, outro ônibus foi incendiado. Em 2000 a Prefeitura computou 636 depredações nestes veículos de transporte de passageiros; 38 foram queimados. Como as chacinas, que somaram 53 no ano passado e mataram 185 pessoas, os ataques contra ônibus vão ganhando status de rotina paulistana”. Não sei se deliberadamente buscada ou não, essa contabilidade em duas colunas - pessoa chacinada, ônibus queimado - é um retrato de época tão revelador quanto o seu barateamento pelo registro administrativo. Seja como for, salvo a ressaltada rotina sinistra, ao contrário dos ataques aos ônibus, não há como incluir as chacinas no rol dos "protestos difusos e violentos", cuja escalada inquietava o editorialista. Sendo assim, por que entraram na conta? Os corpos acumulados dos chacinados estariam enviando algum recado? De qualquer modo o editorialista estava bem longe de ignorar - daí o bocejo cínico com que alinha os automatismos paralelos - que também se incendeiam ônibus em protesto contra a violência policial desenfreada ${ }^{\mathbf{1 3 7}}$. Ontem rotina - assinalada como quem destaca uma singularidade cultural -, hoje instituição.

Pois foi a persistência dessas ondas incendiárias que

137. "Protestos por causa de assassinatos atribuídos por parentes das vítimas à Polícia Militar foram responsáveis por cerca de um terço de ataques a ônibus na capital neste ano. Três mortes terminaram em manifestações, com a destruição de nove dos 32 queimados na cidade - média de um por dia desde que 2014 começou", O Estado de São Paulo 30 de jan. de 2013, A13. Está por certo na ponta da língua o arremate, desde que 2014 começou e 2013 ainda não terminou nem terminará tão cedo. Muita coisa ainda vai entrar na conta de Junho. Resta a dúvida: porque somente em janeiro, seis meses depois, quando então em um único mês o número de veículos queimados supera o total de casos registrados no primeiro semestre de 2013, junho incluído? despertou a imaginação do sociólogo Adalberto Cardoso, raciocinando aliás como todo mundo, diante da evidência do estopim dos protestos, só que na primeira hora, quando a grande queima de ônibus mal começava a extrapolar a rubrica do fait divers. Mas justamente não se trata de um estopim qualquer, como sabemos. E o MPL foi obviamente o primeiro a encarar o paradoxo da utopia real em chamas, aliás nem tão paradoxal assim, salvo a afinidade ancestral entranhada na imaginação do fogo entre destruição purificadora e libertação - tanto quanto o seu contrário: é só pensar no destino da Comuna de Paris segundo Zola, para não falar na mitologia wagneriana ${ }^{\mathbf{1 3 8}}$. Não é esse o terreno do MPL, mas uma "tocha gigante", como a Folha de São Paulo se refere à piromania que teria tomado conta ultimamente das ruas da capital ${ }^{139}$, sempre comove, quanto mais não seja, pelo próprio poder hipnótico do fogo. No extremo oposto, o incêndio de favelas, criminoso mesmo quando é acidental, para não falar (de novo) no Reichstag. Mas só agora o terreno da luta, e os dispositivos que o atravancam, parece óbvio, pois o transporte não é apenas ruim, é ruim há muito tempo: "as pessoas destroem os ônibus, e destroem recorrentemente os ônibus, por algum motivo, se da década de 1940 até 20013 as pessoas continuam quebrando ônibus em momentos de revolta popular, é preciso pensar por que as pessoas estão fazendo isto. E é porque aquilo é considerado por elas uma forma de opressão. É considerado algo terrível e vio-

138. Mexendo agora com fogo, seria indispensável remeter ao capítulo da tese recente de Acácio Augusto Sebastião Jr. sobre a revolta incendiária dos estudantes gregos em dezembro de 2008, Política e anti-política: anarquia contemporânea, revolta e cultura libertária, PUCSP, setembro de 2013.

139. 25 de jan. de 2013, p.C2 e C3. Publicado na manhã dos confrontos da noite daquele mesmo dia de tiros e atropelamentos. 
lento. Porque não se escolhe aleatoriamente um alvo em um quebra-quebra. Não é uma escolha aleatória. Então, se destrói o ônibus porque ele é o símbolo de um quotidiano opressor, de um quotidiano violento. E aí ganha uma força e uma capilaridade muito grande. Porque o transporte é violento e, ao mesmo tempo, muito caro"140.

Voltemos à "ameaça difusa" que deu o ar de sua graça no editorial de 2001 e retornou agora em traje de gala: como há uma década atrás, os mesmos "protestos difusos e violentos", os mesmos "repentes de fúria", sinalizando uma "escalada de intimidação" - só que agora, de tão difusa a ameaça ultrapassou a "minoria globalizada e influente" do fim de século passado e alcançou seus sócios menores, embora politicamente majoritários, os gestores autointitulados desenvolvimentistas da pacificação nacional em andamento, e momentaneamente abalada. Mas não avancemos o sinal. Um aviso de incêndio entre outros: com o ambíguo charme da rebeldia primitiva a menos, um outro editorial da mesma empresa jornalística, diante da onda incendiária de agora, depois de enumerar os mesmos indícios inquietantes de desagregação - entre os quais incluía, é bem verdade, os excessos de sua própria polícia, outro ritual, cujo exorcismo vale menos que água benta - abria com uma vinheta tipo Datena: "a depredação de patrimônio público ou privado, a título de protesto contra os mais variados problemas, tem se transformado numa perigosa e inaceitável rotina no quotidiano nacio-

140. Lucas de Oliveira, entrevista com Maria Carlotto, cit. Tampouco foi aleatória a escolha das catracas na revolta de trabalhadores na estação de trem de Francisco Morato - ou aquilo que a CPTM chama de estação: um barracão de Brasilit sobre canos de ferro, em 29 de março de 2012 analisada por Ronan no artigo já citado do Passa Palaura, "Um avanço nas revoltas de trabalhadores humilhados pela CPTM". nal"141. Entre o boletim de ocorrência e o arrazoado do juiz de vara cível, os vislumbres de Aufklärung sociológica esparsos no similar da década anterior desapareceram sem dar notícia.

Pois então. Pesquisando em julho de 2013 o termo "ônibus queimado" no site do jornal O Globo e encontrando 559 ocorrências cobrindo o período de novembro de 2011 a julho de 2013, quase uma notícia por dia sobre depredações de ônibus, Adalberto Cardoso não pensava obviamente estar descobrindo a pólvora, identificando seja um padrão naquela extensão do repertório do protesto social, seja a centralidade da mobilidade urbana na vida das pessoas, sem a qual, tudo o que a cidade promete "é vivido como privação, e no limite, como opressão”. Espírito e letra do discurso ativista, como se acabou de ver e se poderia multiplicar. Um protesto regrado portanto, que de rebeldia primitiva não tem nada: pois moradores de um extremo periférico qualquer, protestam contra enchentes queimando ônibus porque não conseguem chegar em casa, e se não depredam a ponte sobre o rio transbordado, ou um poste de iluminação, nem tampouco a própria casa ou os carros estacionados no caminho, é porque "a fúria não foi primitiva, no sentido do editorialista da Folha, não se tratou de causar danos ao patrimônio público sem mais, nem de um dia de fúria coletiva que vandaliza tudo" - tratou-se, como foi dito, de um protesto regrado ${ }^{\mathbf{1 4 2}}$.

Mas não dizia só isso, o indigitado editorialista, que embora esclarecido nem por isto estava menos guiado pelos reflexos condicionados e acumulados ao longo de nossa

141. "Onda incendiária”, Folha de São Paulo, Caderno Opinião, 28 de jan. de 2014 .

142. Adalberto Cardoso, cit. p.25. 
interminável transição pacificadora: não há conflito que um bom dispositivo social não desarme, a começar pelo sistema dito político, cuja enésima reforma - assim como se reforma incansavelmente a escola, a prisão, etc. - oferecido durante menos de 48 horas em junho passado (2013). E assim sendo, está dito e estabelecido, ontem como hoje, que o povo toca fogo em ônibus porque se trata de "uma grande massa desorganizada incapaz de acessar as instituições públicas para pressionar pelos seus interesses”, e assim, incapaz de "movimentos coesos", só pode mesmo desatinar nos repentes de fúria numa rebeldia primitiva, etc. etc. Todavia, nosso autor não saiu a campo para rebater essa panaceia desmoralizada e roída até o osso. Só as pedras de Brasília e adjacências, fingem não saber que a política meramente política faz tempo não pode mais nada salvo multiplicar seu poder de dano, sendo que a prova dos nove foi afinal produzida quando em 2002 a maioria social no Brasil finalmente tornou-se maioria política. E nada ${ }^{\mathbf{1 4 3}}$. As profanações de Junho - manifestantes dançando um

143. Obviamente, ao contrário do que pensa a metafísica clássica, esse "nada" tem mil propriedades, sobretudo na acepção brasileira do termo. Pode ser a Paz Total, como logo veremos. Pode ser também o da vida eterna de um sistema de transferências monetárias condicionadas, Providência verdadeiramente divina. Como disse, mil propriedades. N.B.: quando Chico de Oliveira lançou a tese da "irrelevância da política", na esteira de sua hipótese bem conhecida do Ornitorrinco - cuja evolução truncada não carece mais de consciência - o pessoal do CEPAT Informa (Curitiba) pediu-me que a comentasse, o que fiz nos limites de uma entrevista. "Qual política?" (Paulo Arantes, Extinção, cit. pp.285-292). Quanto à outra política, cuja extinção a Paz Total a caminho anuncia e persegue, a política como "dimensão primordial de encaminhamento das expectativas humanas", o nervo mesmo da mobilização social das "pessoas comuns", Greg Grandin, de quem estou emprestando a definição, sustenta que tal foi o objetivo primordial do arrastão aterrorizante que recobriu o continente desde a deposição de Jacobo Arbenz na Guatemala em 1954, arrastão que nos alcançou em 1964 e prosseguiu Cone Sul adentro até retornar nos anos 80 à América Central dos derradeiros genocídios daquelas mais de três décadas de Contrainssurgência. Ver neste volume o ensaio em resposta à pergunta: O que resta da ditadura?, "1964, o ano que não terminou", na ed. original, pp.217-218. samba rasgado na cobertura do Congresso Nacional - não são portanto repentes de fúria de rebeldes primitivos. $\mathrm{O}$ que resta saber é se os atos profanatórios da insurgência de Junho mudaram o vento que faz crescer essas ondas incendiárias. Os entrincheirados - para adotar de vez uma das categorias de James Holston - compreensivelmente, ora sustentam a nota da escalada insurgente-criminosa, e seu contraveneno de ilegalidades oficiais, ora banalizam o ciclo atual de protestos violentos, mais uma onda longa e rotineira tomando, no entanto, o cuidado de situá-la num patamar mais elevado e duradouro de violências urbanas a serem administradas por mais uma rodada de providências securitárias.

No ponto a que chegamos, o Estado "prefere realmente ser julgado por seus inimigos a sê-lo por seus êxitos inexistentes". Toda política antiterrorista segue este preceito enunciado por Guy Débord nos Comentários de 1988, como relembra Anselm Jappe, num dos ensaios de Crédito à morte: A decomposição do capitalismo e suas críticas $^{\mathbf{1 4 4}}$. Poderia ter remetido diretamente à fonte. A intermediação de Jappe não é fortuita. O leitor que porventura tenha procurado o artigo abre-te Sésamo de Sílvio Mieli, não só poderá avaliar as liberdades que tomei ao comentá-lo, mas poderá verificar o quanto sua visão de um tempo no qual as Revoluções que conhecemos na Modernidade darão lugar a sublevações em que o corpo social se insurgirá através de uma série de atos profanatórios, não digo que seja tributária, mas por assim dizer entrou em estado de alerta graças à leitura de um ensaio de Anselm Jappe, ao qual remete o leitor aludindo brevemente ao seu argumento, "Violência, mas para quê?" incluído no livro

144. São Paulo: Hedra, 2013, trad. Robson de Oliveira, p.74. 
citado. Uma amostra do raciocínio histórico que o alertou para o fato de que o fenômeno Black Bloc nos acontecimentos de junho não era trivial pede sem dúvida citação por extenso. A esta altura podemos economizar a recapitulação das últimas três décadas de colapso administrado, que não devemos confundir com a sociedade "totalmente administrada", como os Frankfurtianos denominavam os míticos 30 anos gloriosos da ordem fordista do pós-guerra, cujo caráter de saída de emergência e fuga para a frente rumo ao cataclismo nuclear que animava a "correria" das sociedades afluentes jamais os enganou, dois desastres administrados emendando um no outro, porém distintos e responsável, tal diferença no tempo do mundo, pelas narrativas estilizadas em alternância, ora sobre as ruínas do futuro que não chegou, ora em torno da restauração da saída de emergência de anteontem, em que todos os embarcados pareciam se dar bem. Portanto, no pé em que estão as coisas, ficará cada vez mais difícil para os governados se deixarem governar como no tempo em que havia "valor" para distribuir e algum poder para repartir na margem, ao mesmo tempo em que o Estado anuncia que é pegar ou largar, nenhuma mudança é mais possível, chegamos a uma engenharia institucional tão acabada e consolidada, que ao Estado não resta mais nada senão oferecer aos seus cidadão cada vez mais "proteção", agora finalmente compreendida como segurança humana total, da segurança sanitária a operações de manutenção da Paz e imposição da Lei, passando pelas prestações monetárias continuadas e diretas, em suma, em graus variados mas contínuos, todos congenitamente vulneráveis e carecidos de proteção - estou parafraseando um tanto livremente, por isto volto ao ponto. Então: ficará cada vez mais difícil encontrar cidadãos aquiescentes. "Não se trata de justi- ficar ou, ao contrário, de condenar a difusão de práticas classificadas 'ilegais' e o recurso que o Estado define como 'violência'. Pode-se simplesmente dizer uma coisa: vai ser muito difícil que os atos de contestação, que não deixarão de aumentar nos próximos anos, respeitem os parâmetros da 'legalidade' concebidos precisamente no objetivo de condená-los à ineficácia"145. Ato contínuo "as questões de legitimidade, mais que de legalidade, vão ser colocadas de uma forma renovada. É possível que vejamos novamente acusados que, em vez de sempre proclamar sua inocência em termos de lei, defenderão diante dos tribunais com orgulho o que fizeram e aceitarão as consequências". Como outrora "a grande maioria dos revolucionários históricos" que "entravam e saíam da prisão sem emoções desmesuradas"? Podemos duvidar da propriedade da lembrança, salvo pelo contraste: é que para os rebeldes primitivos de hoje, o futuro não é mais o que era para os revolucionários históricos. "Atos de sabotagem, portanto. E dá impressão de que é isso o que as autoridades temem acima de tudo. Eficácia da sabotagem: se hoje os cultivos de plantas que contêm organismos geneticamente modificados estão parcialmente suspensos na França e se uma boa parte da opinião pública os recusa, isso ocorre graças aos 'ceifadores voluntários', e não por causa de abaixo-assinados". Dito isso, e muito mais que não relatei, entramos no capítulo dos avisos de incêndio. Por exemplo: se uma guerra civil de verdade estourar, "não é difícil imaginar quem sejam os primeiros a serem acordados em plena noite e colados ao muro". Outro, surpreendentemente convencional: "Sentimentos de rejeição engendrados pelo

145. Ibidem, p.75. O artigo que estamos citando "Violência, mas para quê?" foi publicado originalmente na revista Lignes, 2009. 
mundo de hoje estão muito mais próximos do ódio sem objeto e dificilmente podem ser incluídos numa 'política' (?), qualquer que seja”. Na mesma linha: "é possível odiar o existente em nome de algo ainda pior". Sem dúvida. Como também não se pode duvidar desta outra evidência histórica: "admirar a violência e o ódio enquanto tais ajudará o sistema capitalista a descarregar a fúria de suas vítimas em bodes expiatórios”. Ou não tão histórica assim, para nós a outra novidade de Junho, à qual voltaremos mais à frente: ainda incipientes, mas não por muito tempo, milícias de direita se apresentaram em plena Av. Paulista, e atuaram segundo um script que ainda não sabemos decifrar sem o auxílio de rótulos que nos remetam em sonho às ruas da República de Weimar, ou à Roma dos anos 20. Outro axioma igualmente irrefutável: ao longo de uma crise que já dura 30 anos, muitas coisas se degradaram, e desse apodrecimento não escapam também a violência e a ilegalidade. Desse juízo segue-se a pergunta que encerra o ensaio de Jappe, e Sílvio Mieli transcreve por considerá-la mais do que pertinente no atual cenário das turbulências brasileiras: "É muito provável que a couraça da 'legalidade' não demore a se estilhaçar, e não há o que lamentar. Mas nem todas as razões que empurram à violência são boas. Talvez a violência só devesse encontrar-se nas mãos das pessoas sem ódio e sem ressentimento. Mas será isso possível?"146

Com efeito. Schiller achava que não. Mas não só ele, de fato um dos primeiros a levantar o argumento, recorrente desde então. A Revolução Francesa escalou até o máximo do Terror, não porque sua violência de qualquer modo incontornável caiu em mãos erradas, mas porque

146. Ibidem, p. 85 . não havia, nem poderia haver "pessoas sem ódio e ressentimento" numa sociedade como a do Antigo Regime, corroída por séculos de opressão e consequente e irreversível mutilação daqueles a quem assujeitou do berço ao túmulo. Daí seu projeto de uma Educação Estética da Humanidade, um verdadeiro programa de desbarbarização avant la lettre (viriam outros depois, particularmente depois do apocalipse nazi e, sem muita surpresa, também ancorados na Educação depois da Catástrofe), do qual brotariam os sujeitos emancipados que no limite acabariam por tornar a reviravolta revolucionária dispensável. Tantas voltas para retornar ao paradoxo velho de guerra da Revolução Burguesa, segundo o Idealismo Alemão? Uma geração imaginando expedientes especulativos de obter os fins economizando os meios. Não é por certo o caso de nosso amigo Jappe - violência só nas mãos de quem tem amor para dar é coisa de Ong carioca. Sarcasmo à parte, o impasse não é menos impressionante, afinal o moinho de gastar gente, operando hoje em escala planetária, é uma tremenda máquina de gerar ainda mais humilhação social. Segundo o psicólogo José Moura Gonçalves Filho, a humilhação é o mais radical e desestabilizador dos sofrimentos proletários. "A humilhação é golpe ou é frequentemente sentida como um golpe iminente [...], o sentimento de uma pancada torna-se compulsivo, vira pressentimento"147. Noutro ensaio deste mesmo volume ${ }^{\mathbf{1 4 8}}$, procurei situar melhor essa visão original de José Moura na cadeia de argumentos vinculando o cortejo de explosões urbanas na França - outra rotina, a primeira e maior delas - a

147. "Humilhação: um problema político em psicologia”, Psicologia USP, vol.9 n.12, 1998.

148. "Alarme de incêndio no gueto francês". 
situações de humilhação armadas através de um sistema sofisticado de "desrespeito institucional". É como se quebra o sentimento de ter direitos, de sorte que ocorrendo o milagre de um emprego qualquer, melhor trabalhar sem levantar os olhos. Mal podemos imaginar o Himalaia de humilhações ressentidas pelos milhões na fila de espera à boca dos guichês de ingresso num mundo afluente que não para de encolher. Mas parece que a Teoria Crítica também não consegue imaginar a pequena humilhação suplementar que lhes inflige a cada linha de generalidades acerca da compulsão fetichista que os domina, afinal querem entrar e participar da festa, que é sempre a do consumo - um outro desrespeito institucional. Por este trilho, a equação "subversão inteligente" e sofrimento social certamente não fechará nunca, pelo menos antes de virar gestão de política pública. Há um século e meio atrás nem tudo estava perdido. Sobre o pano de fundo do estado de sítio moral no qual se encontrava mergulhada a burguesia francesa - ruminando a novidade da má consciência que lhe envenenava a vida, primeiro por ter massacrado os operários parisienses sublevados em junho de 1848, logo depois por ter não menos sordidamente abdicado do poder político em favor de um golpe de estado que no entanto pedira aos céus -, seus ideólogos justamente inventaram um sentimento novo do mundo, o Ressentimento e sua constelação de paixões tristes, e como se isto não bastasse, atribuíram a fonte social desse mais sombrio dos afetos negativos ao desejo de vingança dos impotentes, que a julgar pelo seu próprio interior forrado de rancores, projetavam na miséria moral da classe que haviam destroçado: todo proleta humilhado e ofendido é mesmo um poço de ódio e ressentimento. Pois sobre essa floresta assassina de clichês, cuja fortuna filosófica se conhece, levantou-se o verso lu- minoso de Baudelaire: Sans haine et sans remords. Faz tempo, não estão mais disponíveis sujeitos assim. Quanto ao pote de mágoas que transbordou em Junho, com sorte ainda atinemos com o seu destino, antes que se esvazie de novo, tantos são os interessados em sugá-lo e transformá-lo numa cesta de produtos, candidaturas no topo da lista.

Voltemos ao editorial de 2001 sobra a rebeldia primitiva fermentando no Brasil contemporâneo. Ali também um padrão é seguido faz algum tempo. Por mais difusas que fossem as ameaças sinalizadas pelos indícios de desintegração alinhados pelo editorialista, havia uma cara nova em cena. E uma novidade tanto para a esquerda, movimentista ou institucional, quanto para direita propriamente dita. Recapitulemos mais uma vez. Um ano antes, no primeiro de maio de 2000, ativistas de um novo tipo, inspirados pela Ação Global dos Povos, são presos depois de ousarem se manifestar em plena Av. Paulista. Ao voltarem à mesma Avenida em 20 de abril do ano seguinte, em sintonia com os protestos de Quebec no mesmo dia contra a Cúpula das Américas, já são mais de dois mil e duramente reprimidos, outra surpresa política que à época o assim denominado campo popular deixou passar sem maiores estremecimentos, e olhe que no Primeiro Fórum Social Mundial, em Porto Alegre, poucos meses antes, o MST e a Confédération Paysanne se juntaram para destruir um campo de transgênicos da multinacional Monsanto. Por fim, dois dias antes da matéria editorial que estamos tomando como baliza, dia 20 de julho, cinco mil ativistas protestavam de novo em São Paulo, na mesma avenida a um só tempo totem e tabu, enquanto em Gênova perto de trezentos mil manifestantes entravam em choque com um aparato de força policial desproporcional, para dizer o menos, que viria a ser a norma nas batalhas de rua vin- 
douras, a começar pelo assassinato de um militante por um tiro a queima roupa, Carlo Giuliani. No dia seguinte, a Folha de São Paulo incluiria os protestos antiglobalização e sua "disposição para o confronto físico" no pacote da ameaça difusa, cujo amplo espectro se viu. A ação direta e autônoma estreava assim como "rebeldia primitiva", com direito ao tratamento reservado aos primitivos, como aliás o são todos os que desconhecem as virtudes da mediação e se entregam ao domínio de suas pulsões imediatistas. A amarração estava assim feita no mesmo pacote da violência pré-política. Embora personagem recém-chegado, era um entre outros. Com o passar do tempo, aliás desapercebido, o amálgama foi caminhando para o centro da ameaça, que continuava a mesma, difusa como sempre, só que mais intensa a cada rodada. Até que Junho mostrou retrospectivamente que um padrão se estabelecera, como vimos na abertura dos nossos trabalhos: o processo de pacificação nacional encontra-se periodicamente sob ataque - como todo ato falho, o mais recente revela todo um cenário só aparentemente familiar: somos alvo de uma "guerra psicológica adversa" -, que se apresentam na forma de ondas, a de agora é novamente incendiária, afinal se trata de uma rotina, e como bandidos populares primitivos, e primitivos não tão populares, como ativistas de todo calibre, mas sobretudo os encapuzados, botam todos fogo em ônibus... quando não saqueiam ou lincham.

O padrão dessas racionalizações, como sugerido acima, de fato é duplo, porém, trivializado ou assoprando o fogo, sempre se encontra um jeito de arrastar para o centro do redemoinho o inimigo político a ser neutralizado. No calor dos 50 ônibus incendiados só no mês de janeiro na Grande São Paulo, o jornalista Jânio de Freitas botou tudo na conta de uma presumida "regra brasileira das ondas"
- na verdade, nem tão presumida assim, pois se trata de um dos mais veneráveis lugares-comuns acerca do caráter nacional brasileiro, o fôlego curto de uma proverbial veleidade em toda sorte de iniciativa, aliás falta de iniciativa, consistente e duradoura -, sosseguem, portanto, toda essa violência suburbana dará em nada. Eis a regra: “os incidentes podem até surpreender no surgimento, mas também surpreenderão no murchar repentino, quando ascendiam com aparência indomável". ${ }^{149}$ Quer dizer, gastei meu latim, e o leitor, seu tempo, caso tenha chegado até aqui. Junho? Fogo de palha. A ordem pública é de fato uma desordem, porém mais aparentada aos ilegalismos populares, que o lendário Major Vidigal controlava com mão de ferro no Rio de Janeiro do tempo do Rei Dom João VI, do que a caminho de inverossímil estado caótico de insegurança generalizada, mera projeção paranoide da impressão de fato inquietante disseminada pelos incidentes que afinal apenas ressaltam a quão arraigada é a "desordem da ordem pública". Até onde chegou a pegada da tradição crítica brasileira! As ondas vêm e voltam, a praia é sempre a mesma, "mesmo o Black bloc do ano passado". Podemos respirar? Tanto faz, o recado é outro, a incivilidade dos mascarados surfa na mesma onda dos arrastões de praia e shopping, assim como as ocupações de Sem Teto também entram na onda de incêndios por encomenda de bandidos. "No momento, por sinal, eles [os bandidos] estão criando uma onda, esta contra as unidades da PM instaladas em várias favelas: votam a infiltrar-se e criam conflitos para restabelecer-se”. Estava demorando. Para morrer na praia, é claro, em vários outros estados maiores e menores desordens urbanas vão se sucedendo com a

149. "Um pouco de vida", Folha de São Paulo, 30 de jan. de 2014, A9. 
mesma cara: "ataques a ônibus, interrupção de estradas e baderna urbana”. Como o nome indica, Junho entra nesta última rubrica, para variar envolto pela mesma névoa dos tiros nas UPPs. É por essas e outras, que tais ondas, por mais estilizadas como o eterno recomeço de um mar de Valéry, por vezes encrespam e ganham a força hostil de um real oponente.

Força oponente, para ser mais exato. Assim o Ministério da Defesa, em portaria de 19 de dezembro de 2013, denominou os demônios de junho, camuflando-os, entretanto, num cipoal bem conhecido de ameaças difusas e confusas, que remontam por certo àquele mesmo fundo, ao que parece inesgotável, de seres primitivos que de tempos em tempos se rebelam em dias de fúria. Por remotos que sejam não são menos estreitos os laços de família entre o artigo de há pouco e o Manual de Garantia da Lei e da Ordem que define normas para o engajamento das Forças Armadas no papel de polícia, se as forças de segurança nacional não funcionarem ${ }^{150}$, manual que só pode ser obviamente tão direto como um cabo de esquadra, mas que nada impede de receber uma maquiagem digamos, mais "dialética", depois da faxina a que foi submetido, flexibilizando a Lei até o limite de sua suspensão dentro da Lei - fazer, em suma, um uso tático da Lei - e chamar de "desordem da ordem pública" a Ordem encarregado de garantir - e como não se trata nem de longe de garantismo, seria mais apropriado falar em gerenciar, mais exatamente calibrar a insegurança. Tirante o jargão jurídico-administrativo da caserna, é fácil reconhecer o coquetel de

150. Ver a reportagem de Wilson Tosta, “Após crítica, Defesa faz mudanças em manual”, O Estado de São Paulo, 6 de fevereiro de 2014, A9. Ver ainda do mesmo repórter matéria anterior de 22 de jan. de 2014, A5. ameaças a serem enfrentadas por mais este dispositivo contrainsurgente, só que desta vez nada extemporâneo, embora pareça ressuscitar quinquilharias do tempo em que forças ocultas adotavam estratégias de tensão para melhor dar o bote - como na Itália dos anos 70, para não ficarmos só com a prata da casa. Antes do expurgo, a pedidos, das expressões mais cruas, entre elas a mais dramática "forças oponentes", o documento listava entre as tais forças oponentes, além dos movimentos sociais e demais organizações, que com razão estrilaram ante tamanha falta de tato, "organizações criminosas, quadrilhas de traficantes de drogas, contrabandistas de armas e munições [...]" etc. - cuja promoção política a categoria de oponente parece ter surpreendido menos-, igualmente "pessoas, grupos de pessoas ou organizações atuando na forma de segmentos autônomos, ou infiltrados em movimentos, entidades, instituições, organizações [...] provocando ou instigando ações radicais ou violentas", sem esquecer dos "indivíduos ou grupos que utilizam métodos violentos para a imposição da vontade própria em função da ausência das forças de segurança pública policial”. No capítulo das "Principais Ameaças" a serem enfrentadas, caíram as seguintes frases mais polemicas, como se diz: "ações contra a realização de pleitos eleitorais", "bloqueio de vias públicas", "depredação do patrimônio publico e privado", "distúrbios urbanos" (parece que só colunista prefere "baderna"), "paralisação de serviços críticos ou essenciais à população", "sabotagem nos locais de grandes eventos", "saques". Também sumiram referencias a operações psicológicas (não se sabe se a pedido da Presidência da República) e a uso da Comunicação Social para conquista e manutenção do apoio da população. Advertia-se, noutro parágrafo recauchutado, que o menor in- 
cidente poderia "ser explorado pelas forças oponentes ou pela mídia (sic)", abastecendo a "propaganda adversa à atuação das Forças Armadas”. Admitamos que o Manual MD33-M-10 tenha ignorado a "regra brasileira das ondas" - não confiou no tino sociológico de nosso conselheiro Ayres, porém ligou os mesmos pontos cujo desenho há poucos meses ainda podia surpreender. De qualquer modo, ainda no capítulo Ameaças Difusas/Pauta Difusa, não deixa de ser preciosa a candura do lapso freudiano de apostila, a denegação que confirma por antecipação: o Ministério negou que o objetivo do Manual fosse dar condições à tropa de atuar durante a Copa do Mundo; tampouco seria o caso de tomar a iniciativa como uma resposta às manifestações de Junho. Nem eles sabem o que fazem, mas fazem assim mesmo, por reflexo. Caso soubessem o que é consciência, o certo seria dizer: não é nem de longe só por isso. Copa e Junho, e mais adiante Olimpíadas, são apenas aplicativos de ocasião, a verdade verdadeira é que o processo de pacificação nacional está ingressando num estágio de ajuste da segurança interna à condição de potência emergente arcando em sua ascensão com um lastro social negativo, embora inventivamente bem administrado. Se fosse só para prender e arrebentar, não carecia de mais uma cartilha. Trata-se de impor a paz, e mantê-la. Neste sentido, a Nota valorosa lançada pelo PCB assim que a indigitada portaria transpirou - "Editado o Ato Institucional número 1 da era petista" -, se equivoca, inclusive ao atribuí-la aos "setores mais retrógrados da sociedade", nem acertaria se visasse os "mais avançados", o metro não é mais esse. Tampouco ajuda recorrer à Constituição Cidadã de 1988, pois segundo o artigo 142 cabe às Forças Armadas a "garantia dos poderes constitucionais, e por iniciativa destes, da lei e da ordem". Como costuma lem- brar um estudioso das instituições coercitivas como Jorge Zaverucha, há muitas "ordens" na Constituição - interna e internacional, constitucional, pública, social e econômica - e de todas elas, em boa lógica, as Forças Armadas são garantidoras, cabendo na prática àquelas mesmas Forças decidirem quando houve violação da lei e da ordem, já que o texto constitucional não define quem nem quando a lei e a ordem foram violadas, concluindo que, tudo somado, cabe às Forças Armadas "o poder soberano e constitucional de suspender a validade do ordenamento jurídico, colocando-se legalmente fora da lei". ${ }^{151}$

No final das contas, maquiado ou não, estamos diante de um manual de instruções para a condução de um processo de guerra interna não declarada. Outro despropósito? Sim e não. Danial Biral, do grupo Advogados Ativistas, conta que de junho a novembro, só em São Paulo, 373 pessoas estão respondendo a processos investigativos ligados às manifestações. É um processo claro de criminalização de direitos assegurados pela Constituição, diz ele. Acrescentando que num evento recente, o ex-presidente do Supremo Tribunal Federal, César Peluso, interpelado sobre a violência "policial” nas manifestações, teria declarado, sem pestanejar, "em nenhuma guerra os países respeitam as Convenções de Genebra e vivemos de fato uma guerra interna no país"152. Até onde sei, passou batido e mesmo que não tivesse, o espantoso é que alguém ainda se espante com a declaração, e sobretudo não saiba que é disso mes-

151. Jorge Zaverucha, "Relações civil-militares: o legado autoritário da Constituição brasileira de 1988”, em Edson Teles e Vladimir Safatle (orgs.) O que resta da ditadura: a exceção brasileira. pp.48-49.

152. Vinicius Souza e Maria Eugenia Sá, “Fantasmas da ditadura”, Caros Amigos, dez. de 2013, p.25. 
mo que se trata. Disso mesmo, mas exatamente o quê? O Meretíssimo se exprimiu na língua morta de outro tempo. Para ser exato, nos termos de um antigo regime da guerra, e sua continuação política. Os tempos agora são humanitários, por isso muita gente que não usar a faixa de pedestres vai morrer, como ouvi não faz muito um ativista já proscrito e banido das manifestações, dizer serenamente num seminário ${ }^{153}$. Ficaremos na mesma, apelando para a Constituição. Assim como o obsoleto golpe de estado tornou-se constitucional, para uma declaração de guerra interna basta uma portaria de um ministério a rigor decorativo, apesar do nome de gente grande, Ministério da Defesa como no Hemisfério Norte. Está claro que para o tempo para o encontro do qual já estamos a caminho, precisaremos de muito mais advogados ativistas, defensores populares, magistrados para a democracia e o que mais vier, embora saibamos que há quase três décadas de democracia, a democracia rotineiramente chacina nas periferias e nos presídios, para não falar na sempiterna pistolagem à serviço do Partido da Terra ${ }^{154}$, a cuja tradição, os novos tempos agregaram o controle direto do ter-

153. Numa das tantas cenas desconcertantes do filme Cronicamente inviável (2001), de Sérgio Bianchi, uma dondoca fantasiada de socióloga tucana atropela um menino de rua. Não está se desculpando, ao dizer aos brados que o infeliz atravessara fora da faixa, na verdade sai do carro passando uma descompostura, dirigindo-se à pequena audiência de curiosos que se formara à sua roda (seminário sobre as novas incivilidades?), na vítima, seus familiares, educadores, e o que mais for, pelo descaso na educação que não houve acerca das regras de trânsito.

154. A história do Brasil sempre foi uma história de camponeses ameaçados e assassinados. Para eles, a guerra interna é permanente e dispensa manual de instruções. Partido da Terra é o título do livro de Alceu Luis Castilho, um levantamento sistemático e exaustivo de como os "políticos conquistaram o território brasileiro", e vice-versa, como o nosso sistema político-partidário é ocupado sistematicamente pelos donos do território. O capítulo da guerra é o último, sobre os escravizados, mortos e ameaçados. São Paulo: Contexto, 2012. ritório pelas empresas que tocam megaprojetos, controle exercido inclusive pela mobilização de pequenos exércitos privados, à maneira das antigas companhias mercantilistas do século XVII, comerciais porém datadas de poderes de governo sobre seus territórios de negócios. ${ }^{155}$

A transição, ou redemocratização sempre em vias de se consolidar, como se queira, não corre mais pelo velho

155. Não precisamos recorrer ao exemplo clássico desse revival mercantilista, o "governo" de corporações como Halliburton e Bechtel sobre porções do território iraquiano, então reconquistado em 2003. Ver Paulo Arantes, "A viagem redonda do capitalismo de acesso", Extinção (cit.), pp.176-178. À sombra dos megaprojetos e megaeventos essa fusão de poder capitalista e poder territorialista opera por aqui numa escala jamais vista - a rigor ela é a expressão integral do Brasil contemporâneo - tanto nos confins da Amazônia, nos portos secos e propriamente ditos, mas antes de tudo na cidade que Carlos Vainer vem chamando de Cidade da Exceção, a cidade-empresa sob governo direto do capital, e não se trata apenas do Rio de Janeiro Cidade Olímpica. Além de seu artigo bem conhecido, "A cidade de exceção: reflexões a partir do Rio de Janeiro", ver ainda sua mais recente entrevista, "Carlos Vainer: Rio promove "limpeza urbana' e será mais desigual em 2016”, por Dario de Negreiros, Viomundo, 30 de janeiro de 2014. Em resumo, a cidade de exceção é uma cidade-empresa planejada para funcionar estrategicamente como uma empresa num mercado internacional de cidades que vendem localização para as grandes corporações que circulam pelo mundo. E como (falsa) empresa atuando numa situação de mercado politicamente construída (uma situação de mercado sem mercadorias reais: por qualquer ângulo que a observemos, a cidade enquanto tal não é uma mercadoria) precisa ser inteiramente despolitizada como qualquer empresa, e sua legislação específica, indefinidamente derrogada, flexibilizada, contornada. Seu governo se confunde com uma sequência de Operações Urbanas (que por sua vez integram o elenco das intervenções contemporâneas) impulsionadas pelos famigerados "instrumentos", quase todos da família das Parcerias Público-Privadas. A última geração delas, fechando o pacote da mão baixa do capital no comando das cidades, inclui uma inovação espantosa, a "concessão urbanística", outro instrumento, mediante o qual o poder de desapropriação do Estado é transferido ao setor privado, de sorte que um cartel de empresas, ao "ganhar" uma concessão para reurbanizar um bairro torna-se de fato seu dono, podendo desapropriar para investir em megaempreendimentos imobiliários nesse território, que certamente precisará ser altamente protegido e vigiado, resposta armada incluída. Ver a respeito dessas patologias normalizadas, a extensa reportagem de Fabrício Muriana e Sabrina Duran, no âmbito do projeto Arquitetura da Gentrificação, "PPP de habitação: parceria entre governo estadual de São Paulo e capital imobiliário ameaça até classe média”. É por essas e por outras que o discurso clássico das mediações passou desta para melhor faz tempo. Não há mais "mediações" nas cidades, todas as ligações são diretas. 
trilho regulado pela exceção soberana que o defunto liberalismo histórico recriou para uso próprio ao desentranhá-la da Razão de Estado que o Absolutismo inventou. A exceção de hoje confunde-se com o próprio governo. Um emaranhado de violações ad hoc, estritamente administrativo. Um sistema ritual de comandos indevassáveis, como vimos, se fui convincente, a racionalidade política que hoje governa o mundo - como outrora o sistema de racionalizações ideado por Max Weber - é bem outra. Nela se exprime uma outra razão, uma Razão Pacificadora. Sendo o seu governo, por isso mesmo, um governo armado, em todos os sentidos. Uma Razão Humanitária, como prefere dizer Didier Fassin, centrada, porém, nesta denominação, no governo das vidas precárias, vai se expandindo pelo conjunto da vida social, que por sua vez se apresenta cada vez mais como um cenário de traumatismos e reparações ${ }^{\mathbf{1 5 6}}$. Mas "governadas" e não pura e simplesmente reprimidas. Num presente essencialmente humanitário, novamente na acepção que inicialmente lhe deu Eyal Weiszman, não espanta que essa Razão Pacificadora careça de cooperação armada para operar - e não se trata tão-somente de intervenções humanitárias, elas próprias transes dramáticos de um mesmo paradigma dominante -, e operar num ambiente social e político muito além do pas de deux envelhecido Democracia e Ditadura. Vivemos fora do museu onde estes trastes podem ser visitados e apreciados na sua justa medida: Liberalismo (político ou econômico), Social-Democracia, Democracia Participativa (secção últimas aquisições), sem falar num outro museu, o da Revolução, a ser frequentado mais assiduamente, é verdade. É onde vivemos, numa ordem

156. Didier Fassin, La raison humanitaire, Paris: Gallimard, 2010. que poderia ser redescrita como a-democrática - como sugerido por Wendy Brown -, onde não faz mais o menor sentido contrapor a democracia liberal de nossos avós ao fantasma de um autoritarismo neoliberal. Enquanto a esquerda não se livrar deste entulho nada terá a dizer a não ser chorar o leite derramado, que aliás nunca foi seu. Dizendo isso, estou apenas acompanhando o argumento final de Dardot e Laval157, no qual relembram que a esquerda, para bem ou para mal, nunca se apresentou com uma alternativa propriamente sua. Sempre parasitou formas alheias de comando e gestão, quando não gerou formações monstruosas ao fundir num só bloco, porém com funções intercambiáveis, administração dos homens e governo das coisas - governo dos homens e administração das coisas corrigiria Saint Simon. Seja como for, pelo caminho trilhado até agora não chegaremos nunca à pedra filosofal. A primeira providência é bem simples: apenas olhar e ver que governos governam, o seu reino é o da necessidade, a segurança humana num reino de vulnerabilidades, e se é assim, não faz o menor sentido - malgrado dois séculos de ilusões - enxertar nesse reino, congenitamente securitário - nele todo mundo, cedo ou tarde, se desincumbirá de algum trabalho sujo, que não é trabalho por acaso, planejará efeitos colaterais inevitáveis etc. - as nossas arvorezinhas da liberdade. Em bom português, esperar de governos que governem como se não fossem governos, mas blocos progressistas na cabine de comando, e como tais periodicamente plebiscitados: visto das alturas de tal cabine, por exemplo, travar o processo de acumulação é atentar contra a segurança do território. Não estou falando de nuvens, nem arengando na sacristia depois da

157. La nouvelle raison du monde, cit. pp.469-475. 
missa. Como sugerido em mais de uma ocasião ao longo destas páginas, Junho foi antes de tudo sobre isso: como somos governados, como nos governamos, e como agora não queremos mais saber disso. Salvo, é claro, o secular progressismo brasileiro, justamente porque há governo, sempre uma benção numa sociedade que precisa dar certo, pois sempre haverá um resíduo inorgânico a ser absorvido pela máquina civilizatória. Ingratidão? Está certo o Ministro. Visto do alto, é sempre isto que se vê. No dia 24 de janeiro (2014), no Fórum Social em Porto Alegre, o Ministro Secretário-geral da Presidência da República declarou que houve perplexidade no governo federal, e até um sentimento de "ingratidão" em relação aos manifestantes de junho de 2013: "nós ficamos perplexos", esclarecendo que o "nós" abrangia governo e "movimentos sociais tradicionais". Retratou-se no dia seguinte, afirmando que fora mal compreendido ao dizer "fizemos tanto para esta gente e agora eles se levantam contra nós”. Não é preciso recorrer às costas largas de nossas raízes coloniais. Não é mero ressentimento da gente de mando desapontada com a legião de clientes mal agradecidos. Mas como essa multidão de ingratos governou-se e foi governada até agora?

Por uma política de terapia social, responderia Edson Teles, pesquisador e militante veterano na luta dos familiares de mortos e desaparecidos pela Ditadura ${ }^{158}$. Desde que, oficialmente com a Constituição de 1988, a assistên-

158. Cito de acordo com os textos que tenho à mão, pois o autor se manifestou muitas vezes a respeito desse modelo de fusão jurídica-normalizadora que geralmente atende pelo nome de Estado Democrático de Direito. Por exemplo, "Democracia e estado de exceção: o conceito de ação na filosofia política contemporânea por meio do discurso dos direitos humanos", até onde sei ainda inédito, e "Democracia, segurança pública e coragem para agir na política", publicado originalmente no Blog da Boitempo e incluído no livro da mesma editora Occupy: movimentos de protestos que tomaram as ruas (São Paulo: Boitempo, 2012), pp.75-82. cia social deixou de ser filantropia e configurou-se como um modo essencial de lidar com o sofrimento de populações empobrecidas, fragilizadas e carentes de toda sorte de atenção, foi se consolidando no Brasil a ideia verdadeiramente consensual segundo a qual, sendo Democracia e Estado de Direito uma coisa só, a gradativa submissão do político ao ordenamento jurídico nada mais seria do que a expressão conforme de uma prática social fundamentada no discurso dos direitos humanos, de sorte que "os danos sofridos pelo sujeito político são objetivados por meio do tratamento da falta, como políticas positivas de reconhecimento e diminuição da injustiça. O sujeito ativo da democracia é identificado com a parte da sociedade capaz de se envolver com a solução do problema [...] em lugar da ação política, os novos atores sociais são instados a fomentar, no teatro da fabricação de resultados, a governança do sofrimento, através de uma mudança social contabilizada nos índices de desenvolvimento humano". No centro do nosso presente humanitário encontra-se precisamente mas não só - o processo de dissolução da última utopia - como foi caracterizado o front dos Direitos Humanos em seu período épico de confronto com a violência exterminista e desaparecedora inerente ao poder soberano enquanto tal -, para ser exato, seu processo de paulatina conversão de verdadeira antipolítica, em sua acepção libertária, em... política pública ${ }^{159}$. Conversão evidentemente dramática para os ativistas herdeiros dessa tradição militante que salvou vidas incontáveis no auge do Terror Branco na América Latina, por exemplo. Não deve ter sido fácil para nosso autor precisar reconhecer a presença dessa buro-

159. Ver Samual Moyn, The Last Utopia: Human Rights in History (Cambridge: The Belknap Press, 2010). 
crática banalização do derradeiro horizonte utópico nas engrenagens das atuais tecnologias de controle social. "Participando do consenso da política contemporânea, o discurso dos direitos humanos legitima, paradoxalmente, tanto a resistência do individuo frente às violências sofridas quanto às políticas dos Estados nacionais, os maiores violadores de direitos. Desta forma, o militante e o ministro, o sem-terra e as forças de segurança, o destituído e a grande mídia são seus usuários”. E como já vimos, a ideia básica deste discurso, eminentemente terapêutico, é a de que estamos cercados de vítimas por todos os lados e que só serão assistidas graças ao império da lei distribuída pelos seus tribunais, um fazer em que tudo se negocia e barganha por consenso - o resto é “politização", da qual Edson dá como exemplo, a carta do governo brasileiro ao Conselho de Direitos Humanos da ONU (19/07/2010), "na qual se propõe a negociação com os regimes autoritários com o intuito de evitar a "politização'”. Num quadro como esse, de boa governança dos indicadores de sofrimento social, rebelar-se só mesmo por ingratidão. E além do mais, por milagre, sendo impossível por princípio resistir a um tal consenso fabricado em torno da unanimidade dos direitos humanos. Pois esse milagre ameaçou acontecer em Junho.

Sinal de que há processos de subjetivação que as malhas dessa rede estão deixando passar. Uma preciosa descoberta sociológica de Regina Magalhães de Souza - a mesma "desconstrutora" do Discurso do Protagonismo Juvenil, à qual o leitor já foi apresentado - oferece algumas indicações a respeito. Ensinando sociologia por vontade própria numa gigantesca e monstruosa UniEsquina, Regina viu seus alunos - na maioria trabalhadores pobres, no geral moradores das mais remotas periferias - descobrin- do aos poucos a existência de uma coisa chamada "sociedade" -, que segundo o consenso de há pouco, igualmente interpelado por Edson Teles, não existiria mais, apenas uma massa atomizada de vidas vulneráveis e individualizadas, e a rede de programas e socorristas que os gerencia, por um lado, e do outro, o lado ativo dos que "se viram", encarando, nas palavras de nossa autora, sua atuação social apenas como indivíduos exclusivamente responsáveis pela solução de seus problemas através da negociação com outros indivíduos cuidando igualmente de seus interesses particulares - dando-se conta ao mesmo tempo que esta mesma recém descoberta sociedade "lhes exige muito mas não lhes oferece as condições de realizarem o que foi exigido". Numa palavra, começaram a pensar. E a "reinterpretar sua posição no mundo, percebendo as conexões entre situações, experiências individuais e conjuntura histórica e social"160. Ora, segundo Regina, isso "só foi possível porque os discursos do poder contemporâneo, que prescrevem um tipo de relação entre individuo e sociedade não haviam atingido esse segmento sui generis da sociedade. Pessoas pobres, com o dinheiro contado, tinham acesso apenas parcial ao mercado de consumo, e ao modo de pensar propagados pela indústria cultural. Eram adultas, já haviam aprendido a resistir aos apelos da propaganda, não usavam roupas de grife, não navegavam pela internet. Moradores da periferia, mas que, por algum motivo, se mantiveram afastados dos movimentos sociais urbanos de reivindicação de direitos e dos sindicatos e dos partidos. Mas também não eram tão pobres a

160. Regina Magalhães de Souza, “Trabalhadores vão à faculdade: notas para uma investigação sobre sujeitos que voltam a estudar", capítulo de um livro coletivo organizado por Nilton Ota e Luciano Pereira, ainda em andamento. 
ponto de preencherem os requisitos para se tornarem os beneficiários de programas sociais, não se tornando objeto, portanto, do discurso das políticas públicas governamentais e não governamentais. Ou seja, parece que essas pessoas não foram atingidas ou totalmente atingidas [...] pelo discurso do protagonismo que nega a existência da sociedade apresentada como um aglomerado de indivíduos particulares em atividade e em negociação entre si [...] relativamente distantes do individualismo, padronização e coisificação promovidos pela indústria cultural, e sem participar, quer das 'tradicionais', quer das 'novas formas de política', essas pessoas não se transformaram em objetos de discurso do poder hegemônico na atualidade, o que lhes proporcionou inusitada abertura ao conhecimento e ao exercício do pensamento". Pois Regina encontrou muitos deles nas ruas de Junho, que prontamente reconheceram a professora que os ajudara a redescobrir a sociedade escamoteada pelas tecnologias sociais de gestão e controle. Desses últimos peixes fora da rede (Até quando? Planilhas e editais para apanhá-los já devem estar sendo desenhadas) certamente não se poderá dizer que protestavam por pura ingratidão. Quanto ao milagre que os fizera voltar a pensar, alguma coisa ficamos sabendo agora. Duplo milagre, se incluirmos na conta a contribuição de um clássico, Durkheim, que reinventou sua disciplina no intuito de apaziguar as paixões políticas que periodicamente empurravam a Franca para o abismo da guerra social. "Falando muito simploriamente, creio que a massa dos manifestantes era de indivíduos desamparados e sem discurso mas que por isso mesmo foram capazes de perceber o caráter subalterno e de segunda categoria de sua inserção na sociedade, no mercado de trabalho, no mercado de consumo, no nível superior de ensino, na vida da me- trópole [...] Os desamparados, sem-discurso, 'excluídos do interior' (Bourdieu), descobriram que coletivamente podem manifestar-se contra uma sociedade que tudo exige e nada cumpre"161. Se não soubermos ou não pudermos contar com eles para a tarefa política da geração que vem, nada feito.

(Continua)
161. Regina Magalhães de Souza, "Impressões sobre os manifestantes de junho na cidade de São Paulo”, inédito. 


\section{Postscriptum}

Na identificação do lado sombrio de Junho, nenhum cuidado será demais. Não sei se Celso Frederico cuidou de tomar essa precaução ao escrever que “o 'demoníaco' deu o ar de sua graça nas manifestações de junho, quando depredações, vandalismo, e roubo de lojas aproximaram grupos punks, Black blocs, policiais infiltrados, ladrões e adeptos da ação direta." ${ }^{162}$ Não sei se o amálgama é uma forma peculiar de conhecimento - embora a enumeração caótica em poesia, seja-, mas nesse caso particular ele está no ar enevoado de Junho como uma vontade difusa de encontrar logo o mínimo denominador comum entre aquelas três categorias de coisas que compunham a estranha ontologia do antigo Secretário de Defesa Donald Rumsfeld: as coisas que nós sabemos que sabemos; as que nós sabemos que não sabemos e, as mais inquietantes, as que nós não sabemos que não sabemos. Como estas últimas lhe tiravam o sono, acordava atirando a esmo. Espero não cair na tentação de cometer o amálgama simétrico, ao evocar a hoje antiga teoria argentina dos "dois demônios", predominante nos primeiros anos da redemocratização sob Alfonsín. Para voltar à vida normal, pregava a doutrina que inspirou também os julgamentos paralelos, dos militares e dos líderes guerrilheiros sobreviventes, era preciso que a Argentina exorcizasse os demônios do passado, um passado de violência política contínua e generalizada, como se sabe, porém convenientemente recortado para acomodar uma revisão da carnificina recente como o resultado do enfrentamento entre dois grupos, no limite socialmente

162. “Da periferia ao centro: cultura e política em tempos pós-modernos”, cit. p.17. marginais, identificados com a violência, os militares golpistas repressores e a esquerda radical, e por isso mesmo, igualmente terrorista. Descartava-se assim "a crise mais profunda na história argentina como uma mera sucessão de episódios sem sentido nos quais o país fora vitimado por gangues rivais de sequestradores e assassinos vindos aparentemente do nada"163. Com as Forças Armadas ignominiosamente derrotadas na Guerra das Malvinas, essa fantasia de uma reconciliação nacional indolor tinha endereço certo, os violentos que quiseram mudar tudo, esses sim os verdadeiros possessos, e possuídos pelo demônio das ideias abstratas, cuja passagem ao ato sempre despertou os outros endemoniados que desejam manter tudo igual. Essa doutrina andou passeando por aqui, pregando igualmente a equivalência entre as duas violências que teriam tresloucadamente medido forças numa guerra particular. Mas não poderia pegar para valer, sem a sua contrapartida jurídica. Ao contrário da Argentina, por aqui os demônios fardados continuam à solta. Para não falar nos potentados e hierarcas que desceram aos infernos para convocá-los. Amálgama infeliz à parte, os demônios de agora - exorcizados por toda uma nova era de paz civil - abandonaram o corpo da nação para se refugiar numa outra manada de porcos, a que tomou conta das ruas de Junho, ao invés de cumprirem à risca seu destino evangélico, atirando-se de um precipício urbano qualquer para se afogar nas águas de algum jardim pantanal. Para que o exorcismo surta efeito, é preciso que o demônio diga o seu nome. Na parábola bem conhecida do Novo Testamento,

163. Tulio Halperin Dongi, apud Luis Roniger e Mario Sznajder, O legado de violações dos direitos humanos no cone sul (São Paul: Perspectiva, 2004), p.280. 
o Possesso de Gerassa teria respondido: "Legião é o meu nome, porque somos inumeráveis". Nas últimas páginas de Os demônios, de Dostoievski, o pai do principal deles, o ridículo liberal ocidentalizado de turno, cuja pantomima ideológica, se traz prestígio para os notáveis do distrito, não engana ninguém, muito menos sua protetora rica, da qual não é mais do que um agregado de casaca, evoca a Parábola, cujo teor o título do romance condensa e ilustra com o paroxismo final de incêndio, assassinatos e patifarias variadas, pelas mãos dos herdeiros pseudo-tudo que se possa imaginar de caricato em matéria de conspiração e ideias iconoclastas, tão artificialmente enxertadas e manuseadas com a inépcia de vigaristas como as da geração anterior de falastrões inócuos. O truque de Dostoievski era pôr para gesticular, e quebrar, todo aquele elenco de détraqués num cenário impossível, porém ligeiramente deslocado para revelar o fundo falso de todo o progressismo europeu, entre outras ideias alucinadas, pelo prisma russo, é claro. Desse folhetim genial e sangrento, tirou-se muita bobagem depois do 11 de setembro. Mesmo assim, Toni Negri e Michael Hardt cometeram a imprudência de colher justamente nesse imbróglio todo uma paráfrase incontornável da parábola que lhes interessava por sua vez comentar para melhor ilustrar o seu conceito de Multidão como "multiplicidade de singularidades que não pode encontrar unidade representativa em nenhum sentido"164. Não menos imprudente o autor do presente comentário sobre Junho, numa hora (11 de fevereiro de 2014) em que os porcos endemoniados não só incendeiam, depredam e saqueiam, como agora matam. Essa morte trágica de um

164. Michael Hardt e Antonio Negri, Multidão (Rio de Janeiro: Record, 2005, trad. Clóvis Marques), pp.186-189. jornalista foi a gota d'água na qual nos afogaremos todos. Daqui para frente, haverá muita morte acidental de um anarquista, e não será comédia. Embora sem saber se o que nos espera varrerá tudo o que foi escrito até aqui para a lata de lixo dos ornamentos filosóficos, continuemos. Não se trata de uma questão metafísica a ser disputada entre doutrinários qualificados, um diálogo platônico sobre o Uno e o Múltiplo, por exemplo, ou um capítulo da Ciência da Lógica sobre o lugar da particularidade entre o universal abstrato e as singularidades avulsas, mas não é menos verdade que o turbilhão terminológico dos dois autores incriminados nos arrasta para estas altas paragens da especulação. Por outro lado, por mais que os autores insistam que o conceito de Multidão é um conceito de classe, e que esta é determinada pela luta, ninguém acredita. Tanto melhor, no fundo a teoria não importa, no sentido de representação ou cópia conforme do mundo. Ou por outra, o que aparece aqui travestido na roupagem de um conceito teórico seria melhor descrito como expressão de uma prática antagonista de insubordinação diante de um tipo específico de comando, de preferência emanado de um poder soberano, a que nos habituamos chamar governo. Não importa o recheio ontológico ou sociológico com que levamos o conceito de Multidão ao forno, o que de fato está chocando e enfurecendo, é o poder coletivo exibido por muitos corpos juntos na rua, demonstrando ser o mais efetivo instrumento de oposição, e pior ainda, sem clamar por um chefe - e não só aqui, essa praga está se alastrando pelo mundo. Capaz de agir em comum sem ser governada, desafia não só o Estado que necessita agora de um povo unido em torno da pátria de chuteiras, mas igualmente os partidos que precisam da massa de eleito- 
res-consumidores organizados por nichos de demanda, bem como os movimentos e organizações sociais cujos cadastros definham se o público alvo fica muito arisco, e o Capital enfim, por tudo o que se disse somado ao zelo indispensável aos envolvidos na procura de um bem escasso chamado emprego. Pois essa legião sem nome começou a mostrar a cara em Junho. Mas por que demoníaca?

(13 de dezembro de 2013 - 11 de fevereiro de 2014)

\section{Aula pública: Tarifa zero e mobilização popular}

Em 27 de junho de 2013, a convite do Movimento Passe Livre (MPL), Paulo Arantes participou de uma aula pública defronte à sede da Prefeitura de São Paulo.

Link do vídeo:

https://www.youtube.com/watch?v=JDE28pongK8

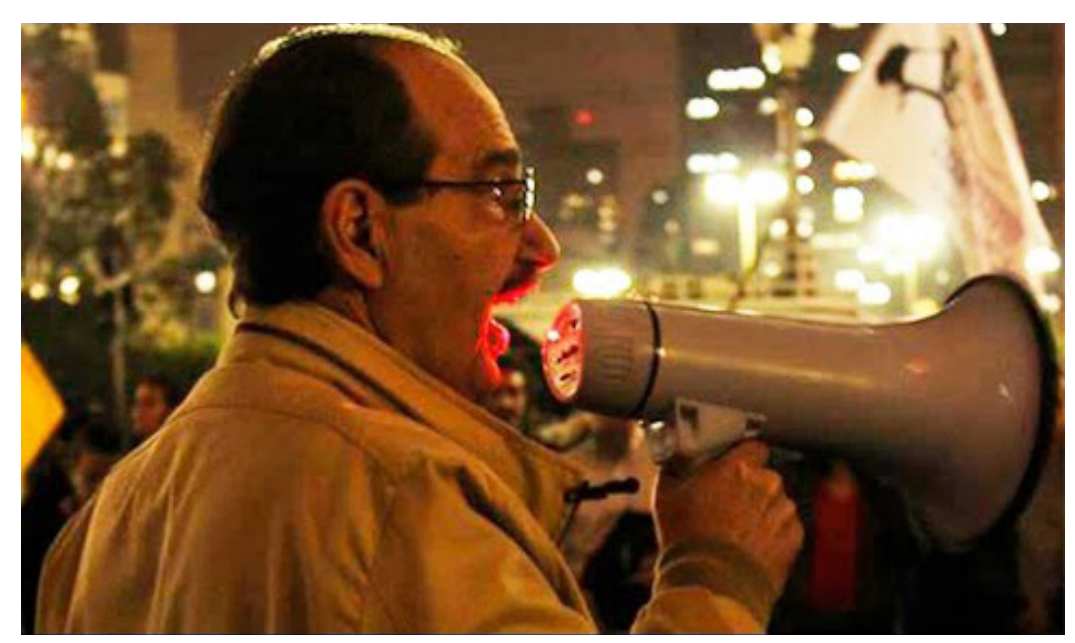

Depois do microfone falhar, a aula seguiu com megafone em mãos. 


\section{Transcrição adaptada da aula pública}

Vou me propor a responder a duas perguntas a respeito do que está acontecendo no país nessas últimas duas semanas. Como disse alguém do mainstream - e portanto suspeito - trata-se da vitória popular mais rápida e expressiva que se viu no país. Como se explica, então, como em uma semana um milhão de pessoas foi às ruas? Esta é a primeira questão. E resposta usual é: "foram as redes sociais que amplificaram um protesto minúsculo, sem elas não seria possível". Mesmo um ideólogo da teoria da sociedade em rede como Manuel Castells admite que um manifesto em rede social não leva ninguém à rua. Para ele, seria necessário, antes, que ele encontre um ambiente de insatisfação pública e mobilize imagens e palavras que correspondem a isso. Esta resposta, no entanto, não deixa de ser insatisfatória pois, de início, a insatisfação pública é uma obviedade, não há imagens nem palavras que correspondem a ela. Voltaremos a isso adiante.

A segunda questão diz respeito ao mote dessa enorme mobilização, uma metáfora extraída do hino nacional, "o gigante adormecido em berço esplêndido...”. Trata-se do conhecido lema do grande despertar, que reaparece ciclicamente na história. Pois bem, se "o gigante acordou", cabe nos perguntar com o que sonhava ele nos vinte anos em que esteve mergulhado em um sono profundo?

\section{A revolução não será tuitada}

Para responder à primeira questão, retomo o artigo Small change: why the revolution will not be tweeted [A revolução não será tuitada], escrito por Malcom Gladwell, em 2010, dois meses antes da primavera árabe, e muito antes dos indignados espanhóis e assemelhados. Nele, o jornalista conta uma história que recapitula o maior movimento de massas norte americano do século XX: o movimento por Direitos Civis, iniciado pelos negros do sul do país.

Em fevereiro de 1960, numa cidade do interior da Carolina do Norte, quatro estudantes negros resolveram ir a uma lanchonete de uma loja de departamento e se sentar em um local reservado aos brancos - o contexto, claro, é de uma sociedade extremamente segregacionista, para citar apenas uma de suas patologias. Sem serem atendidos, ficam até o fechamento da lanchonete, neste primeiro dia, e voltam logo cedo no dia seguinte. À medida em que passavam os dias aumentava o número de pessoas, negras e brancas, em torno desse espetáculo cujo desfecho ainda estava indefinido. Por um lado, aumentava a violência e as ameaças de linchamento, por outro, aumentava também o número de comitês e caravanas de negros e apoiadores que chegavam de outras cidades do país. Resultado: em dez dias, foram mobilizadas 30.000 pessoas em uma cidade de 50.000 habitantes. Isto, lembra o jornalista, em uma sociedade em que não havia Facebook, Twitter, emails, nem nada dessa parafernália que supostamente mudará o mundo. Simplesmente a notícia correu! 


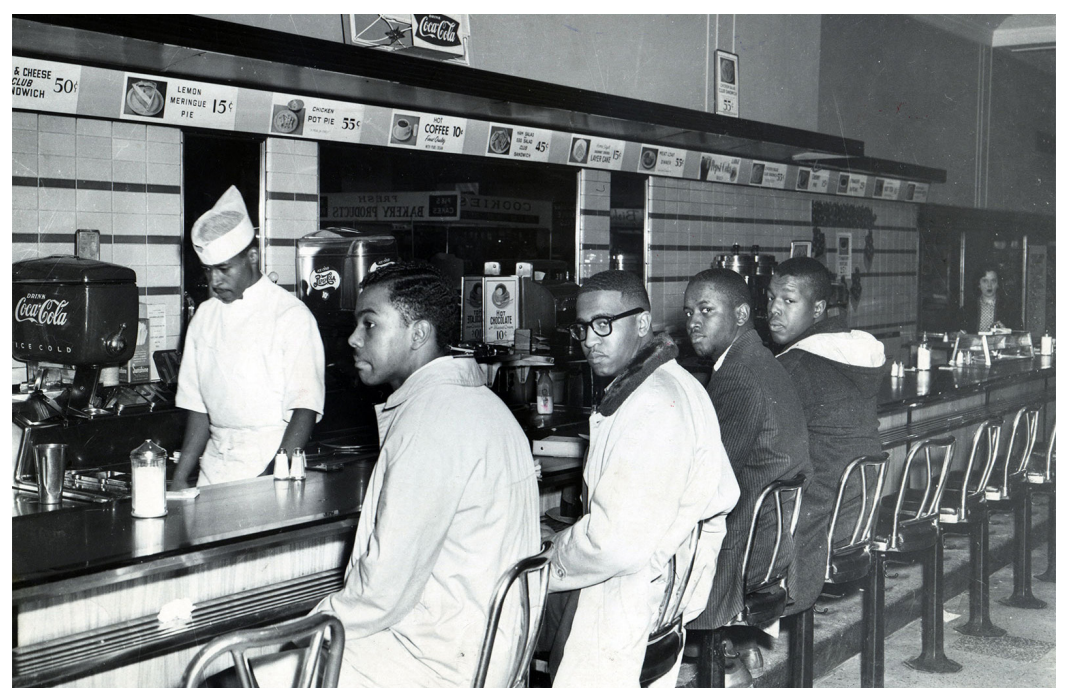

Primeiro Sit-In na lanchonete da loja de departamentos Woolswoths em Greensboro, em 1960.

Analisando o conjunto de casos que compuseram essa febre do Sit-In que contagiou todo o sul dos Estados Unidos, abrangendo diversas estratégias de intervenção política, o jornalista conclui que só o que ele chama de vínculos fortes entre pessoas seria capaz de impulsionar movimentos ativistas de alto risco. E desafiar as leis e costumes segregacionistas do sul dos Estados Unidos envolve altíssimo risco. Muito pior do que cassetete de polícia, a ameaça é de linchamento, e por parte de uma direita organizada e extremamente violenta. A disposição pessoal necessária nesse tipo de ativismo só seria mobilizada com vínculos reais, cara a cara. No caso do movimento negro nos EUA, sustentado pela amizade dos quatro jovens de Greensboro, e de fundo por uma grande coalizão comunitária, organizada principalmente em torno de igrejas e que articulava um projeto estratégico. Ou seja, vínculos que não são, fundamentalmente, aqueles em jogo nas redes sociais.

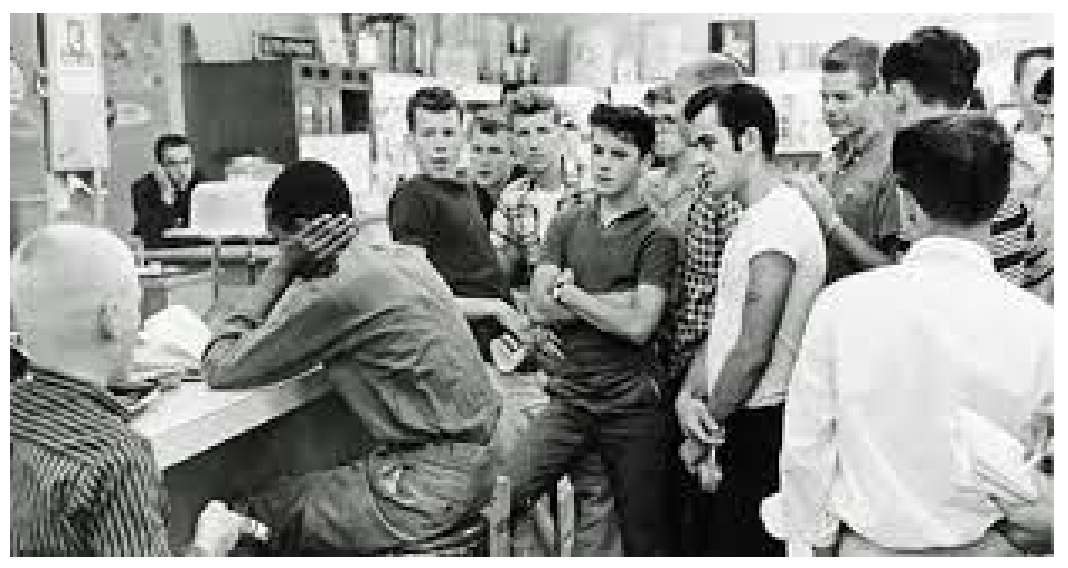

Supremacistas brancos procuram intimidar o movimento, que não parou de crescer e se tornou um marco na história do ativismo.

Outro exemplo ilustrativo, dadas as ressalvas históricas, é o das Brigadas Vermelhas na Itália nos anos 70. O levantamento feito neste caso indica que $70 \%$ dos recrutados tinha ao menos um grande amigo já filiado à organização. Do mesmo modo, podemos nos perguntar como ruiu em tão pouco tempo a Alemanha Oriental - e em um contexto em que $87 \%$ da população sequer tinha telefone! A mobilização organizava-se em torno de encontros semanais em frente a uma igreja em Leipzig e a lógica era a mesma: diziam, "eu vou porque sei que há um 'amigo crítico' meu ali" (amigo crítico era o nome dado a um conhecido que era crítico ao regime). Assim, o que quero dizer é que encontramos, invariavelmente, no ativismo de alto risco um forte traço de camaradagem - e camarada aparece aqui como transposição política da figura do amigo.

\section{Dois limiares}

Sobre as "jornadas de junho" brasileiras, pode-se afirmar que tivemos dois limiares transpostos. O primeiro sendo 
o desta disposição política que parece ter ficado varrida da memória política brasileira nos últimos vinte anos: amigos cimentados numa causa. É possível conceber, no âmago dessas manifestações, a multiplicação de coletivos em que esse vínculo forte para correr riscos reais tenha sido efetivamente mobilizado. Os riscos sendo a hostilidade da opinião pública e os perigos de uma sociedade disposta ao linchamento e ao apoio à repressão, como aconteceu no Pinheirinho e na USP recentemente.

O segundo limiar transposto, diz respeito à ideia de manifestação. Desmontou-se, praticamente, o mito pós-ditadura segundo o qual vivemos em um estado democrático de direito. O dito Estado Democrático de Direito, que traduz-se no Brasil como "estado oligárquico de direito", vale apenas para cima, pois "para baixo" tem-se apenas o direito penal e social. Neste quadro, a política é confinada ao que chamo de "chiqueirinho" do ordenamento jurídico: tolera-se o direito de livre manifestação, desde que dentro dos limites banalizados e rotinizados do local e hora marcados. Isto aconteceu porque os doutrinários da moral e cívica foram obrigados a aceitar a legitimidade das manifestações - entre outros motivos, até para não perder audiência!

Um exemplo clássico disto no Brasil contemporâneo é o MST. É somente essa característica de camaradagem que explica porque ele ainda resiste há 25 anos. O cenário que o MST enfrenta quando reivindica suas pautas é extremamente violento. Se há alto risco em alguma manifestação, é a deles. Não é possível mobilizar frente a jagunços, delegados, ameaça constante de despejo - em especial no caso do MTST - simplesmente com um evento via Facebook são companheiros de longa data que estão juntos desde os acampamentos na beira de estradas.

\section{O sono do gigante}

Quanto à segunda questão, seguramente alguns psicanalistas - sem sequer fazer uma sessão de análise com algum dos milhares de manifestantes - irão logo concluir que país voltou a sonhar. Minha sugestão aqui, para todos esses coletivos mobilizados pesquisarem: com o que sonhava o povo brasileiro nos vinte anos em que esteve mergulhado em um sono profundo? O que passou pela sua mente e espírito, o que estava represado e não se sabia, ou que de repente veio à tona?

Um ponto de partida para essa reflexão é a distinção entre o sonho noturno e o diurno. No noturno, pensamos para trás - no inconsciente não existe tempo, ele é sempre contemporâneo: não existe passado nem presente. É no sonho diurno que pensamos para frente. Esse "sonhar acordado" é chamado na linguagem coloquial brasileira de devaneio. Trata-se do escape ou descolamento ocasional em relação à realidade sem o qual enlouqueceríamos.

É esta, aliás, a própria definição da experiência literária. Uma suspensão do garrote da realidade nos transporta a uma outra esfera em que, por meio das balizas da trama ficcional, a imaginação reorganiza a existência. Após este percurso voltamos revigorados à realidade e com nova imaginação - quem leu Balzac em seu tempo, por exemplo, certamente viu a Paris de 1830, antes da revolução de 1848, com outros olhos. O prazer da literatura é justamente essa nova visão. O devaneio, o sonho acordado, é, assim - que me perdoem os surrealistas - nada menos do que o fundamento de todas as utopias.

A questão central que fica diz respeito à analogia entre esse devaneio coletivo e o vínculo forte do ativismo. 
E onde mais esse vínculo ativista poderia encontrar os milhares de adormecidos - hipnotizados, durante os últimos vinte anos, por líderes carismáticos - em sua multiplicidade de devaneios, senão no transporte coletivo? O sonhar acordado, esse breve respiro do inferno da jornada de trabalho, que pode abranger desde o namoro e a amizade às contas e a imaginação de fantásticos mundos imaginários, se dá, tipicamente, no transporte coletivo. Esse devaneio, que acontece em meio às duas horas de ida e duas de volta (para ficar no caso de São Paulo) e prefigura e exponencializa as miseráveis condições de trabalho da metrópole, pode aparecer sob a forma de uma lembrança, um causo, uma piada... às vezes acontece em voz alta e pode até se transformar em conversa. Essa conversa é perfeitamente politizável. O que acontece nesse devaneio, que afinal deflagrou o que vimos, é produto de um sofrimento social profundamente ligado ao mundo do trabalho. Mais do que recuperar palavras de ordem ideológicas, categorizando classes e posições políticas, é isto que precisamos decifrar.

\section{Perguntas:}

Do ponto de vista da organização social, o que se pode aprender com o MPL, antes, depois e durante um ato?

Bom, para responder, vocês me obrigam a refazer a apologia que fiz ao MPL, mas seria isso que disse: o significado de correr riscos altos através de um vínculo que não é o de "rede", é pessoal. Como organização horizontal, o MPL tem, em relação ao partido, tudo menos o ônus. É semelhante o caso do movimento negro, em que a organização não era mediada por partidos, mas sim em torno de igre- jas e comitês estratégicos. Esses dias um jornalista escreveu no Estadão - em tom de brincadeira, mas que mostra como as pessoas "vêem longe" - que para quebrar o movimento bastava colocar alguém do MPL na secretaria dos transportes. Claro, acalmaria os ânimos até as próximas eleições e daí o movimento já estaria extinto. Vejam, o vínculo de amizade é substituído pelo "gestor" o que diminui a disposição de enfrentar riscos e, por sua vez, enfraquece o vínculo.Temos muito a aprender com eles, mas nada a copiar. Assim como o MST, devemos apenas tomá-lo como inspiração.

E sobre as propostas feitas pela presidenta este mês de pacto social, plebiscito, e reforma política?

Ouço falar de pacto social desde o fim da ditadura. Mais precisamente, pacto "entre os parceiros sociais", isto é, entre Estado, população e o patronato. Na Europa sempre é um pacto entre esses três parceiros, por exemplo, e já vimos a meleca que deu. Não só é discurso de gestor, pois parte do princípio de reinserir o patológico no normal, como não faz mais sentido. O pacto está ruindo e a presidenta está propondo uma reedição desse mesmo pacto: reinserir todos dentro do estado, os sem terra, o agronegócio, o violador dos direitos humanos, a defensoria dos direitos humanos etc... Esse pacto explodiu agora, e é preciso reestabelecer o nexo político perdido que, para mim, está no sofrimento social.

Há um grande trabalho de repolitização pela frente. Há um grande despertar e a sociedade acorda explicitamente polarizada, e aparece uma nova direita com a qual não estamos acostumados a lidar. Mas "Pacto", "reforma política"? Não, desse mato não sai mais absolutamente 
nenhum coelho. É aspirar a um sistema que ruiu na Europa: ruiu na Espanha, na Itália produziu Berlusconi, está ruindo na França, no mundo árabe nunca teve... Não funciona mais nem para o capital! Temos uma outra sociedade plantada e não sabemos o que fazer.

Bem, vou falar sobre o meu devaneio - de gabinete, vale dizer. Imaginem uma cidade de 50 mil habitantes, uma cidade pequena. 30 mil saem às ruas, entram na prefeitura e tiram de lá o prefeito e os vereadoes a pontapés. Começam a pôr ordem na casa: poder popular. Ou seja, outra reformulação de organização da vida. Se em 15 dias você tem 5 comunas, dali mais alguns já são 100: aí começa a ter uma outra conversa política, poder popular urbano. Isso é um devaneio, obviamente.

Foi só a questão dos transportes que colocou todas essas pessoas nas ruas?

Olha, é o abc materialista (me desculpem, sou da velha guarda): a centralidade do transporte afeta a circulação, ponto. Afeta a força de trabalho se deslocando ao local em que será explorada. Agora, é a primeira vez desde o fim da ditadura em que estradas são bloqueadas sem nenhuma repressão policial. Eu ficaria com a pulga atrás da orelha - olha, será que está sendo consentido? Bloquear estradas em um momento de colapso de infra-estrutura, com a safra bloqueada nos portos superlotados é coisa da maior gravidade, prestem atenção. Basta lembrar do caso da França há 3 anos atrás, bloqueio de refinarias de petróleo, ou dos piqueteiros argentinos há 15 anos, para pensar a repercussão.

Mas não tenho conselho estratégico, nem é esse meu papel. Não posso incitar nada nesse momento em que sabemos o que é a polícia militar, o que significa a administração armada da vida social... Essa democracia da chacina não é feita à revelia da sociedade, mas com seu consentimento. A sociedade é um horror, ela está despertando, mas não sabemos os fantasmas que foram cultivados ao longo desses vinte anos. Podem aparecer coisas horrorosas, como pode aparecer também uma chama libertária, que eu confio que apareça.

Transcrição resumida realizada pelo Blog da Boitempo. Publicada originalmente em https://blogdaboitempo. com.br/2013/07/03/tarifa-zero-e-mobilizacao-popular/

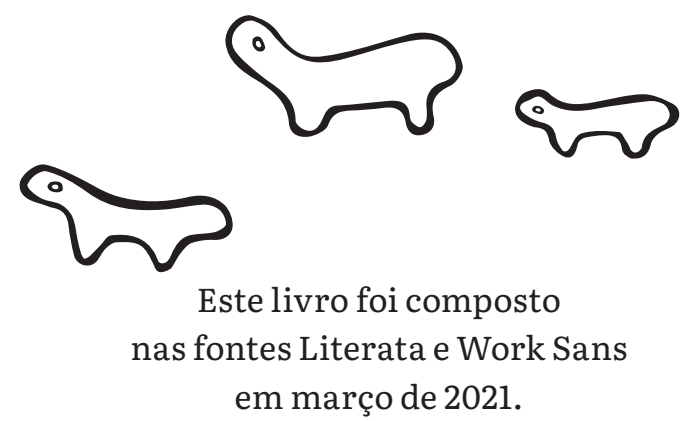

169 